\title{
High-Performance Ducts in Hot-Dry Climates
}

Marc Hoeschele, Rick Chitwood, Alea German, and Elizabeth Weitzel Alliance for Residential Building Innovation 


\title{
NOTICE
}

This report was prepared as an account of work sponsored by an agency of the United States government. Neither the United States government nor any agency thereof, nor any of their employees, subcontractors, or affiliated partners makes any warranty, express or implied, or assumes any legal liability or responsibility for the accuracy, completeness, or usefulness of any information, apparatus, product, or process disclosed, or represents that its use would not infringe privately owned rights. Reference herein to any specific commercial product, process, or service by trade name, trademark, manufacturer, or otherwise does not necessarily constitute or imply its endorsement, recommendation, or favoring by the United States government or any agency thereof. The views and opinions of authors expressed herein do not necessarily state or reflect those of the United States government or any agency thereof.

Available electronically at http://www.osti.gov/scitech

Available for a processing fee to U.S. Department of Energy and its contractors, in paper, from:

\author{
U.S. Department of Energy \\ Office of Scientific and Technical Information \\ P.O. Box 62 \\ Oak Ridge, TN 37831-0062 \\ phone: 865.576 .8401 \\ fax: 865.576 .5728 \\ email: mailto:reports@adonis.osti.gov
}

Available for sale to the public, in paper, from:

U.S. Department of Commerce

National Technical Information Service

5285 Port Royal Road

Springfield, VA 22161

phone: 800.553 .6847

fax: 703.605.6900

email: orders@ntis.fedworld.gov

online ordering: http://www.ntis.gov/ordering.htm 


\section{High-Performance Ducts in Hot-Dry Climates}

Prepared for:

The National Renewable Energy Laboratory

On behalf of the U.S. Department of Energy's Building America Program

Office of Energy Efficiency and Renewable Energy

15013 Denver West Parkway

Golden, CO 80401

NREL Contract No. DE-AC36-08GO28308

Prepared by:

Marc Hoeschele, Rick Chitwood, Alea German, and Elizabeth Weitzel

Alliance for Residential Building Innovation

Davis Energy Group, Team Lead

123 C Street

Davis, CA 95616

NREL Technical Monitor: Stacey Rothgeb

Prepared under Subcontract No. KNDJ-0-40340-04

July 2015 
The work presented in this report does not represent performance of any product relative to regulated minimum efficiency requirements.

The laboratory and/or field sites used for this work are not certified rating test facilities. The conditions and methods under which products were characterized for this work differ from standard rating conditions, as described.

Because the methods and conditions differ, the reported results are not comparable to rated product performance and should only be used to estimate performance under the measured conditions. 


\section{Contents}

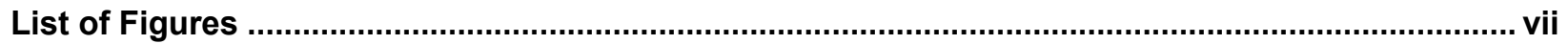

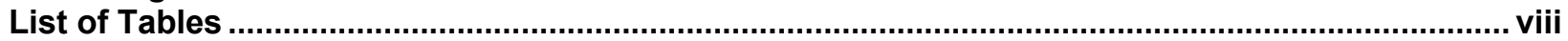

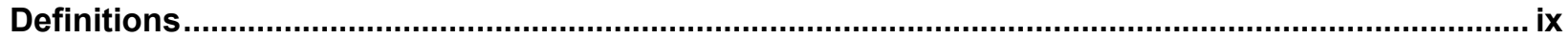

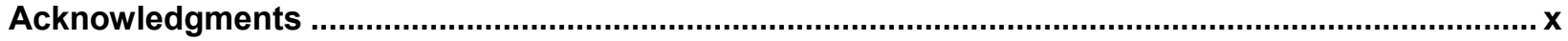

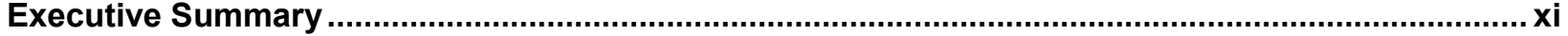

1 Introduction

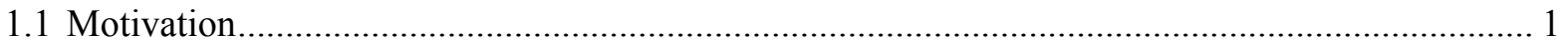

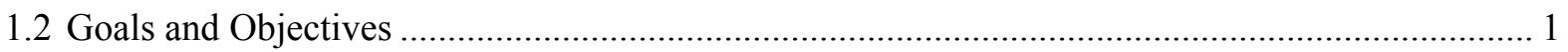

1.3 Background on High-Performance Distribution Systems ........................................................... 2

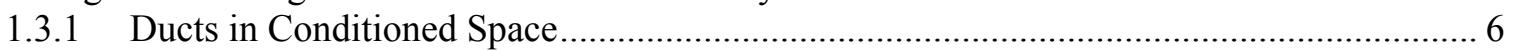

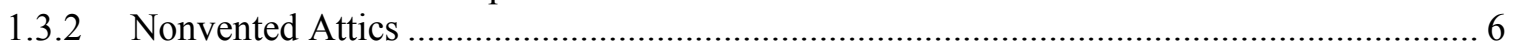

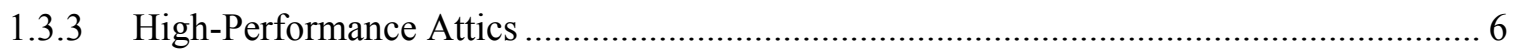

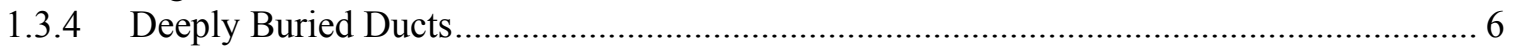

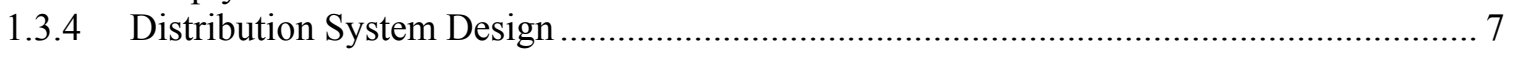

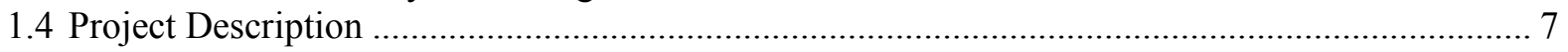

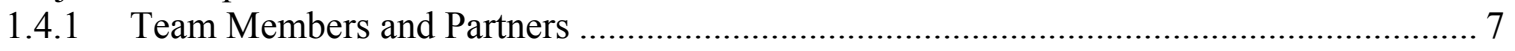

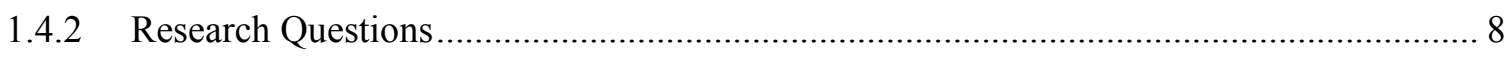

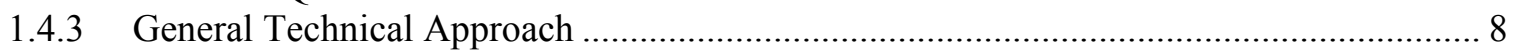

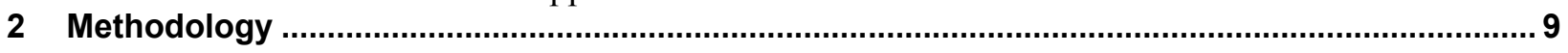

2.1 Builder Recruitment and House Selection ............................................................. 9

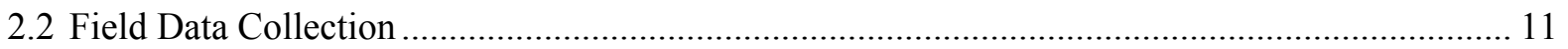

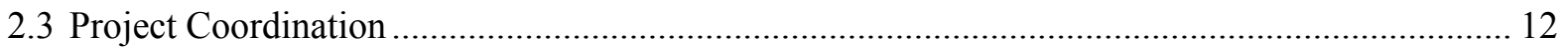

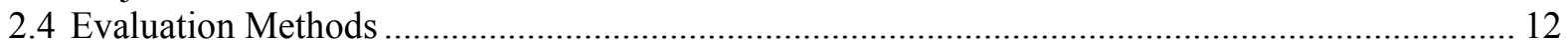

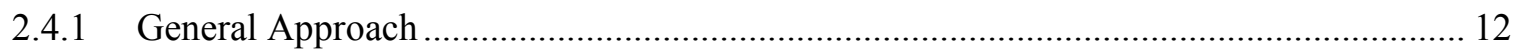

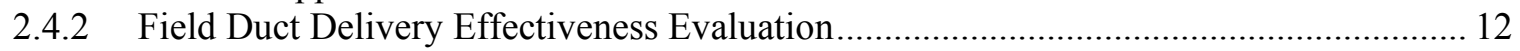

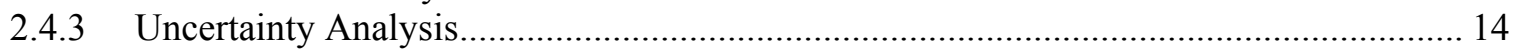

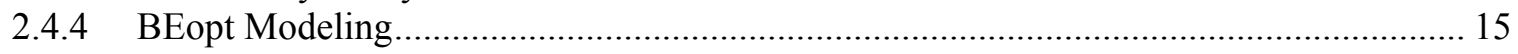

2.4.5 Costs for High-Performance Duct Strategies............................................................ 17

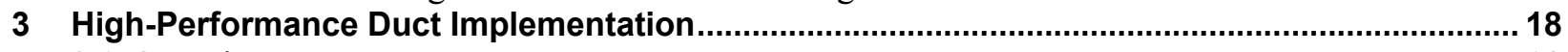

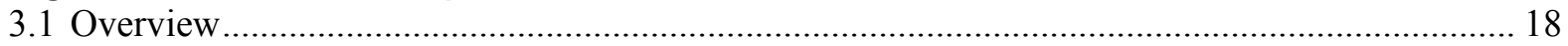

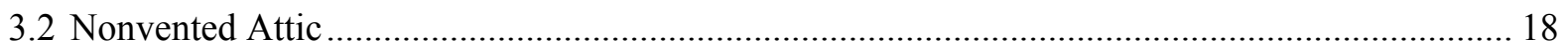

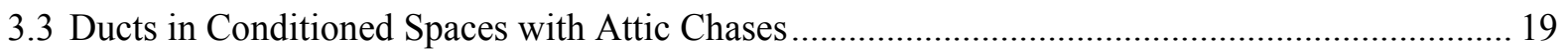

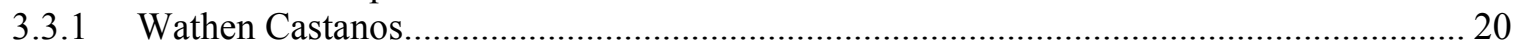

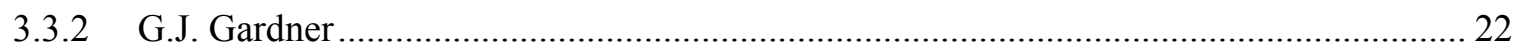

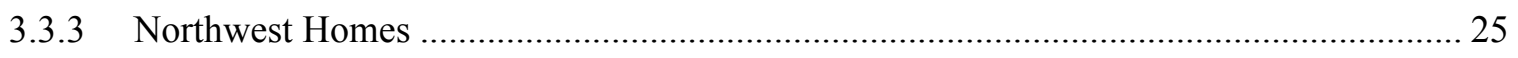

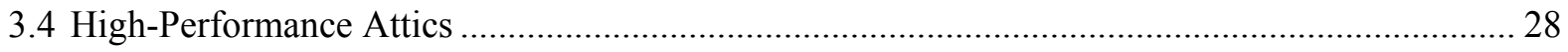

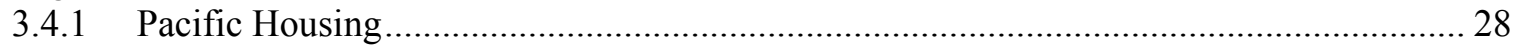

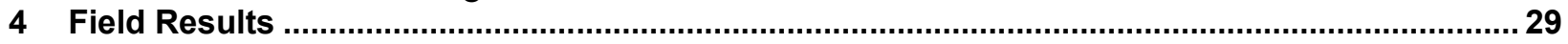

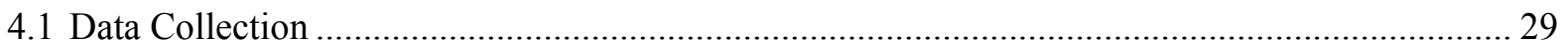

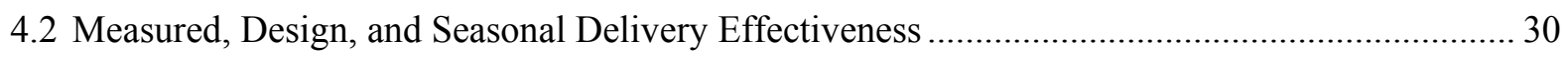

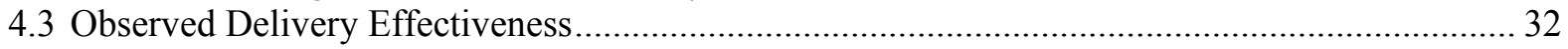

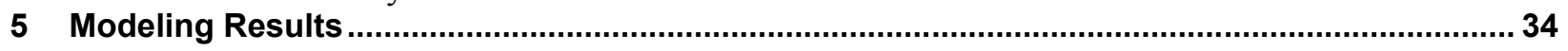

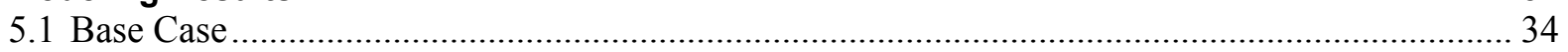

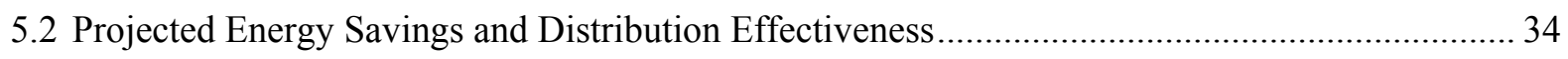

5.3 Additional Parametric Analysis Results ............................................................................... 39

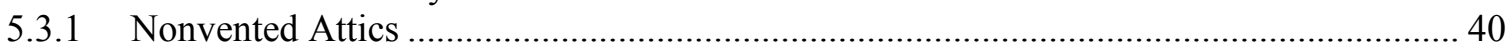

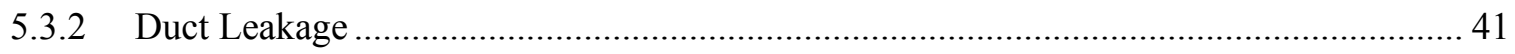

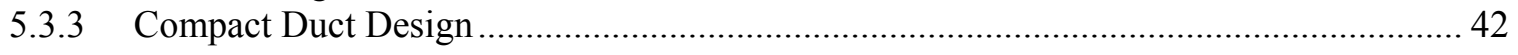


6 High-Performance Duct System Costs and Cost-Effectiveness ............................................ 43

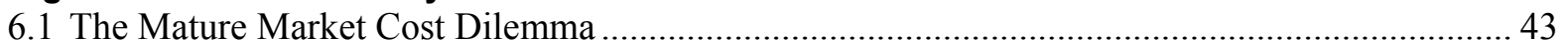

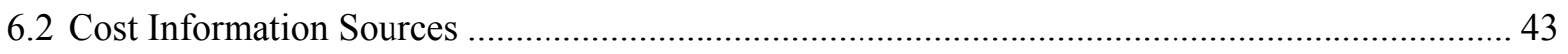

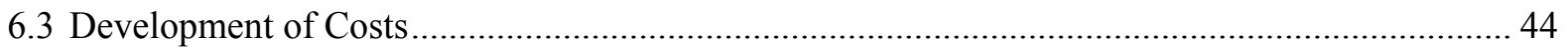

6.3.1 Measures Included ........................................................................... 44

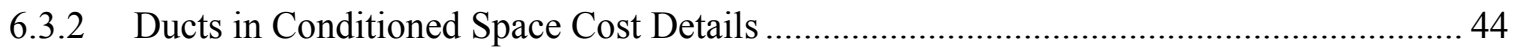

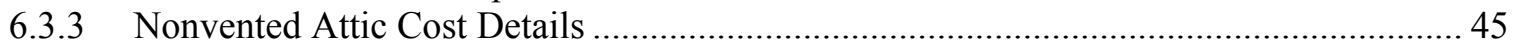

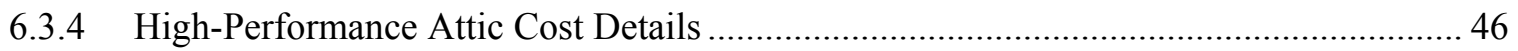

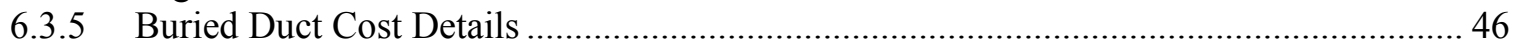

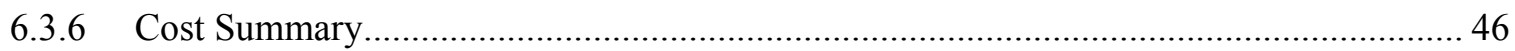

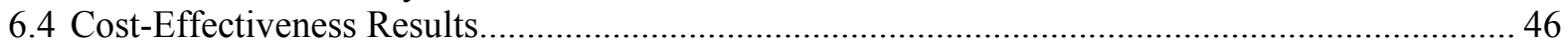

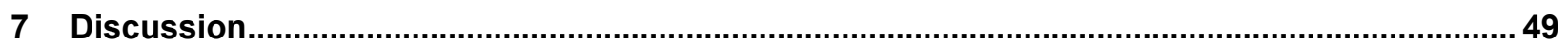

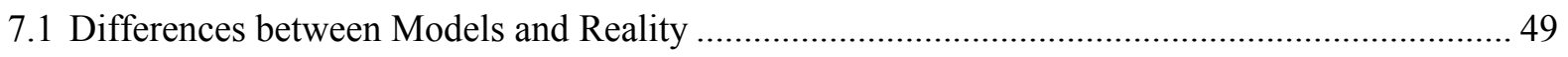

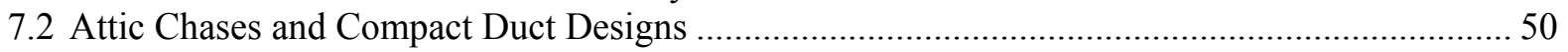

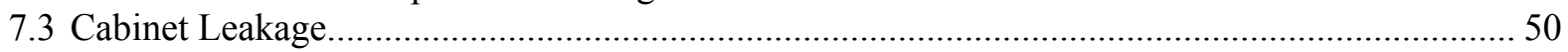

7.4 A Comprehensive Approach to HVAC Efficiency .............................................................. 51

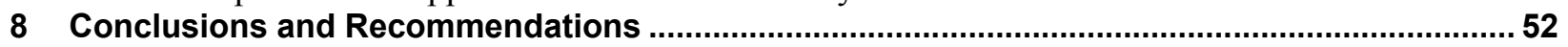

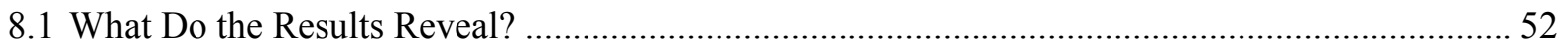

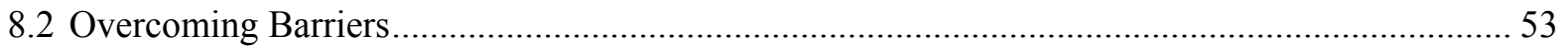

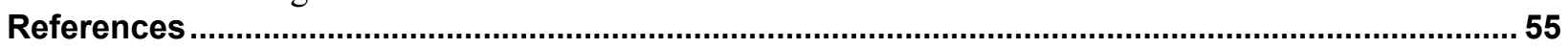

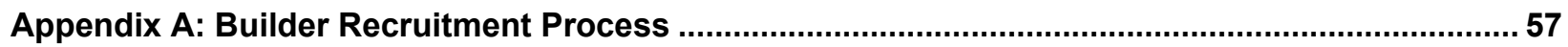

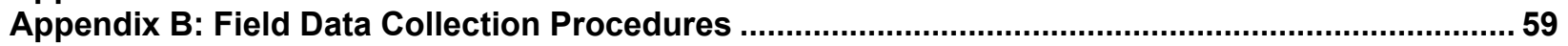

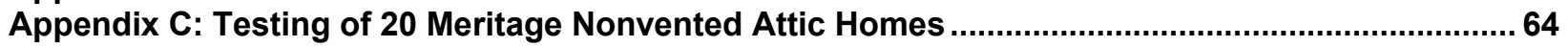

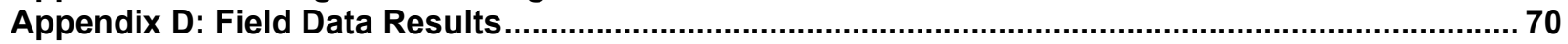

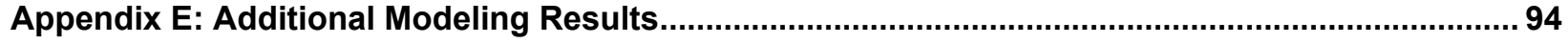




\section{List of Figures}

Figure 1. Schematic of business-as-usual and alternative HPD strategies .................................... 4

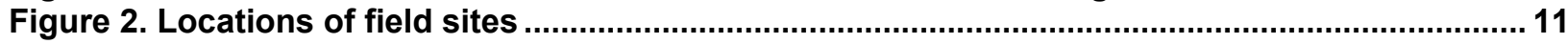

Figure 3. Meritage's NVA with spray-foamed roof deck ............................................................. 18

Figure 4. Drywall-lined duct chase in the Wathan Castanos house .............................................. 21

Figure 5. Attic mechanical closet viewed from inside (left) and outside (right) ...............................21

Figure 6. Wathen Castanos 1,870-ft ${ }^{2}$ plan attic mechanical closet (shaded) and duct chases ........ 22

Figure 7. Recommended compact duct design for G.J. Gardner 1,816-ft ${ }^{2}$ plan ................................ 23

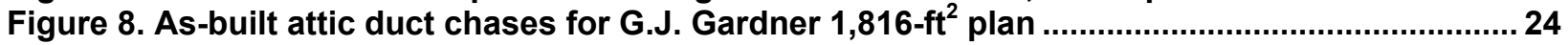

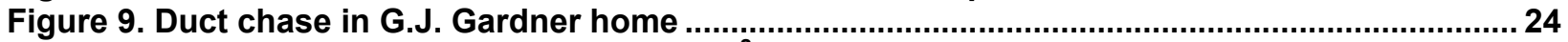

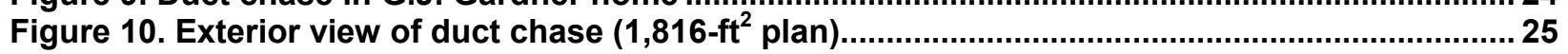

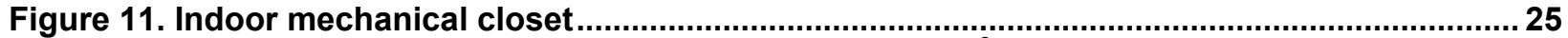

Figure 12. Attic duct chase plan for Northwest Homes 2,205- $\mathrm{ft}^{2}$ plan......................................... 26

Figure 13. Duct chase and boot for register (left); mechanical closet (right), Northwest Homes

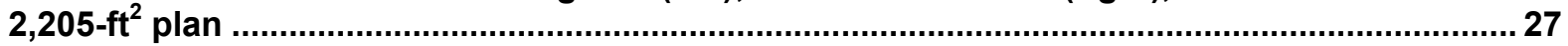

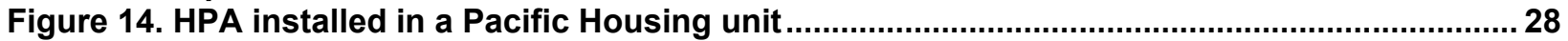

Figure 15. Comparison of heating and cooling ODEs versus Standard 152 single-point DEs......... 33

Figure 16. Phoenix annual HVAC source energy comparison $\left(2,100-\mathrm{ft}^{2}\right.$ prototype $) . . . . . . . . . . . . . . . . . . . .35$

Figure 17. Albuquerque annual HVAC source energy comparison $\left(2,100-\mathrm{ft}^{2}\right.$ prototype).....................36

Figure 18. Phoenix DSE comparison $\left(2,100-\mathrm{ft}^{2}\right.$ prototype) ............................................................... 36

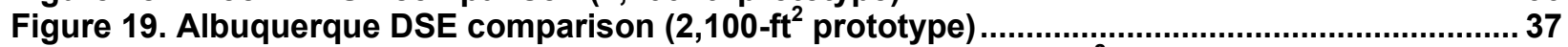

Figure 20. Phoenix annual HVAC source energy comparison $\left(2,700-\mathrm{ft}^{2}\right.$ prototype $) . . . \ldots \ldots \ldots \ldots \ldots \ldots . . . . . . . . .37$

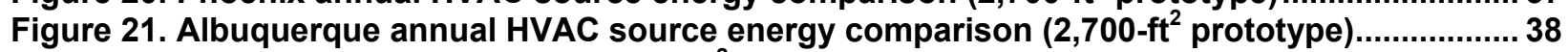

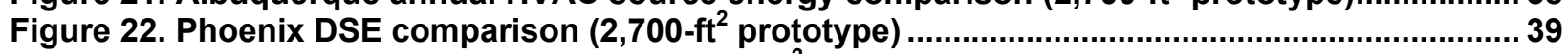

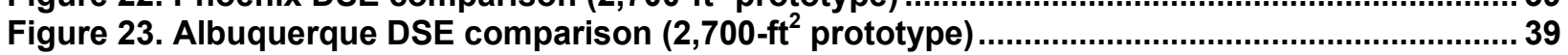

Figure 24. NVA comparison with various house infiltration values ............................................... 40

Figure 25. NVA comparison of hip versus gable roofs ............................................................. 41

Figure 26. Impact of reducing duct leakage from $15 \%$ to $6 \%$ for typical attic duct systems ............ 41

Figure 27. Source energy use comparison for typical duct designs (Benchmark assumptions) .... 42

Figure 28. Source energy use for compact duct designs .............................................................. 42

Figure 29. HPD projected cost-effectiveness range across modeled climates.................................. 48

Figure 30. Infrared image of attic duct chase during heating operation ........................................... 49

Figure 31. Annual HVAC source energy use comparison by climate for $2,100-\mathrm{ft}^{2}$ prototype ...........99

Figure 32. Distribution effectiveness comparison by climate for $2,100-\mathrm{ft}^{2}$ prototype ..................... 99

Figure 33. Annual HVAC source energy use comparison by climate for $2,700-\mathrm{ft}^{2}$ prototype ......... 100

Figure 34. Distribution effectiveness comparison by climate for $2,700-\mathrm{ft}^{2}$ prototype ..................... 100

Unless otherwise noted, all figures were created by the ARBI team 


\section{List of Tables}

Table 1. DE Results Summary xii

Table 2. Summary of BEopt Distribution Analysis Results .......................................................... xii

Table 3. Pros and Cons of Alternative HPD Implementation Strategies ........................................ 5

Table 4. Builders That Participated in the HPD Demonstration .................................................... 10

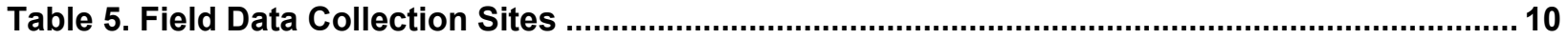

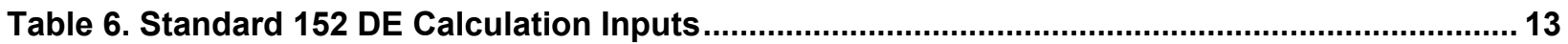

Table 7. Diagnostic Equipment Used in Field Testing ................................................................ 14

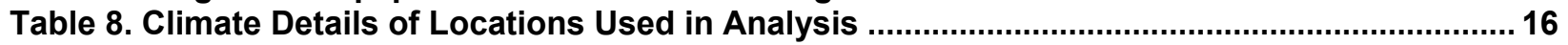

Table 9. Duct Surface Area and Duct Location for Base Case............................................................ 17

Table 10. Test Site Duct Surface Area Measurements ..................................................................... 29

Table 11. Key Site Collected Parameters for Standard 152 DE Determination................................... 30

Table 12. DE Results Calculated Using Standard 152 and Measured Temperatures ...................... 31

Table 13. DE Results Calculated Using Standard 152 and Design and Seasonal Temperatures..... 32

Table 14. Base-Case BEopt Modeling Results............................................................................ 34

Table 15. 2,100-ft ${ }^{2}$ One-Story Prototype Source Energy Savings Results ......................................... 35

Table 16. 2,700-ft ${ }^{2}$ two-story Prototype Source Energy Savings Results ........................................... 35

Table 17. Estimated Costs for Attic Chase and Drop Ceiling DCS Configurations .......................... 45

Table 18. Estimated Costs for NVA Strategy.............................................................................. 45

Table 19. Summary of Estimated Advanced Distribution System Costs ........................................... 46

Table 20. 2,100-ft ${ }^{2}$ One-Story Prototype Cost-Effectiveness ........................................................ 47

Table 21. 2,700-ft ${ }^{2}$ Two-Story Prototype Cost Effectiveness ............................................................ 47

Table 22. Comparison of Measured and Simulated DE................................................................... 50

Table 23. Specification of Optimized "Hot-Dry" HVAC Performance for ZERHs ............................51

Table 24. Builders Contacted Who Chose Not To Participate ............................................................. 58

Table 25. Whole-House and Attic Infiltration (with attic hatch closed) ........................................67

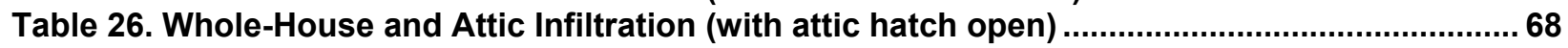

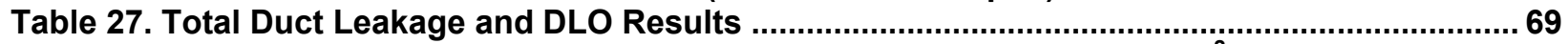

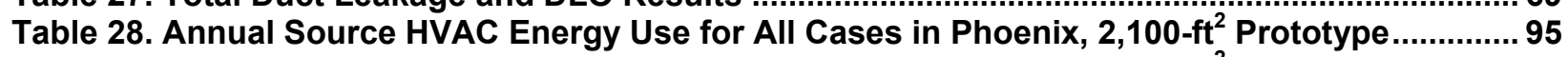

Table 29. Annual Source HVAC Energy Use for All Cases in Phoenix, 2,700- $\mathrm{ft}^{2}$ Prototype................. 95

Table 30. Annual Source HVAC Energy Use for All Cases in Fresno, 2,100- $\mathrm{ft}^{2}$ Prototype.................. 96

Table 31. Annual Source HVAC Energy Use for All Cases in Fresno, 2,700- $\mathrm{ft}^{2}$ Prototype .................96

Table 32. Annual Source HVAC Energy Use for All Cases in Sacramento, 2,100- $\mathrm{ft}^{2}$ Prototype ....... 97

Table 33. Annual Source HVAC Energy Use for All Cases in Sacramento, 2,700- $\mathrm{ft}^{2}$ Prototype ....... 97

Table 34. Annual Source HVAC Energy Use for All Cases in Albuquerque, 2,100- $\mathrm{ft}^{2}$ Prototype ..... 98

Table 35. Annual Source HVAC Energy Use for All Cases in Albuquerque, 2,700- $\mathrm{ft}^{2}$ Prototype ..... 98

Unless otherwise noted, all tables were created by the ARBI team. 


\section{Definitions}

\begin{tabular}{|c|c|}
\hline AHU & Air Handling Unit \\
\hline ARBI & Alliance for Residential Building Innovation \\
\hline ASHRAE & $\begin{array}{l}\text { American Society of Heating, Refrigerating and Air-Conditioning } \\
\text { Engineers }\end{array}$ \\
\hline BEopt ${ }^{\mathrm{TM}}$ & Building Energy Optimization software tool \\
\hline CAHP & California Advanced Home Program \\
\hline $\mathrm{CEC}$ & California Energy Commission \\
\hline $\operatorname{ccSPF}$ & Closed-Cell Spray Polyurethane Foam \\
\hline $\mathrm{DBD}$ & Deeply Buried Duct \\
\hline DCS & Duct in Conditioned Space \\
\hline $\mathrm{DE}$ & Delivery Effectiveness \\
\hline DSE & Distribution System Efficiency \\
\hline DEG & Davis Energy Group \\
\hline DLO & Duct Leakage to Outside \\
\hline DSA & Duct Surface Area \\
\hline HERS & Home Energy Rating System \\
\hline HPA & High-Performance Attic \\
\hline HPD & High-Performance Duct \\
\hline HVAC & Heating, Ventilation, and Air Conditioning \\
\hline NVA & Nonvented Attic \\
\hline ocSPF & Open-Cell Spray Polyurethane Foam \\
\hline ODE & Observed Delivery Effectiveness \\
\hline OSB & Oriented Strand Board \\
\hline PIER & Public Interest Energy Research \\
\hline PG\&E & Pacific Gas \& Electric Company \\
\hline ZERH & Zero Energy Ready Home \\
\hline
\end{tabular}




\section{Acknowledgments}

The Alliance for Residential Building Innovation team acknowledges the support of the Pacific Gas \& Electric Company in providing the foundation on which this work was based. With Pacific Gas \& Electric Emerging Technologies and Codes and Standards team support, the Alliance for Residential Building Innovation was able to assemble a strong team to conduct the necessary assessments and evaluations to complete this study. In particular, the authors would like to highlight the contributions of Rick Chitwood in leading the field activities under this project and his efforts in working with builders to influence design practices.

The authors would also like to acknowledge the builder partners who provided their valuable time and resources to participate in the project and provide access to jobsites and vital information about costs and construction issues related to implementing ducts in conditioned space in new California homes. 


\section{Executive Summary}

Duct thermal losses and air leakage have long been recognized as prime culprits in the degradation of heating, ventilating, and air-conditioning (HVAC) system efficiency. Both the U.S. Department of Energy's Zero Energy Ready Home program and California's proposed 2016 Title 24 Residential Energy Efficiency Standards require that ducts be installed within conditioned space or that other measures be taken to provide similar improvements in delivery effectiveness (DE).

Pacific Gas \& Electric Company commissioned a study to evaluate ducts in conditioned space and high-performance attics (HPAs) in support of the proposed codes and standards enhancements included in California's 2016 Title 24 Residential Energy Efficiency Standards. The goal was to work with a select group of builders to design and install high-performance duct (HPD) systems, such as ducts in conditioned space (DCS), in one or more of their homes and to obtain test data to verify the improvement in DE compared to standard practice. Davis Energy Group (DEG) helped select the builders and led a team that provided information about HPD strategies to them. DEG also observed the construction process, completed testing, and collected cost data.

The Alliance for Residential Building Innovation (ARBI) is one of the U.S. Department of Energy's Building America research teams. In this project ARBI recognized the opportunity to expand Building America's knowledge of HPD as it applies to dry climates. In addition to gathering field data that would be useful to the Building America program, DEG and the ARBI team completed simulations using Building Energy Optimization (BEopt ${ }^{\mathrm{TM}}$ ) to extrapolate the California results to other dry-climate locations, such as Arizona and New Mexico.

Five builders provided a total of seven homes in which to test high-performance distribution systems and nine to test base-case systems that have standard attic ducts. Design assistance included recommendations for rightsizing equipment and compact duct design using furred-up or dropped-ceiling duct chases. Three of the builders chose to construct duct chases through attic trusses; one of these built a sealed mechanical space to keep equipment above the ceiling plane. A fourth builder that was already experienced with nonvented attics (NVAs) provided two homes for testing. The fifth builder dedicated a recently constructed home to test the HPA strategy. This home was retrofitted with R-11 roof deck insulation, and R-6 ducts were replaced with R-8 ducts sealed to less than 5\% leakage.

On-site measurements and testing were completed to characterize DE for each house in four ways: (1) based on observed Btu delivered to the registers divided by total energy supplied to the duct system, (2) using American Society of Heating, Refrigerating and Air-Conditioning Engineers Standard 152 methods and observed temperature conditions and airflow, (3) using Standard 152 methods to derive "seasonal" DE, and (4) using Standard 152 methods to derive "design" DE. The range of DE values calculated used measured conditions, Standard 152 methods, and winter and summer temperature conditions (Table 1). "Standard vented attic" ducts were insulated to R-6 or R-8 and tightly sealed. 
Table 1. DE Results Summary

\begin{tabular}{c|c}
\hline Distribution System Type & DE \\
\hline Standard Vented Attic & $85.9 \%-89.7 \%$ \\
DCS & $95.1 \%-99.6 \%$ \\
Insulated NVA & $98.8 \%-99.1 \%$ \\
Vented HPA & $93.1 \%-93.4 \%$ \\
\hline
\end{tabular}

BEopt was used to model four distribution system types, the three that were evaluated in the field plus deeply buried ducts (DBDs). Modeling was completed for two houses in four climates. The climates represent the two places in California where houses were located (Fresno and Sacramento), a very hot-dry climate (Phoenix), and a mixed-dry climate (Albuquerque). Because BEopt calculates perfect (100\%) DE for DCS, the BEopt modeling results shown in Table 2 present savings for the other three distribution systems as a percentage relative to the DCS case. For example, in the one-story house in Phoenix, annual energy savings with an HPA (5.7 MBtu) represent $69 \%$ of the savings achieved with DCS (8.8 MBtu). The DBD case applied R-60 instead of R-30 insulation to the entire ceiling, which improved the thermal enclosure and caused it to perform better than DCS in the one-story house. (In practice, R-60 insulation would typically be applied to achieve DBDs.)

Table 2. Summary of BEopt Distribution Analysis Results

\begin{tabular}{|c|c|c|c|c|}
\hline \multirow{2}{*}{$\begin{array}{c}\text { Distribution System } \\
\text { Type }\end{array}$} & $\begin{array}{l}\text { Phoenix } \\
(\%)\end{array}$ & $\begin{array}{c}\text { Fresno } \\
(\%)\end{array}$ & $\begin{array}{c}\text { Sacramento } \\
(\%)\end{array}$ & $\begin{array}{c}\text { Albuquerque } \\
(\%)\end{array}$ \\
\hline & \multicolumn{4}{|c|}{ One-Story, 2,100 $\mathrm{ft}^{2}$} \\
\hline HPA & 65 & 62 & 54 & 28 \\
\hline DBD & 89 & 114 & 128 & 102 \\
\hline \multirow{2}{*}{ NVA } & 49 & 46 & 65 & 54 \\
\hline & \multicolumn{4}{|c|}{ Two-Story, 2,700 $\mathrm{ft}^{2}$} \\
\hline HPA & 61 & 57 & 50 & 31 \\
\hline DBD & 72 & 89 & 99 & 83 \\
\hline NVA & 73 & 74 & 86 & 77 \\
\hline
\end{tabular}

A cost-effectiveness analysis that was completed using costs from builders and other sources and annual energy savings from simulations showed that:

- DCS using dropped ceilings was the most cost-effective approach (the model assumes a DE of $100 \%$ ). Constructing attic chases was less cost-effective because of the high cost of constructing, air sealing, and insulating the chases. The model did not account for the increase in the area of the thermal enclosure caused by attic chases or imperfect sealing of the chases, which would further favor the dropped-ceiling approach.

- Modeling showed DBDs (with R-60 ceiling insulation) to be the second most costeffective measure in one- and two-story houses. To perform as modeled, ducts must be fully buried and tightly sealed, and furnaces must be installed in conditioned space or have low leakage. 
- The HPA strategy of insulating a vented attic in the ceiling and roof deck also competed well with other measures, but energy savings also depend on well-sealed ducts and lowleakage furnaces.

- The high cost of foaming the underside of the roof deck (to R-30) and increased surface area of the thermal enclosure caused the NVA measure to have the lowest costeffectiveness, especially for the one-story house. However, if the significant fielddocumented whole-house envelope leakage benefits are accounted for, the NVA performance improves close to the DCS case, albeit at a higher incremental cost.

Several barriers to the implementation of high-performance distribution systems were identified:

- Builder resistance to dropped ceilings based on the perception that they will decrease market value

- HVAC contractor resistance to right-sizing and compact duct designs that can reduce the size of ducts and space required for interior duct chases

- Lack of coordination between builders, architects, and HVAC and other subcontractors

- Scarcity of good examples and case studies of HPD systems. 


\section{Introduction}

\subsection{Motivation}

A project sponsored by Pacific Gas \& Electric Company (PG\&E) to improve the efficiency of heating, ventilating, and air-conditioning (HVAC) distribution systems provided the opportunity to research alternatives to inefficient attic-installed ducting and equipment. The purpose of the project was to develop information that would support changes to California Title 24 standards, but the value of the information extends to all hot-dry and mixed-dry climates.

Enacted in 1974, the Warren-Alquist Act created the California Energy Commission (CEC) and enabled the state to create and periodically update energy standards. These standards, which fall under Title 24, Part 6 of the California Code of Regulations, have saved Californians more than $\$ 74$ billion in electricity bills since 1977 and constitute a significant factor in California's percapita electricity use remaining flat during the last 40 years while the rest of the country's use has continued to rise. The Title 24 building energy standards are updated about once every 3 years and are on a trajectory to achieve zero energy ${ }^{1}$ by 2020 . The CEC develops codes and standards enhancement reports that propose and evaluate particular measures for adoption. The reports must demonstrate that measures are cost-effective, and draft standards that are prepared from them are vetted through public workshops.

One measure chosen by the Statewide Investor Owned Utilities Codes and Standards Team for inclusion in the 2016 standards rulemaking is ducts in conditioned space (DCS). PG\&E, as a core member of this team, selected Davis Energy Group (DEG) to conduct research to support the development of a codes and standards enhancement report about this topic (CEC 2015). The U.S. Department of Energy's Building America research team Alliance for Residential Building Innovation (ARBI) saw the opportunity to leverage this work to help transform the market in California and other hot-dry climates in advance of the 2016 standards process and to develop information that potential U.S. Department of Energy Zero Energy Ready Home (ZERH) builders and other progressive builders could apply. Consequently, the project approach and methodology were guided by the dual objectives of developing information to support California codes and standards and addressing Building America research priorities.

\subsection{Goals and Objectives}

Improving delivery effectiveness (DE) by moving ducts into conditioned space or other means is a critical step in reducing HVAC energy consumption, especially in hot-dry and mixed-dry climates where ducts are nearly always installed in unconditioned attics rather than in basements or crawlspaces. The project described in this report responds directly to NREL's internal critical path planning document, ${ }^{2}$ which includes the following goal:

"SC3: In 2015, document new construction community scale adoption of space conditioning distribution system solutions that ensure negligible conductive, radiant, and leakage losses in new and existing low-load homes."

The project was structured to address the conditions that builders face with respect to placing ducts and equipment inside conditioned space, including increased cost, difficulty of

\footnotetext{
${ }^{1}$ Using California's Time Dependent Valuation methodology

${ }^{2} 2013$ Building America Technical Innovations Leading to 50\% Savings-A Critical Path
} 
implementation, risk, homeowner comfort expectations, market factors, and the level of training HVAC contractors need to successfully execute alternative distribution system designs.

The goal of this project was to identify the most cost-effective methods for improving DE in hotdry and mixed-dry climate homes where ducts and equipment are typically installed in attics. Project objectives were to engage multiple builders in California and to help them implement high-performance ducts (HPDs) in one or more test homes, document their experiences and their ability to deliver these systems, use field measurements to verify performance, and complete detailed modeling to assess impacts and cost-effectiveness in various hot-dry climates. Findings from this work were used to help support the development of a Title 24 building energy code change proposal for the 2016 Title 24 revisions that were adopted June 2015.

\subsection{Background on High-Performance Distribution Systems}

The development of ASHRAE Standard 152 in the late 1990s culminated many years of detailed research on the performance of residential HVAC delivery systems (ASHRAE 2004). Standard 152 quantifies the energy implications of delivering air from HVAC equipment through ducts as a function of duct location, size (length and diameter), insulation levels, climate, and HVAC equipment type and capacity. In developing this standard, the building energy research community and the construction industry gained a much better understanding of the impacts and potential energy and demand savings of improved duct system performance. The standard was incorporated into California's energy compliance methods in 2005.

Building America teams have been researching methods for improving distribution system performance by burying ducts in ceiling insulation, moving them into conditioned space, or eliminating vented attics (Burdick 2013b; Shapiro et al. 2013). Ongoing research has identified various strategies to place ducts within the thermal envelope (Lubliner et al. 2008; Hales and Baylon 2010; Beal et al. 2011) ${ }^{3}$ and approaches to improve duct performance in unconditioned attic spaces (Shapiro et al. 2013). Despite the compelling evidence that DCS can substantially improve heating and cooling system performance and facilitate equipment downsizing, building industry inertia has prevailed, and builders and building designers are generally averse to making the architectural, structural, and mechanical changes that are necessary to take this step.

In regions where basements are common, integrating DCS is often easier than in regions where slab-on-grade construction dominates and ducts and HVAC equipment are primarily in unconditioned attics. Installing the air handling unit (AHU) and ducts so they are inside conditioned space is often challenging. Two of the key builder arguments against this strategy are (1) the need to give up valuable interior space for a mechanical closet, and (2) the cost, structural, and architectural impacts of creating chases for ducts that are within the thermal enclosure.

Significant reductions in duct leakage have been achieved during the past 20 years. In striving for U.S. Department of Energy ZERH performance levels, reducing or eliminating distribution loss is a critical factor, and additional performance improvements are needed. Hydronic delivery, nonducted systems such as mini-splits, and DCS all provide alternative approaches to further improve DE. Most new home HVAC installations continue to be built with ducted, forced-air systems; thus, identifying and implementing cost-effective, builder-friendly, HPD systems is

\footnotetext{
${ }^{3}$ See http://www.ductsinside.org/.
} 
critical to achieving the ZERH goal. Several implementation options are available, and some are suitable only for particular homes that are built above basements or on raised foundations. U.S. Department of Energy ZERH program materials ${ }^{4}$ and Northwest Energy Efficiency Alliance Ducts Inside (Earth Advantage Institute 2011) provide a comprehensive overview of implementation strategies, pros and cons, and roles and responsibilities for key participants, including architects, HVAC contractors, framers, and drywall installers.

Besides locating ducts within the thermal enclosure, some alternative strategies improve performance. For example, ducts can be buried in attic insulation and/or encapsulated in foam, ${ }^{5}$ and HPAs can be created. This latter concept is being explored in the warmer California climates and involves adding insulation above or below the roof deck and at the ceiling, increasing duct insulation levels, and reducing duct leakage to below current required levels.

This study evaluates the following five alternative HPD strategies as schematically represented in Figure 1:

- DCS: Equipment and ducts installed within the thermal enclosure

○ Drop ceiling - Ducts installed in a dropped-ceiling space below the ceiling plane

- Attic chase-Ducts installed in chases above the ceiling plane

- Nonvented attic (NVA): Ducts and equipment installed in an NVA that is insulated and sealed to outdoors

- HPA: Ducts and equipment in a vented attic with insulation at both the ceiling and above or below the roof sheathing

- Deeply buried ducts (DBDs): Ducts and equipment in a vented attic with ducts buried in additional ceiling insulation.

This project did not evaluate nonducted systems or hydronic distribution, which have been covered in other Building America reports (Springer et al. 2012; Ueno and Loomis 2014). More details about the five HPD strategies are provided below; pros and cons are listed in Table 3.

\footnotetext{
${ }^{4}$ See http://energy.gov/eere/buildings/downloads/doe-zero-energy-ready-home-webinar-ducts-conditioned-space.

${ }^{5}$ Encapsulated ducts typically use 1-2 in. of closed-cell spray foam on ducts that are placed on the attic floor. Encapsulating with a vapor barrier is needed to avoid moisture condensation on the duct surface in more humid climates before the ducts are buried in attic insulation.
} 


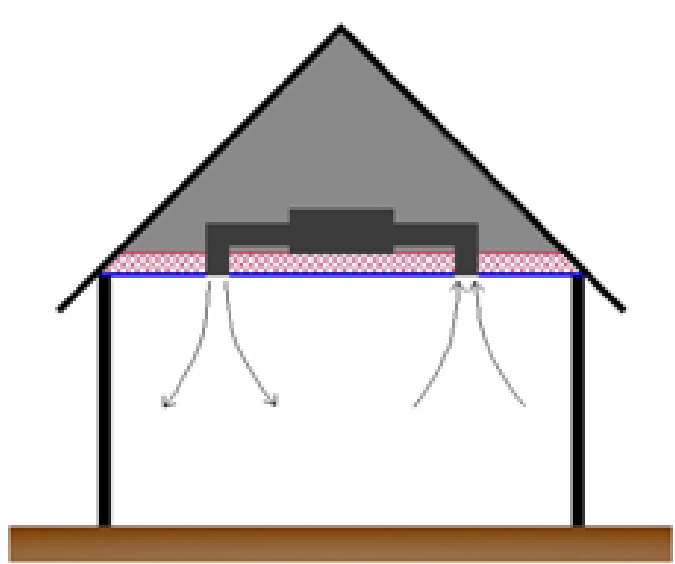

Typical Vented Attic

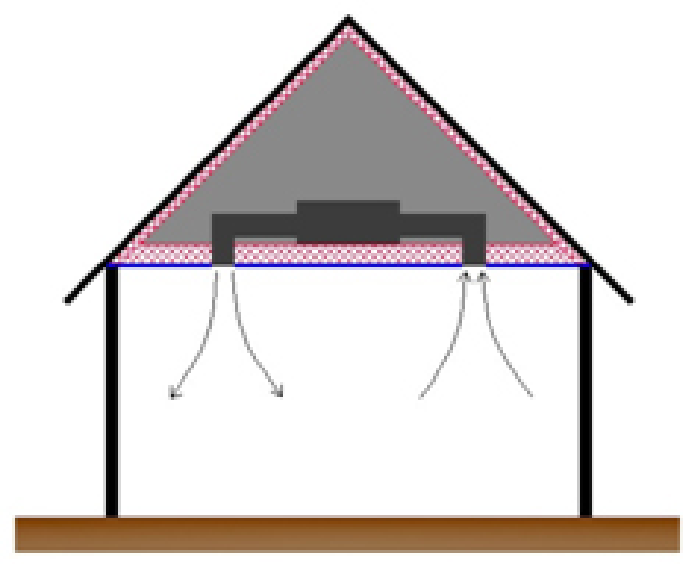

Vented High Performance Attic

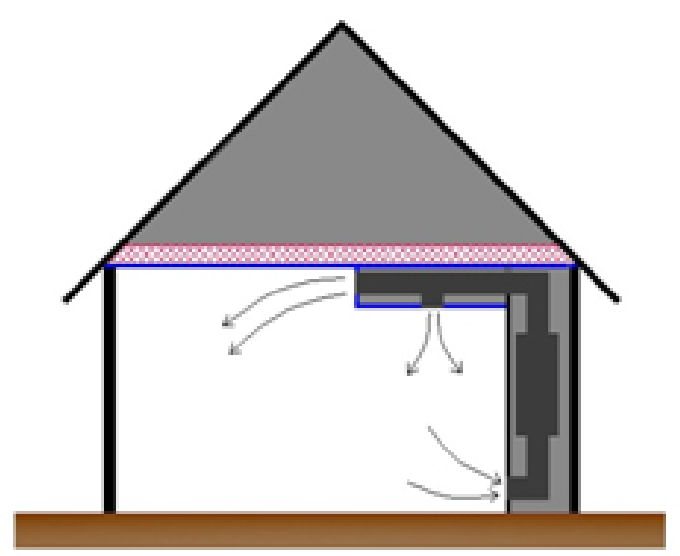

DCS with Dropped Ceiling

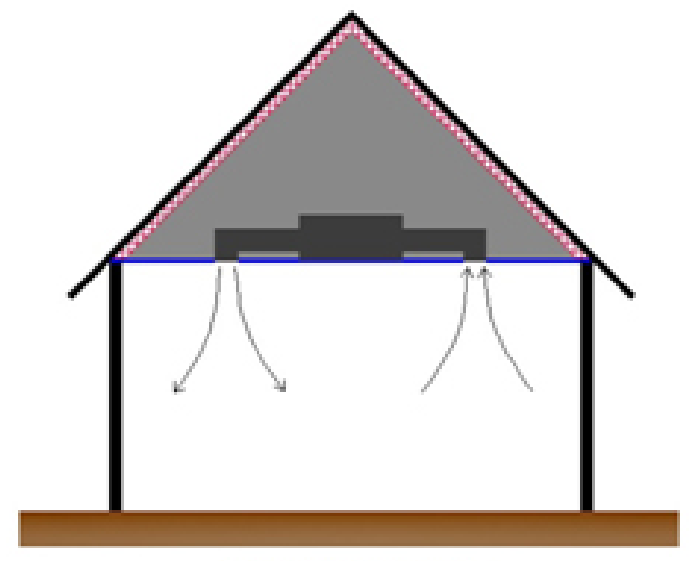

Unvented Attic

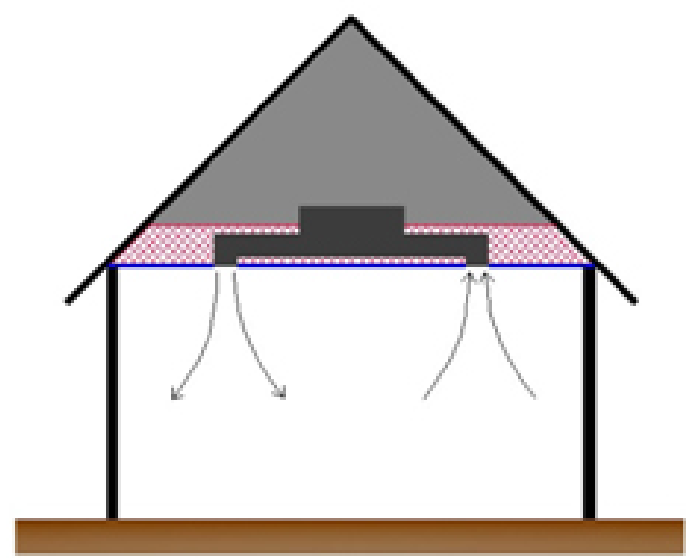

Buried Ducts in Vented Attic

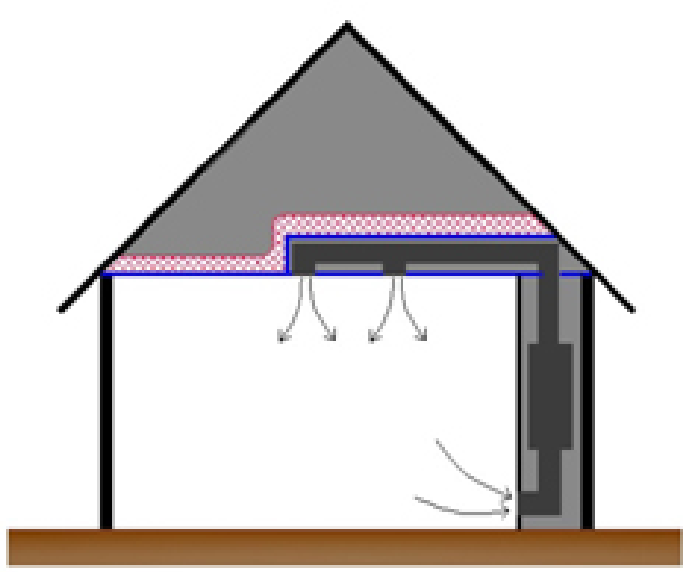

DCS with Attic Chase

Figure 1. Schematic of business-as-usual and alternative HPD strategies 
Table 3. Pros and Cons of Alternative HPD Implementation Strategies

\begin{tabular}{|c|c|c|}
\hline HPD Strategy & Pros & Cons \\
\hline $\begin{array}{l}\text { DCS Dropped } \\
\text { Ceiling }\end{array}$ & $\begin{array}{l}\text { - Fairly low cost in simple plans } \\
\text { - Generally leads to compact duct designs }\end{array}$ & $\begin{array}{l}\text { - May be challenging to implement in some plans } \\
\text { - Challenges the HVAC industry on proper duct design, room-by- } \\
\text { room airflow, and register throw } \\
\text { - Requires additional air-sealing step and construction coordination } \\
\text { - Requires AHU/furnace in conditioned space (sealed combustion } \\
\text { furnace) } \\
\text { - Builders are concerned about ceiling drops and an interior } \\
\text { mechanical closet }\end{array}$ \\
\hline $\begin{array}{l}\text { DCS } \\
\text { Attic Chases }\end{array}$ & $\begin{array}{l}\text { - Conceptually easy to implement } \\
\text { - Does not impact ceiling heights } \\
\text { - Less constrained by the house plan than the } \\
\text { dropped-ceiling approach }\end{array}$ & $\begin{array}{l}\text { - Adds complexity and cost because proper air sealing of chases and } \\
\text { insulating of chase sidewalls are required } \\
\text { - Chases can interfere with attic access and ability to properly install } \\
\text { attic insulation } \\
\text { - AHU/furnace in conditioned space (sealed combustion furnace) }\end{array}$ \\
\hline NVA & $\begin{array}{l}\text { - Implementation is not very sensitive to plan } \\
\text { configuration } \\
\text { - Provides for easy future HVAC service access } \\
\text { and general attic access } \\
\text { - Does not impact HVAC design and other trades } \\
\text { - Eliminates some costs (attic venting, attic air } \\
\text { sealing) } \\
\text { - Does not require indoor space for AHU/furnace }\end{array}$ & $\begin{array}{l}\text { - Increases conditioned envelope area and resulting heat flow so } \\
\text { quality installation is critical } \\
\text { - Requires skilled spray foam installer to achieve quality sealing and } \\
\text { insulation } \\
\text { - Sealed combustion furnaces are required } \\
\text { - Fairly costly for spray foam application }\end{array}$ \\
\hline HPA & $\begin{array}{l}\text { - Straightforward for builders to implement with } \\
\text { no significant change from standard practices } \\
\text { - Does not impact HVAC design and other trades } \\
\text { - Applicability not sensitive to plan configuration }\end{array}$ & $\begin{array}{l}\text { - Performance benefits need to be documented in the field } \\
\text { - AHU/furnace remains in unconditioned space }\end{array}$ \\
\hline DBD & $\begin{array}{l}\text { - In hot-dry climates, no need for duct } \\
\text { encapsulation } \\
\text { - Does not impact HVAC design and other trades } \\
\text { - Applicability not sensitive to plan } \\
\text { configuration; easy to implement }\end{array}$ & $\begin{array}{l}\text { - AHU/furnace may remain in unconditioned space (alternatively it } \\
\text { can be installed in interior mechanical closet) } \\
\text { - Requires raised heel truss and/or elimination of soffit venting } \\
\text { - Encapsulation of ducts, which is necessary in more humid climates, } \\
\text { adds cost }\end{array}$ \\
\hline
\end{tabular}




\subsubsection{Ducts in Conditioned Space}

The two basic methods for creating duct chases inside the thermal enclosure are (1) dropping or furring down ceilings after the ceiling is drywalled, and (2) creating "attic chases" above the ceiling plane. Attic chases may be framed and sheathed with standard trusses or may use custom trusses that have recesses to accommodate the chases. Attic chases must be thoroughly sealed and insulated. Beal et al. (2011) and others describe these methods.

\subsubsection{Nonvented Attics}

NVAs are an alternative to DCS in which insulation is installed at the roof deck instead of at the attic floor and the attic is sealed, moving the pressure-thermal boundary from the ceiling to the roof deck. Over the years several major national builders - including Meritage, Shea, and Pulte Homes - have used this approach. Although insulating at the roof deck increases the insulated envelope surface area and resulting heat transfer, it easily accommodates ducts and HVAC equipment within conditioned space and provides some cost savings by eliminating attic venting and reducing the labor required for air sealing at the ceiling plane. Insulation installation options include open-cell spray polyurethane foam (ocSPF) or closed-cell polyurethane spray foam (ccSPF) at the roof deck or application of blown insulation using a netting system as described in a recent CEC blueprint. ${ }^{6}$ Although roof deck moisture issues may cause some concerns, Grin et al. (2013) used a combination of detailed hygrothermal modeling and field inspections and indicated that using spray foam insulation under plywood and oriented strand board (OSB) roof decks presents no known risks if the following requirements are met:

- The installation complies with the 2012 International Residential Code.

- A fully adhered leak-free roof membrane is installed.

- The roof sheathing and framing are dry and have a moisture content lower than $18 \%$ before the spray foam is applied.

- When using ocSPF, a low-perm Class II vapor retarder is installed when required (cold climates).

\subsubsection{High-Performance Attics}

The HPA concept, which was proposed by the CEC as a prescriptive measure for inclusion in the 2016 Title 24 Standards (CEC 2015), involves adding insulation to the roof deck, increasing duct insulation levels, and reducing duct leakage levels from a current $6 \%$ maximum level to $5 \%$. The primary benefit of the HPA approach is that it significantly reduces summer heating through the roof deck of the vented attic space below. It is most appropriate in climates where cooling loads are significant and heating loads are moderate.

\subsubsection{Deeply Buried Ducts}

Burying ducts partially or completely in loose fill attic insulation decreases their heat gain and loss. Shapiro et al. (2013) conducted detailed evaluations of this approach. In humid climates the ducts must be encapsulated with ccSPF insulation to prevent condensation on the duct surface. Encapsulation is not needed in hot-dry climates that have no condensation potential. Simulations by the Consortium for Advanced Residential Buildings predicted annual energy savings of 5\%$20 \%$ relative to typical ducts in vented attics.

\footnotetext{
${ }^{6}$ See December 2014 Blueprint at http://www.energy.ca.gov/efficiency/blueprint/.
} 


\subsubsection{Distribution System Design}

Good design practice and careful attention to Air Conditioning Contractors of America design principles are also important components of efficient, cost-effective distribution systems. Burdick (2013a, 2013b) outlines design steps and decision processes. Compact duct design is critical for minimizing implementation costs for HPD systems, especially those that use attic chases or furred ceilings to accommodate ducts.

As loads are reduced in low-load homes, the ability to achieve proper air velocities and throws becomes much more critical to achieving uniform comfort, especially in larger rooms. Historically, windows performed poorly and walls had lower levels of insulation, so supply outlets were placed at the perimeter of a room to deliver heating and cooling to the high-load thermal enclosure elements. With enhanced thermal enclosures this is no longer necessary; such homes are good applications for compact duct air distribution systems, particularly in typically benign climates that are common in much of the hot-dry region.

Characteristics of compact duct systems include smaller equipment, shorter ducts, fewer outlets, and lower material and installation costs. Compact duct systems are easier to fit into the structure and minimize losses to further reduce the load on the HVAC system. Challenges arise when contractors apply rules of thumb for sizing equipment and ducts and for selecting the types and locations of air outlets. These outdated practices can cause equipment to short cycle, inadequate latent cooling, and poor mixing of indoor air, all of which result in comfort problems. Compact distribution strategies should be considered early in the design stage. The Air Conditioning Contractors of America Manuals J, D, S, and T (Rutkowski 2009a-c, 2011) and Air Conditioning Contractors of America Standard 5 provide fundamental guidance for achieving quality HVAC design.

Siegel et al. (2002) compared duct DE that was calculated using the ASHRAE 152 Standard and empirical measurements from seven houses located in California, Texas, and Nevada. Field data collection involved careful measurement of duct physical parameters (length, diameter, R-value), and duct location, combined with diagnostic testing to complete the calculation of DE using the Standard 152 methodology. DE was empirically calculated by measuring airflow and inlet and exit temperatures and relative humidity for each supply duct. The results showed that the difference between measured DE and that calculated using Standard 152 was about 5 percentage points if weather data, duct leakage, and AHU flow are well known. However, the accuracy of the standard is strongly dependent on having good measurements of duct leakage and system airflow. The authors noted that "given [that] the uncertainty in the measured DE is typically also about 5 percentage points, the Standard 152P results are acceptably close to the measured data." A propagation of error analysis on the terms in the DE calculation, based on the uncertainty of input measurements, suggests errors in the measured DE of $3 \%-7 \%$.

\subsection{Project Description}

\subsubsection{Team Members and Partners}

Managed by ARBI team lead DEG, the project benefitted from the participation of several highly qualified participants:

- Stuart Tartaglia and Marshall Hunt of PG\&E provided project management and technical oversight. 
- $\quad$ Rick Chitwood of Chitwood Energy Management undertook various roles as a leading performance contractor, building scientist, trainer, and consultant to the California Energy Commission. Chitwood developed and presented conceptual HVAC design strategies to builders and their design team, completed field observations to document HPD implementation, completed diagnostic testing to assess HPD and base case duct system performance, and consulted with builder field staff.

- Jon McHugh of McHugh Energy is a consultant to PG\&E on its Title 24 codes and standards activities and participated in project planning.

- Ken Nittler of Enercomp provided high-level Title 24 modeling support.

- Allen Amaro, a Home Energy Rating Systems (HERS) rater, provided support for field data collection activities.

\subsubsection{Research Questions}

This project addresses the following research questions:

1. What major issues prevent production builders from adopting HPD systems?

2. What energy savings result from implementing these strategies in the houses evaluated, and how reliable are the estimates?

3. Which implementation methods are most cost-effective and builder-acceptable in western hot-dry climates?

4. What risk factors and implementation issues were identified in the field?

\subsubsection{General Technical Approach}

The following general technical approach was developed to respond to the research questions:

- Identify builders and projects (one or two sites per builder) that would serve as candidates for evaluation and secure participation agreements.

- Provide guidance and design support to builders and HVAC contractors on HPD options that are appropriate for the selected house plans.

- Work with builder teams to arrive at final design strategies.

- Complete duct system takeoffs and duct diagnostic testing for the advanced test homes and a set of "base-case" homes with conventional attic duct systems.

- Gather photographic and narrative information to document HVAC and HPD implementation practices at the various field sites.

- Use the Standard 152 methods to assess HPD performance.

- Use the Building Energy Optimization (BEopt $\left.{ }^{\mathrm{TM}}\right)$ simulation tool and information gathered in the field to assess HPD performance.

- Use estimated costs for various HPD strategies to calculate cost per source kBtu saved.

- When the HPD implementation stage is complete, gather cost data and builder feedback about construction issues, risk factors, and other installation-related matters. 


\section{Methodology}

\subsection{Builder Recruitment and House Selection}

To encourage participation in this emerging technologies project, PG\&E offered incentives to the participating builders that were willing to build homes with DCS. The builders were required to:

- Identify houses that would be built within the project timeline.

- Provide site access during construction.

- Share construction cost data.

- Conduct a final debriefing phone call.

Various avenues were explored to connect with builder candidates that operated within the PG\&E service territory. DEG coordinated with PG\&E to present a webinar on July 15,2013 , to introduce California HERS raters and builders that participated in the California Advanced Home Program (CAHP) to the utility's emerging technology program opportunity. DEG also announced the opportunity to its Building America builder partners, Leadership in Energy \& Environmental Design for Homes contacts, the California Association of Building Energy Consultants, and builders who attended the PCBC and California Building Industry Association meetings.

The opportunity was presented to 19 builders (listed in Appendix A). PG\&E offered builders consulting support and financial incentives. A short information piece that documented the benefits of HPD strategies and quantified the potential Title 24 benefits was provided to further encourage participation. Only one of the participating builders (Meritage Homes) had ever implemented DCS in a production home environment.

Five builders decided to fully participate; others agreed to permit site inspections and testing that would contribute to data about current practices and base-case duct performance. Reasons given for not participating included insufficient staff to manage the design and construction of "oneoff" houses, lack of interest in sharing cost information, and difficulty completing a house within the project schedule.

Table 4 lists the houses and builders that were included in the HPD study and provides details about the types of HPD approaches used. Meritage has built almost 10,000 homes with NVAs nationally over the past 4 years. The Pacific Housing site is an infill project in Sacramento at which the builder was willing to add insulation to the underside of the roof deck of a model home to test the HPA concept.

Table 5 lists the sites selected for base-case testing (denoted by "B-" in the ID notation) and the advanced HPD test sites (denoted by "A-" and the Builder number in the ID). Figure 2 shows the general geographic location of the field sites; the Anderson site is located farthest north (near Redding), Sanger is near Fresno to the south, and all other sites are within approximately a 1-hour drive of Sacramento. 
Table 4. Builders That Participated in the HPD Demonstration

\begin{tabular}{c|c|c}
\hline Builder & Location & HPD Implementation \\
\hline Wathen Castanos & Fresno & $\begin{array}{r}\text { Constructed attic duct chases to accommodate ducts and } \\
\text { built an attic mechanical closet to house the furnace. } \\
\text { Constructed attic duct chases to accommodate ducts and } \\
\text { provided an indoor mechanical closet. }\end{array}$ \\
Northwest Homes & $\begin{array}{c}\text { Redding } \\
\text { El Dorado } \\
\text { Hills }\end{array}$ & $\begin{array}{r}\text { Constructed attic duct chases to accommodate ducts and } \\
\text { provided an indoor mechanical closet. }\end{array}$ \\
Pacific Housing & Sacramento & $\begin{array}{r}\text { Sealed } \\
\text { conditioned attic with R-20 open cell spray foam } \\
\text { at the roof deck underside }\end{array}$ \\
\hline
\end{tabular}

Table 5. Field Data Collection Sites

\begin{tabular}{|c|c|c|c|c|c|c|c|}
\hline Site ID & Builder & Location & Lot \# & $\begin{array}{c}\text { Floor } \\
\text { Area }\end{array}$ & $\begin{array}{c}\text { \# of } \\
\text { Stories }\end{array}$ & $\begin{array}{c}\text { Duct } \\
\text { R-Value }\end{array}$ & Season Tested \\
\hline \multicolumn{8}{|c|}{ Base-Case Test Sites } \\
\hline B-1 & A & Vacaville & 508 & 2605 & 2 & 6 & $\begin{array}{l}\text { Duct surface area } \\
\text { test only }\end{array}$ \\
\hline B-2 & A & Vacaville & 447 & 2368 & 2 & 6 & Summer \\
\hline B-3 & B & Folsom & 65 & 1777 & 1 & 6 & $\begin{array}{l}\text { Duct surface area } \\
\text { (DSA) test only }\end{array}$ \\
\hline B-4 & $\mathrm{C}$ & Fresno & 40 & 1622 & 1 & 8 & Winter + summer \\
\hline B-5 & $\mathrm{D}$ & Sanger & 127 & 1950 & 2 & 8 & Summer \\
\hline B-6 & E & Sacramento & 2 & 1333 & 2 & 6 & Summer \\
\hline B-7 & E & Sacramento & 27 & 1333 & 2 & 6 & Winter \\
\hline B-8 & $\mathrm{F}$ & El Dorado Hills & 293 & 4157 & 2 & 6 & DSA test only \\
\hline B-9 & $\mathrm{F}$ & El Dorado Hills & 295 & 3190 & 1 & 6 & DSA test only \\
\hline \multicolumn{8}{|c|}{ Advanced HPD Test Sites } \\
\hline A-1 & $\mathrm{C}-1$ & Fresno & 24 & 1870 & 1 & 8 & Winter + summer \\
\hline A-2 & E-5 & Sacramento & 27 & 1333 & 2 & 8 & Winter + summer \\
\hline A-3 & G-4 & El Dorado Hills & 410 & 3785 & 2 & 6 & Winter + summer \\
\hline A-4 & G-4 & El Dorado Hills & 576 & 2762 & 1 & 6 & Winter + summer \\
\hline A-5 & $\mathrm{H}-3$ & Anderson & 15 & 2205 & 1 & 6 & Summer \\
\hline A-6 & D-2 & Sanger & 154 & 1698 & 1 & 6 & $\begin{array}{l}\text { Duct surface area } \\
\text { and duct leakage } \\
\text { tests only }\end{array}$ \\
\hline A-7 & $\mathrm{D}-2$ & Sanger & 149 & 1816 & 1 & 6 & $\begin{array}{l}\text { Duct surface area } \\
\text { and duct leakage } \\
\text { tests only }\end{array}$ \\
\hline
\end{tabular}




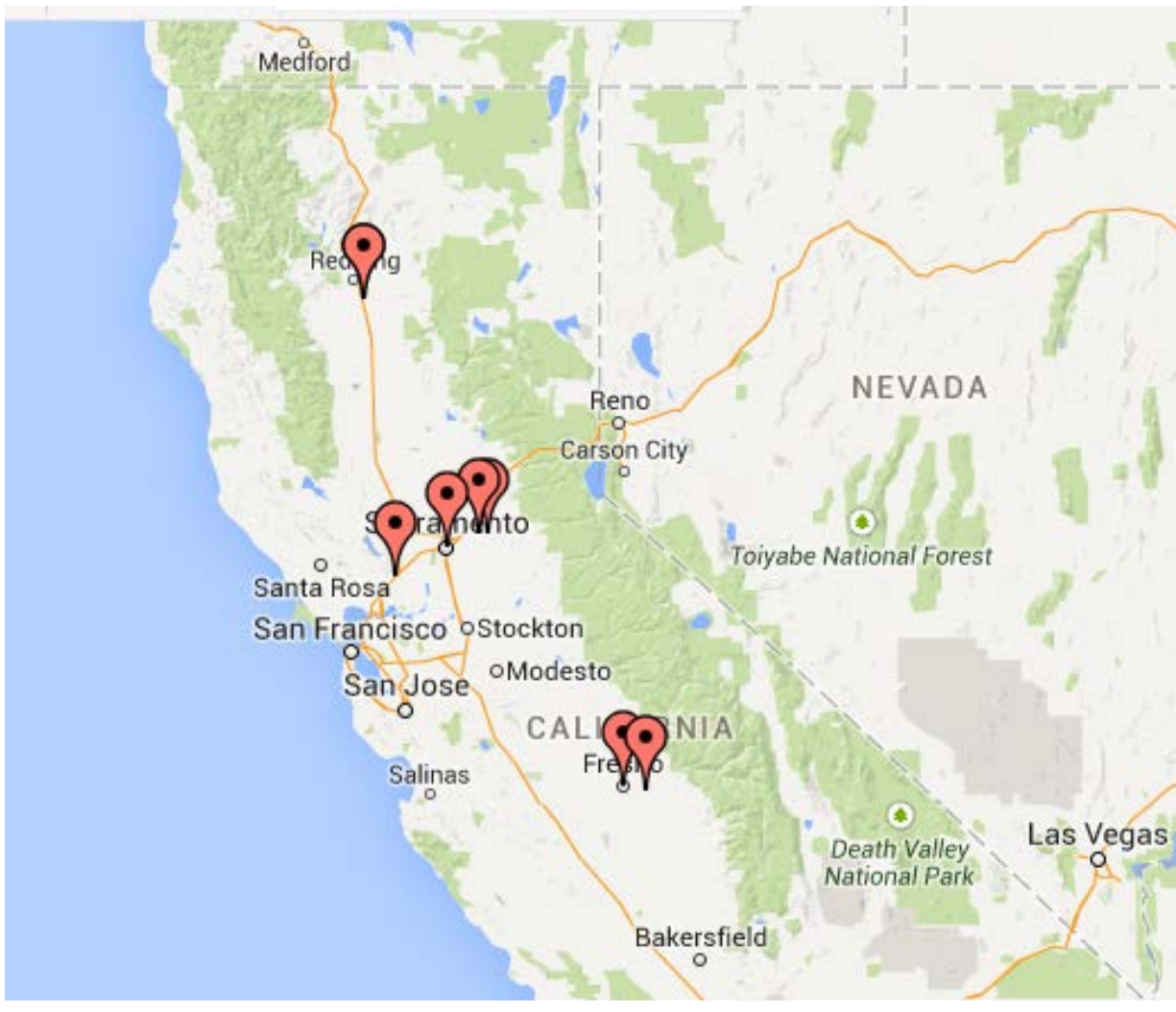

Figure 2. Locations of field sites

\subsection{Field Data Collection}

The field data collection process included the following activities:

- Site inspections during construction (before the sheetrock was installed) to gather detailed data about the installed system, including indoor HVAC equipment specifications, supply and return plenum dimensions, and supply and return duct system characterization (length, duct location, diameter or rectangular dimensions, and R-value for each element of the duct system). This information was used to define inputs for Standard 152 calculations.

- Diagnostic testing of the completed HVAC system installations. This work was completed during summer or winter periods when differences between delivered air and attic air were significant to better detect thermal exchanges. The timing depended upon the house completion schedule and availability after occupancy.

- Postconstruction debriefing of the builders to obtain cost information and general feedback about the implementation process and future improvements.

In addition to these measurements and information, notes and photographs were taken to document installation details that might contribute to the overall HVAC system performance. The periodic visits required much coordination with builders and site superintendents to ensure proper timing so observations could be made before ducts were concealed by drywall. Site visits, meetings, and communications with builders and contractors provided vehicles to gather information about incremental costs and implementation barriers, as well as other anecdotal information. 


\subsection{Project Coordination}

DEG coordinated with PG\&E to execute builder access agreements and facilitated payment of the builder incentives. DEG also hosted bimonthly project calls with PG\&E and other participants, conducted meetings with builders, coordinated site inspections, and reviewed field data. DEG worked closely with the firm TRC to support its prerulemaking activities related to DCS for the 2016 Title 24 cycle (CEC 2015).

\subsection{Evaluation Methods}

\subsubsection{General Approach}

The evaluation approach included quantitative data gathering and analysis and qualitative performance assessments that were based on field observations and builder feedback. Quantifying the DE of DCS and other HPD system strategies involved field diagnostic procedures to capture data that were used to calculate DE using the Standard 152 methodology and for BEopt modeling of the various duct configurations. The following sections detail the methods employed.

\subsubsection{Field Duct Delivery Effectiveness Evaluation}

Duct DE as defined in Standard 152 is the ratio of thermal energy transferred to or from the conditioned space to the thermal energy transferred at the equipment heat exchanger. This standard provides the calculation methods for the design and seasonal DE of residential distribution systems, including forced-air, hydronic, and electric radiant systems. The design DE is calculated at ASHRAE winter and summer design conditions for the selected climate; the seasonal DE is intended to represent full season heating and cooling performance (Table 6). For forced-air cooling and heating systems, the DE equations are listed in Equations 1 and 2.

$$
\begin{gathered}
D E_{\text {Cool }}=\frac{a_{s} Q_{e} \rho_{\text {in }}}{E_{\text {cap }}}\left(\frac{E_{\text {cap }}}{Q_{e} \rho_{\text {in }}}+\left(1-a_{r}\right)\left(h_{a m b, r}-h_{\text {in }}\right)+a_{r} C_{p}\left(B_{r}-1\right) \Delta t_{r}+C_{p}\left(B_{s}-1\right)\left(t_{s p}+t_{a m b, s}\right)\right) \\
D E_{\text {Heat }}=a_{s} B_{s}-a_{s} B_{s}\left(1-B_{r} a_{r}\right) \frac{\Delta t_{r}}{\Delta t_{e}}-a_{s}\left(1-B_{s}\right) \frac{\Delta t_{s}}{\Delta t_{e}}
\end{gathered}
$$

Where

$a_{s}, a_{r} \quad$ represents the leakage factors for the supply and return ducts

$B_{s}, B_{r} \quad$ represents the supply and return conduction fractions

$Q_{e} \quad$ is the system airflow (CFM)

$E_{c a p}$ is the system capacity $(\mathrm{Btu} / \mathrm{h})$

${ }_{C p} \quad$ is the specific heat of air $\left(\mathrm{Btu} / \mathrm{lb}-{ }^{\circ} \mathrm{F}\right)$

$t_{s p} \quad$ is the supply plenum air temperature $\left({ }^{\circ} \mathrm{F}\right)$

$t_{a m b, s}$ is the ambient temperature surrounding the supply ducts $\left({ }^{\circ} \mathrm{F}\right)$

$h_{a m b, r}$ is the enthalpy of the ambient return air $(\mathrm{Btu} / \mathrm{lb})$

$h_{\text {in }} \quad$ is the enthalpy of the conditioned space (Btu/lb)

$\Delta t_{s} \quad$ is the difference between building and ambient temperature surrounding the supply registers $\left({ }^{\circ} \mathrm{F}\right)$

$\Delta t_{r} \quad$ is the difference between building and ambient temperature surrounding the return registers $\left({ }^{\circ} \mathrm{F}\right)$

$\Delta t_{e} \quad$ is the calculated temperature rise across the furnace $\left({ }^{\circ} \mathrm{F}\right)$ 
Table 6. Standard 152 DE Calculation Inputs

\begin{tabular}{|c|c|c|}
\hline Input & Source & Assumption \\
\hline Site Location & Plans & $\begin{array}{l}\text { Nearest representative zone selected from } \\
\text { Standard } 152 \text { Table } 6.3 \mathrm{~b}\end{array}$ \\
\hline Number of Stories & Plans & \\
\hline Conditioned Floor Area $\left(\mathrm{ft}^{2}\right)$ & Plans & \\
\hline Average Ceiling Height & Plans & \\
\hline Attic Venting & Plans & Vented or not vented \\
\hline $\begin{array}{l}\text { Equipment Heating and } \\
\text { Cooling Capacity }\end{array}$ & $\begin{array}{l}\text { Equipment } \\
\text { rating }\end{array}$ & Field observed \\
\hline Equipment speeds & Equipment & Field observed \\
\hline Number of return registers & plans & Field observed \\
\hline $\begin{array}{l}\text { Supply and Return Duct } \\
\text { Surface Area }\left(\mathrm{ft}^{2}\right)\end{array}$ & Plans & Field measured \\
\hline $\begin{array}{l}\text { Fraction of Supply and } \\
\text { Return Ducts Outside } \\
\text { Conditioned Space }\end{array}$ & $\begin{array}{c}\text { Plans, } \\
\text { measurement }\end{array}$ & Field measured \\
\hline $\begin{array}{l}\text { Supply and Return Duct R } \\
\text { Value (h-ft }{ }^{2-{ }^{-}} \text {F/Btu) }\end{array}$ & Plans & Field observed \\
\hline $\begin{array}{l}\text { Heating and Cooling Design } \\
\text { Temperatures }\end{array}$ & & $\begin{array}{l}\text { Nearest representative zone selected from } \\
\text { Standard } 152 \text { Table } 6.3 \mathrm{a}\end{array}$ \\
\hline $\begin{array}{c}\text { Heating and Cooling Seasonal } \\
\text { Temperatures }\end{array}$ & $\begin{array}{c}\text { ASHRAE } \\
\text { table or } \\
\text { measurement }\end{array}$ & $\begin{array}{c}\text { For single point DE, the attic (or duct location) } \\
\text { temperature and zone temperatures were } \\
\text { measured; for seasonal DE, Standard } 152 \text { Table } \\
6.3 \mathrm{~b} \text { was used }\end{array}$ \\
\hline $\begin{array}{l}\text { Design and Seasonal Indoor } \\
\text { and Outdoor Humidity Ratio }\end{array}$ & $\begin{array}{l}\text { ASHRAE } \\
\text { Table }\end{array}$ & $\begin{array}{c}\text { Nearest representative zone selected for Standard } \\
152 \text { Table } 6.3 \mathrm{~b} \text {; the humidity was not measured } \\
\text { during site inspections, the table value was used as } \\
\text { a proxy }\end{array}$ \\
\hline $\begin{array}{l}\text { Heating and Cooling Supply } \\
\text { Fan Flow (CFM) }\end{array}$ & Measurement & Field measured \\
\hline $\begin{array}{l}\text { Heating and Cooling Supply } \\
\text { and Return duct Leakages } \\
\text { (CFM) }\end{array}$ & $\begin{array}{l}\text { Calculation } \\
\text { from } \\
\text { measurement }\end{array}$ & $\begin{array}{l}\text { Calculated using the half nelson technique } \\
\text { (described in Appendix B) }\end{array}$ \\
\hline
\end{tabular}

A spreadsheet utility that applies the Standard 152 calculations $^{7}$ was used to derive the design and seasonal DE of the tested duct systems. Field-measured takeoffs (Table 6) were used as inputs. One-time measurements of house and duct leakage rates, zone, supply and return temperatures, relative humidity, airflow rate, and duct environment temperatures were also made. Climate-specific tables in the standard supplied the inputs that were necessary to determine the design and seasonal duct DE.

The Standard 152 calculation assumes all losses to conditioned space represent useful delivered energy. In conditioned attics and chases within conditioned space, these elements are within the conditioned envelope but not recognized as habitable space. Additional duct thermal

\footnotetext{
${ }^{7}$ The spreadsheet is available at http://www1.eere.energy.gov/buildings/residential/ba analysis_spreadsheets.html.
} 
measurements taken during the field test allowed for calculation of an "observed" DE (ODE) ${ }^{8}$ that uses the field procedure outlined in the 2002 Siegel paper, which compares Standard 152 calculations to field measurements. Under this ODE approach, temperature measurements at the supply plenum and corresponding supply register temperatures were measured and combined with airflow to determine an overall measured DE. The measured system capacity, which was calculated from the supply and return temperatures and system airflow, was also used in place of the rated system capacity. The ODE calculation is represented by Equation 3.

$$
\text { ODE }=\frac{\sum_{i} 60 Q_{i} \rho_{i}\left(h_{i}-h_{\text {in }}\right)}{E_{c a p}}
$$

Where

$Q_{i} \quad$ is the system airflow (CFM)

$\rho_{i} \quad$ is the density of the supply air

$h_{i} \quad$ is the enthalpy of the supply air at each register $(\mathrm{Btu} / \mathrm{lb})$

$h_{\text {in }} \quad$ is the enthalpy of the indoor air $(\mathrm{Btu} / \mathrm{lb})$

$E_{\text {cap }} \quad$ is the system capacity $(\mathrm{Btu} / \mathrm{h})$

$\mathrm{Cp} \quad$ is the specific heat of air $\left(\mathrm{Btu} / \mathrm{lb}-{ }^{\circ} \mathrm{F}\right)$

where Ecap $=60 Q_{i} \rho_{i} c_{p}\left(T_{i}-T_{i n}\right)$

\subsubsection{Uncertainty Analysis}

Rick Chitwood used the test equipment identified in Table 7 (during the manufacturer's calibration period) to complete the diagnostic field measurements. The total uncertainty of the DE calculation includes the individual measurement accuracies and the relationship of the measurements to the overall calculation. The measurement accuracy is influenced by instrument accuracy and the method of data acquisition. The procedure for collecting the measurements followed standard whole-house diagnostic testing procedures.

Table 7. Diagnostic Equipment Used in Field Testing

\begin{tabular}{|c|c|c|}
\hline Device & Make and Model Number & Accuracy \\
\hline $\begin{array}{c}\text { Handheld Digital Thermometer } \\
\text { for Duct Temperature } \\
\text { Measurements }\end{array}$ & Fluke 52 II, T-type thermocouple & $\pm 0.05 \%+0.3^{\circ} \mathrm{C}$ \\
\hline TrueFlow AHU Flow Meter & $\begin{array}{c}\text { TEC TrueFlow with DG-700 digital } \\
\text { pressure gauge }\end{array}$ & $\pm 7 \%$ \\
\hline $\begin{array}{l}\text { Supply Grille Flow } \\
\text { Measurement }\end{array}$ & TEC Flow Blaster & $\begin{array}{c} \pm 5 \% \text { of indicated flow or } \\
\pm 2 \text { CFM, } \\
\text { whichever is greater }\end{array}$ \\
\hline $\begin{array}{l}\text { Duct Blaster Duct } \\
\text { Pressurization Device }\end{array}$ & $\begin{array}{l}\text { TEC DuctBlaster (Series B) with } \\
\text { DG-700 digital pressure gauge }\end{array}$ & $\begin{array}{c} \pm 3 \% \text { of indicated flow or } \\
\pm 1 \text { CFM, } \\
\text { whichever is greater }\end{array}$ \\
\hline $\begin{array}{l}\text { Blower Door for Envelope } \\
\text { Leakage and Duct Leakage to } \\
\text { Outside (DLO) Test }\end{array}$ & $\begin{array}{l}\text { TEC Blower Door Model } 3 \text { with DG- } \\
700 \text { digital pressure gauge }\end{array}$ & $\begin{array}{c} \pm 3 \% \text { of indicated flow } \\
( \pm 4 \% \text { or } 1 \text { CFM for rings } \\
\text { D and E) }\end{array}$ \\
\hline Duct Length & Tape Measure & $\pm 3 \%$ \\
\hline
\end{tabular}

${ }^{8}$ The key distinction is that the observed DE indicates delivery to a supply register rather than just delivery to conditioned space. 
The combined uncertainty in the DE calculation was determined using the delta method. Because each measurement was independently obtained, no mutual influence is expected. The uncertainty is shown in Equation 4:

$$
U_{R}=\sqrt{\sum\left(\frac{\delta R}{\delta x_{i}} u_{x_{i}}\right)^{2}}
$$

Where

$\frac{\delta R}{\delta x_{i}}$ is the partial derivative of the DE calculation with respect to the measured variable and

$u_{x_{i}}$ is the instrument accuracy of the measured variable

The equations were entered into the Engineering Equation Solver software program, because the Standard 152 DE calculation involves many steps. Overall, the Energy Equation Solver determined the uncertainty in the Standard $152 \mathrm{DE}$ calculation to be lower than $0.5 \%$. The uncertainty is low because most measurements were not directly used in the final DE calculation and the instruments used were highly accurate. Also, assumptions imbedded within the Standard 152 methodology that affect the calculated DE are fixed values and tend to diminish the overall calculated uncertainty. The terms that most influence the DE calculation are the duct leakage factors (ar, as) and the conduction terms (Br, Bs). A combination of larger DSA, lower insulation $R$ values, and increased duct leakage (as a percentage of total system airflow) all contribute to lower DE.

The calculation of ODE (Equation 4) is based heavily on the individual supply temperature and airflow measurements. The uncertainty in the DE is $7.2 \%$, because the airflow and temperature measurement accuracies are significant.

\subsubsection{BEopt Modeling}

BEopt v2.3 was used to compare the performance of the various duct system strategies and to evaluate annual energy use impacts relative to the Building America Benchmark in hot-dry climates. This analysis was used to predict heating and cooling site and source energy use, envelope loads, and distribution losses for each case.

Details follow for the characteristic and BEopt inputs for the evaluated strategies. In all cases except the HPA, the roof style is a hip roof, duct insulation is R-8, and total duct leakage is $6 \%$ of system airflow. ${ }^{9}$ The HPA has $5 \%$ duct leakage (per the prescriptive specification in the California 2016 Title-24 standards).

- DCS: Dropped-ceiling and attic chase configurations. BEopt evaluates these two methods in the same manner by eliminating all duct distribution losses to unconditioned space. The AHU is in conditioned space.

\footnotetext{
${ }^{9}$ Duct leakage is based on a percentage of total system airflow to represent the metric that BEopt uses as an input as well as that used to set leakage targets in California's Title-24 energy code. ENERGY STAR requirements are based on conditioned floor area and require no more than 8 CFM25 total leakage per $100 \mathrm{ft}^{2}$ of floor area. As a reference for the 2,100- $\mathrm{ft}^{2}$ prototype evaluated in this study, the total leakage requirement per ENERGY STAR is 168 CFM25. Assuming a 3 -ton air conditioner and $400 \mathrm{cfm} /$ ton, the $6 \%$ target allows no more than 72 CFM 25 .
} 
- NVA: R-30 insulation at the roof level. ${ }^{10}$ The ducts and AHU are in the attic.

- HPA: Vented attic with R-15 insulation under the roof deck and 5\% duct leakage. The ducts and AHU are in the attic.

- DBD: Minimum 3-1/2-in. insulation coverage over ductwork (meets ZERH requirements for dry climates) achieved with R-60 ceiling insulation and R-20 effective duct insulation. ${ }^{11}$ The ducts and AHU are in the attic.

Gable and hip roofs were evaluated for the NVA case. About one-third of the NVA homes built by Meritage Homes use gable roofs, and the attic walls are insulated to the same level as the other exterior walls. This insulation results in a lower average attic assembly R-value than for hip roofs.

\subsubsection{Climates Evaluated}

The four hot-dry western climates characterized in Table 8 were evaluated. These locations provide a good cross-section of climates with extremely hot to moderately hot summers and climates with moderately cold to relatively cold winters.

Table 8. Climate Details of Locations Used in Analysis

\begin{tabular}{c|c|c|c|c}
\hline Location & $\begin{array}{c}\text { International Energy } \\
\text { Conservation Code } \\
\text { Climate Zone }\end{array}$ & $\begin{array}{c}\text { Annual } \\
\mathbf{H D D}^{\mathbf{a}, \mathbf{b}}\end{array}$ & $\begin{array}{c}\text { Annual } \\
\mathbf{C D D}^{\mathbf{a}, \mathbf{b}}\end{array}$ & $\begin{array}{c}\text { Heating/Cooling } \\
\text { Design Temperature }\end{array}$ \\
$\mathbf{( { } ^ { \mathbf { 0 } } \mathbf { F } )}$
\end{tabular}

${ }^{a}$ Heating degree days and cooling degree days were calculated with a base temperature of $65^{\circ} \mathrm{F}$.

${ }^{\mathrm{b}}$ Temperatures were based on $99 \%$ design conditions for heating and $1 \%$ for cooling.

${ }^{c}$ Degree days and design temperatures from the ASHRAE 2013 Fundamentals.

\subsubsection{Houses Evaluated}

Two representative houses were used to evaluate duct performance: a 2,100- $\mathrm{ft}^{2}$ one-story plan and a $2,700-\mathrm{ft}^{2}$ two-story plan. Both were slab-on-grade. The geometry and window areas correspond to the two prototype houses the CEC used to develop and evaluate energy-efficiency measures for the 2013 standards rulemaking process. Window areas are $17.3 \%$ of floor area for the one-story plan and $20 \%$ of floor area for the two-story plan. All building characteristics and schedules follow the Building America Benchmark House Simulation Protocols (Wilson et al. 2014), which are based on the 2009 International Energy Conservation Code. BEopt was used to calculate duct surface area based on floor area (Table 9).

\footnotetext{
${ }^{10}$ With attic sealed to levels tested in a 20-home field survey.

${ }^{11}$ Shapiro et al. (2013) evaluated effective R-values for various buried duct scenarios and calculated an R-value of R-23.5 for an 8-in. R-8 deeply buried duct under fiberglass insulation.
} 
Table 9. Duct Surface Area and Duct Location for Base Case

\begin{tabular}{|c|c|c|}
\hline Orientation & $\begin{array}{c}2,100-\mathrm{ft}^{2} \\
\text { One-Story Plan }\end{array}$ & $\begin{array}{c}2,700-\mathrm{ft}^{2} \\
\text { Two-Story Plan }\end{array}$ \\
\hline Supply Duct Surface Area $\left(\mathrm{ft}^{2}\right)$ & 567 & 547 \\
\hline Return Duct Surface Area $\left(\mathrm{ft}^{2}\right)$ & 210 & 304 \\
\hline \% Duct in Attic & $100 \%$ & $65 \%$ \\
\hline
\end{tabular}

\subsubsection{Distribution System Efficiency}

BEopt does not directly calculate duct efficiencies, but does provide outputs that characterize energy delivered to conditioned space and duct losses. Using that information, distribution system efficiency (DSE) was calculated directly from the BEopt reports. The calculated DSEs will not directly align with the Standard 152 DE calculation or the ODE calculation (Equation 3) that is based on field measurements. Equation 5 defines how DSE was calculated using BEopt results.

$$
\text { DSE [\%] = Energy Delivered }[\text { Btu] } /(\text { Energy Delivered }+ \text { Duct Losses })[B t u]
$$

\subsubsection{Costs for High-Performance Duct Strategies}

Costs were collected from the four participating builders that implemented DCS and NVA strategies and from the one builder who implemented the HPA approach. Obtaining precise costs for integrated measures such as DCS is challenging, because implementing the measure involves multiple subcontractors and significant coordination between trades. Also, when contractors bid on changes to designs for individual "test" houses, costs tend to be much higher than if they bid competitively on a large number of homes. Of the four DCS/NVA builders, two provided sufficiently detailed cost data. Cost data from the other two builders were much less detailed and therefore more anecdotal. 


\section{High-Performance Duct Implementation}

\subsection{Overview}

Of the five participating builders who implemented HPD systems, one applied the NVA strategy, three created attic chases through the trusses above the ceiling level, and one implemented the HPA strategy on a recently completed model home.

\subsection{Nonvented Attic}

Meritage Homes has built with conditioned NVAs for about 4 years and has constructed almost 10,000 homes nationally, with almost 1,000 homes in northern and central California. In California, Meritage uses ocSPF for the entire building envelope, filling the $2 \times 4$ exterior wall cavities with 3.5 in. of ocSPF, and applying R-20 to R-22 insulation to the roof deck underside. (See Figure 3.)

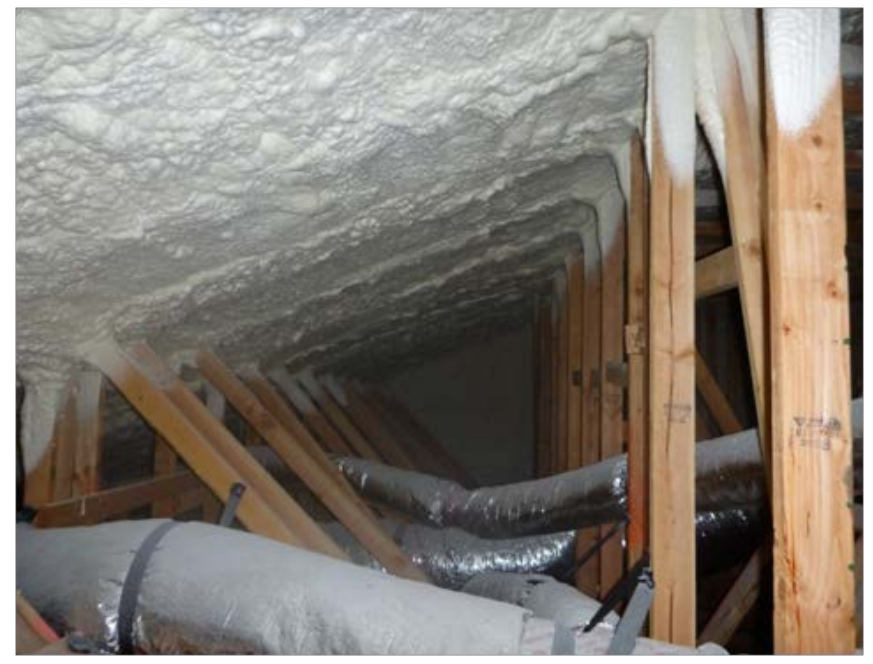

Figure 3. Meritage's NVA with spray-foamed roof deck

According to Northern California regional Planning Manager Mark Eglington, Meritage has experienced no roof deck moisture issues related to ocSPF insulation over that period of time. Although the foamed roof deck costs $\sim \$ 1,500-\$ 1,700$ more $^{12}$ than R-38 blown fiberglass ceiling insulation, Eglington identified several sources of cost savings that are realized in constructing a conditioned attic:

- The air-conditioner capacity can typically be downsized by 0.5 to 1 ton.

- Attic vents in the conditioned attic space are eliminated.

- Minimal additional air-sealing effort is required at the ceiling, because the thermal barrier extends up to the roof deck.

The spray foam process adds about 2 days to the overall house construction schedule, but subcontractors reap clear advantages such as:

\footnotetext{
${ }^{12}$ The builder estimated an additional $\$ 0.75 / \mathrm{ft}^{2}$ to achieve R-30 at the roof deck.
} 
- HVAC system installation procedures are essentially unchanged. ${ }^{13}$

- Equipment is easily accessible for service.

- Few construction complications arise compared to those associated with dropped ceilings and furred-up duct chases.

Meritage's California experience with the conditioned attic technique has garnered very favorable customer satisfaction, according to Eglington. Spray foam in the exterior walls and at the roof deck has resulted in very low-leakage envelopes. Testing during 2014 of 20 Meritage homes in northern California (see Appendix C) showed a median envelope leakage of 1.88 ACH50, or 60\% lower than the median 4.66 ACH50 of 39 single-family homes tested in a 2011 CEC Public Interest Energy Research (PIER) project ${ }^{14}$ (Proctor et al. 2011). Air-conditioner sizing for the same 20 homes was $789 \mathrm{ft}^{2}$ of floor area per ton. This average sizing represents roughly a one-third reduction in cooling capacity relative to the 2011 PIER sample in which the median sizing was $517 \mathrm{ft}^{2} /$ ton. (Chitwood commented that the observed $\mathrm{ft}^{2} /$ ton sizing for the two Meritage homes tested in this project was among the highest he has seen for California production homes.)

Spray foam insulation requires a specialty contractor who is trained in its application. Dan Varvais of Bayer and the Spray Polyurethane Foam Alliance provided insights into the process (personal communications). Typically a three-person crew (sprayer, sprayer helper, and prep person) is required to insulate the walls and roof deck for a 2,000-3,000 $\mathrm{ft}^{2}$ house in a single day. Two crews are needed for a 3,000-4,000 $\mathrm{ft}^{2}$ house. The foam application involves an exothermic reaction; ocSPF reaches $150^{\circ}-160^{\circ} \mathrm{F}$ during application and ccSPF reaches $350^{\circ}-400^{\circ} \mathrm{F}$. (These high temperatures can affect wire insulation, flex duct, and plastic piping. For ccSPF applications, multiple passes may be needed to prevent surfaces from becoming too hot.) A 3.5-in. thickness of ocSPF insulation meets the ASTM E 283 air barrier standard, as does 1 in. of ccSPF. Application is constrained when the substrate or ambient air temperatures are lower than $40^{\circ} \mathrm{F}$ or higher than $120^{\circ} \mathrm{F}$ and relative humidity exceeds $85 \%$. According to Varvais, ocSPF is more commonly used in much of northern and central California. In colder climates such as Lake Tahoe and Reno, ccSPF is often used. In walls this application often involves the "flash and batt" approach wherein a 2-in. layer of spray foam provides the air barrier and fiberglass is used to fill the rest of the wall cavity to reduce cost. An intumescent fire coating is required for ocSPF applications.

\subsection{Ducts in Conditioned Spaces with Attic Chases}

Three participating builders created chases to house the ducts. Project team members held design review meetings with each of the three builders and their HVAC contractors before the designs were finalized. During these meetings implementation options and equipment sizing were discussed, and resources that included Building America Solution Center details were offered. Builder and HVAC contractor concerns, preferences, and design biases were also reviewed. Details and outcomes of these discussions are described for each builder in Section 3.3.1 through Section 3.3.3.

\footnotetext{
${ }^{13}$ Also beneficial for future HVAC servicing because the attic is more thermally neutral and the attic insulation now at the roof deck has minimal impact on attic access.

${ }^{14}$ The 2011 PIER sample represents homes built under the 2005 Title 24 Standards. The current envelope leakage default assumptions under the 2013 Title 24 Standards assume typical house leakage of 5 ACH50.
} 


\subsubsection{Wathen Castanos}

Wathen Castanos is a regional builder in the Fresno area that has long maintained a market strategy of staying 30\% ahead of the Title 24 energy code. This builder has been building to ENERGY STAR ${ }^{\circledR}$ but discontinued that effort because the changes in version 3 were perceived to be too cumbersome and at \$300-\$500 extra per house too costly. Instead the builder adopted its own branding. Wathen Castanos sees its clientele as financially conservative and as having fairly high comfort expectations but no particular interest in energy efficiency.

In a July 2013 design review meeting with the project team, equipment and ducting options for an $1,870-\mathrm{ft}^{2}$ single-story plan were discussed. Options included mini-splits with ceiling-mounted ducted AHUs, split-system heat pumps with "pancake" ceiling- or closet-mounted AHUs, and combined hydronic systems. Despite concerns expressed by Rick Chitwood that the smallest available furnace would be substantially oversized, the builder opted for a conventional gas furnace/split-system air conditioner. The builder and HVAC contractor were sensitive to meeting high comfort expectations and were reluctant to follow more aggressive HVAC equipment rightsizing protocols.

Chitwood recommended furring down or dropping ceilings to create duct chases and using a compact duct system with an interior mechanical closet. The builder rejected these ideas. The primary concerns were the aesthetics of lowered ceilings in hallways and equipment noise. The HVAC contractor lacked confidence that a compact duct design could achieve adequate throw and mixing. Though the builder was receptive to the compact duct approach, its hands were tied by the need to preserve its longtime relationship with the contractor. The Wathan-Castanos team opted to create an attic mechanical space for the equipment and duct chases constructed through the trusses, believing the added cost would be \$400-\$500. Methods for lining and sealing duct cavities were discussed, including alternatives that would avoid having the drywall contractors make two trips. One approach was to have framers line the chases with OSB or THERMO-PLY and insulators to seal cracks with foam. The HVAC contractor expressed concerns about whether an effective seal could be created between the drywall and the OSB. The ultimate design included 22-in. wide and 22-in. tall duct chases lined with drywall to house R-8 ducts (Figure 4). 


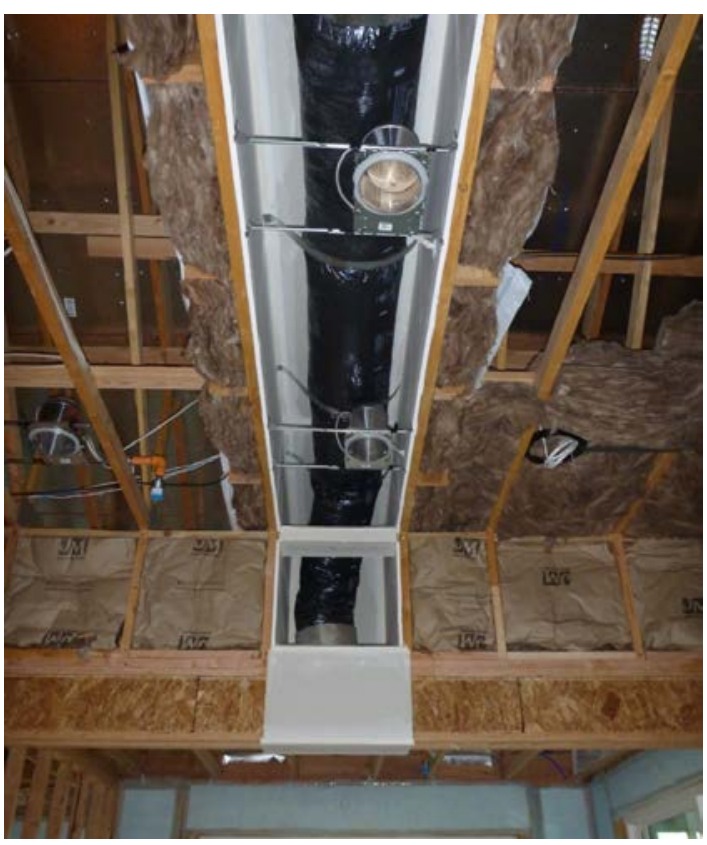

Figure 4. Drywall-lined duct chase in the Wathan Castanos house

The attic chases for ducting and an attic room for the mechanical equipment significantly increased the home's thermal enclosure surface area. The sides of the chases had to be treated like attic knee walls and were difficult to insulate. Figure 5 shows attic-side and interior views of the mechanical closet during construction. Figure 6 shows a plan of the house with the duct chases layout and attic mechanical room ("doghouse"). The original planning estimate of $\$ 400$ $\$ 500$ grew to an estimated final construction cost for the doghouse and duct chases of nearly $\$ 9,000$.
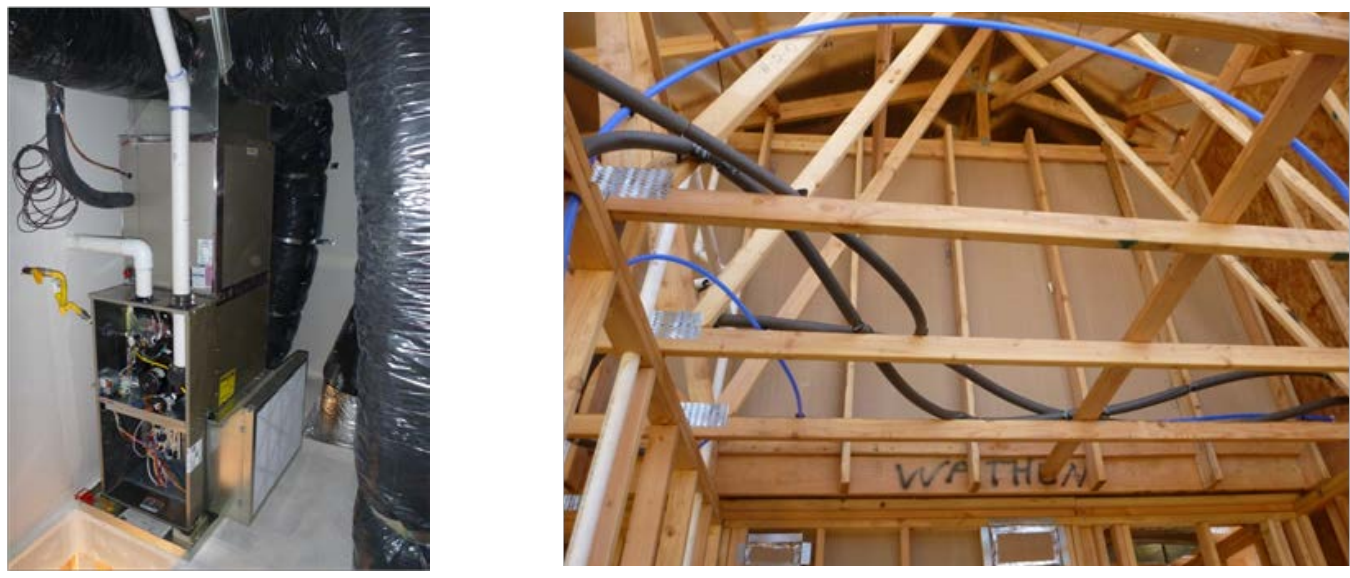

Figure 5. Attic mechanical closet viewed from inside (left) and outside (right) 


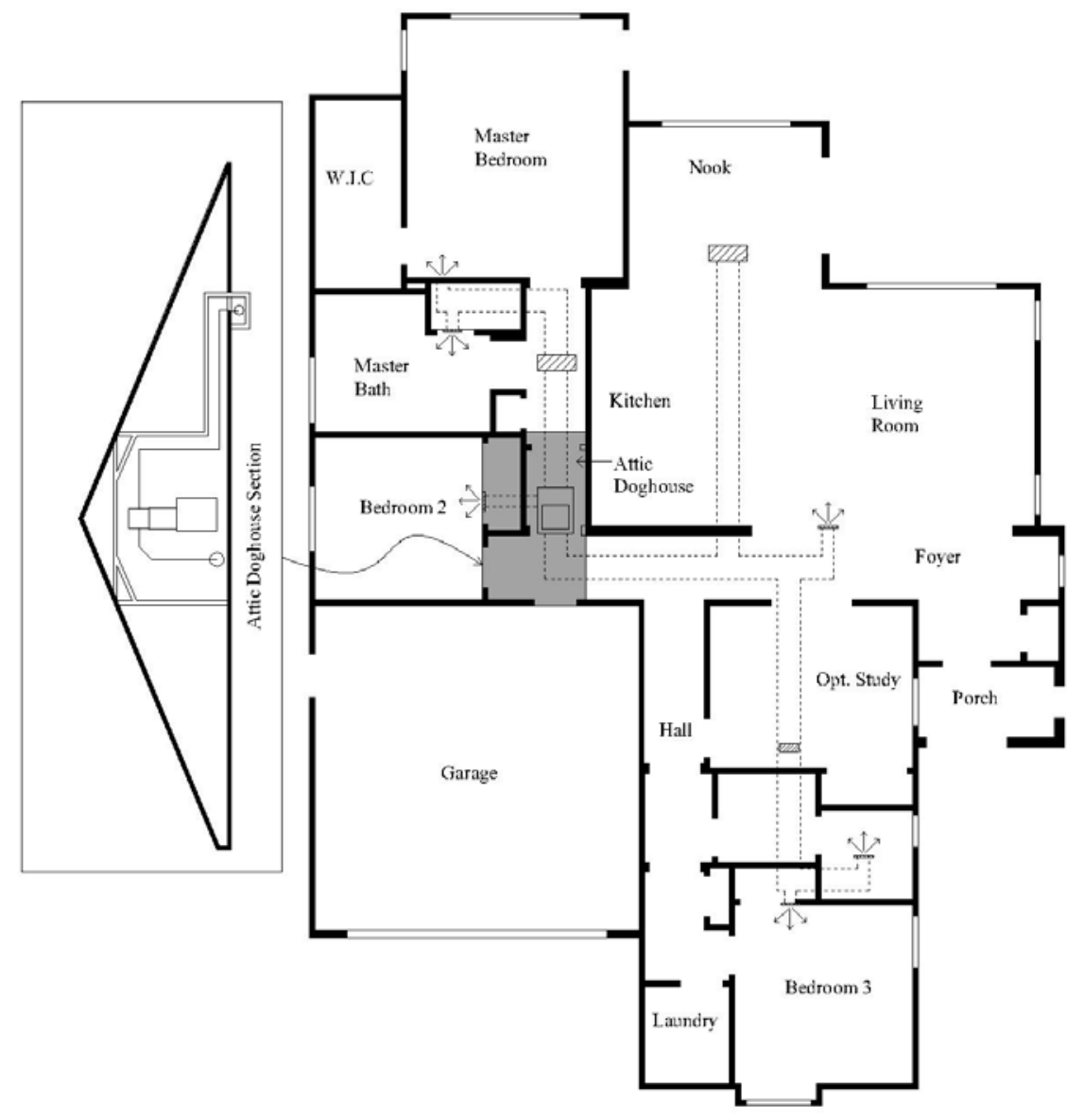

Figure 6. Wathen Castanos $1,870-\mathrm{ft}^{2}$ plan attic mechanical closet (shaded) and duct chases

\subsubsection{G.J. Gardner}

G.J. Gardner is an international company with more than 110 franchises that operate throughout Australia, New Zealand, and the United States. Its Fresno/Kingsburg franchise serves south Fresno County, including Sanger where the site was selected for a DCS house. G.J. Gardner was one of the first builders that agreed to participate in the PG\&E project. The builder expressed an interest in integrating DCS and high-performance walls ${ }^{15}$ into its designs, which already exceeded Title 24 performance levels by 20\%-30\%. PG\&E and Building America support provided an opportunity to obtain design assistance and to earn incentives on two planned homes. G.J. Gardner's commitment to these measures was evidenced by its decision to include the two advanced measures in all 155 homes it plans to build in the Sanger subdivision. Unfortunately, construction delays that were caused by financing and permit problems meant that the final duct system thermal testing could not be completed within the original proposed project timeline. Instead of breaking ground in the fall of 2013, foundation work on the first homes did not begin until late May 2014.

In October 2013 the project team met with G.J. Gardner and its HVAC contractor to review DCS implementation on its existing designs. The builder offered a one-story and a two-story plan

\footnotetext{
${ }^{15}$ High-performance walls were a second component of PG\&E's emerging technology project focused on measures for 2016 Title 24 implementation.
} 
$\left(1,816\right.$ and $1,950 \mathrm{ft}^{2}$, respectively) for testing. G.J. Gardner was willing to commit interior space for a mechanical closet, and even with floor plans as small as $1,700 \mathrm{ft}^{2}$, the builder was not overly concerned about the loss of interior space associated with the mechanical closet. However, it was not receptive to creating a dropped-ceiling duct chase.

With an attic duct chase strategy viewed as the preferred approach, the project team provided suggestions for the duct design based on the truss and architectural constraints. The suggested approach, diagrammed in Figure 7, could have been implemented as either an attic chase or a dropped-ceiling design and included reducing the number of supply registers to avoid multiple registers in the great room and supplies in half baths and the master closet. The HVAC contractor and builder felt strongly that this more compact design approach was not appropriate for its market and developed the ducting design shown in Figure 8.

G.J. Gardner's experiences in implementation were similar to those of Wathan Castanos in that its HVAC contractor was not willing to pursue a more compact (though less costly) duct design. The contractor was also not receptive to downsizing the air conditioner from 3 to 2 tons to be consistent with Manual J sizing, citing its customers' high comfort standards. The team requested pricing on a two-speed system, but the $\$ 500-\$ 600$ incremental cost was more than the builder was willing to invest. G.J. Gardner did achieve a better cost position by planning to implement DCS in all 155 homes in the subdivision. From the builder's perspective, the approximately $\$ 3,000$ higher costs for DCS could be offset by higher incentive payments through the California Advanced Home Program by generating a greater Title 24 compliance margin.

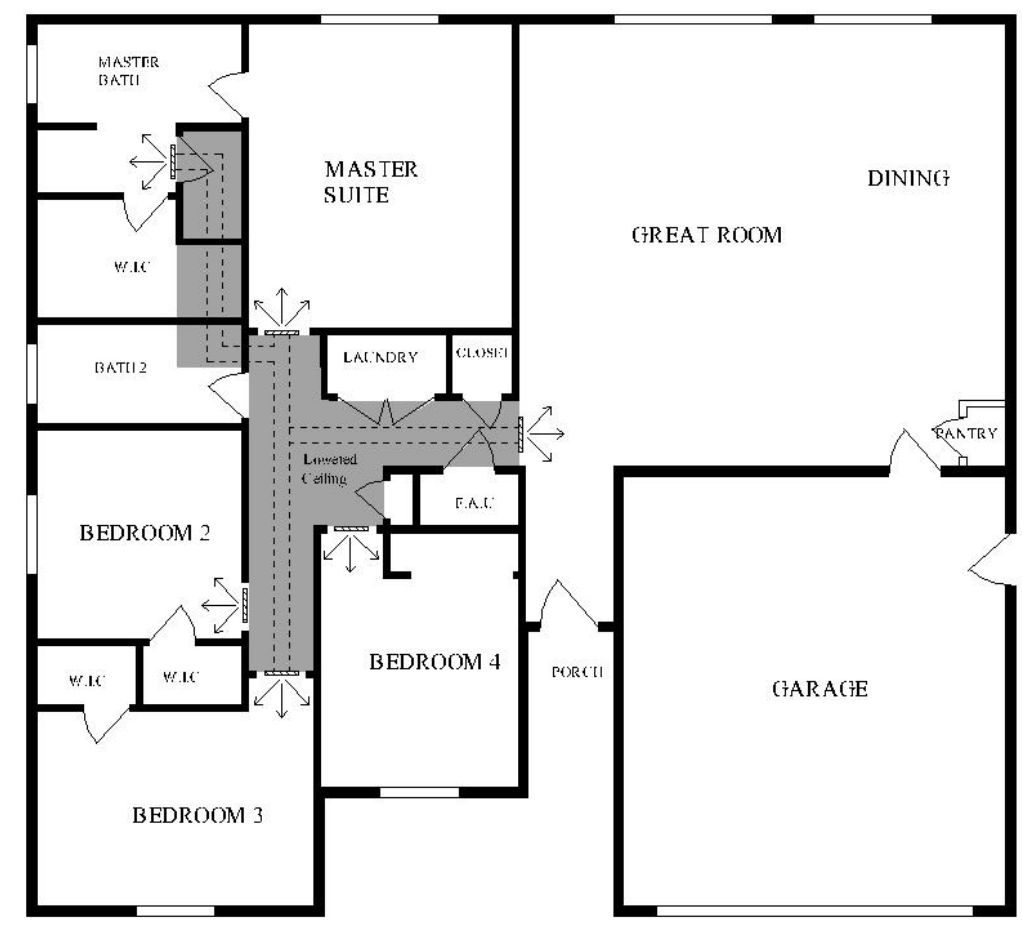

Figure 7. Recommended compact duct design for G.J. Gardner 1,816- $\mathrm{ft}^{2}$ plan 


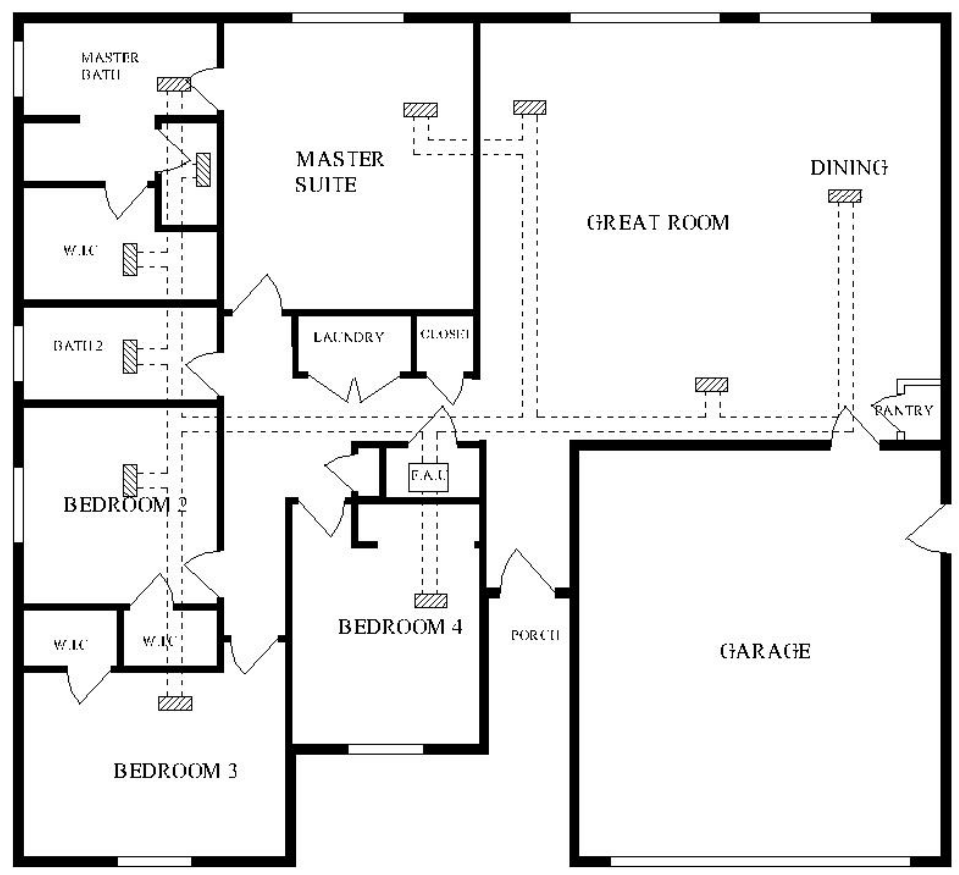

Figure 8. As-built attic duct chases for G.J. Gardner 1,816- $\mathrm{ft}^{2}$ plan

As built, the attic duct chases were 24 in. wide by 28 in. tall. The excessive size added cost and created large vertical surfaces that had to be insulated similarly to knee walls. Constructed of radiant barrier-laminated OSB, attempts were made to seal the chases after the ducts were installed, leaving some gaps unaffected; however, later testing showed that $25 \%$ of duct leakage occurred to unconditioned space. Figure 9 and Figure 10 show details of the attic chase construction on the $1,816-\mathrm{ft}^{2}$ plan.

Figure 11 shows the indoor mechanical closet.

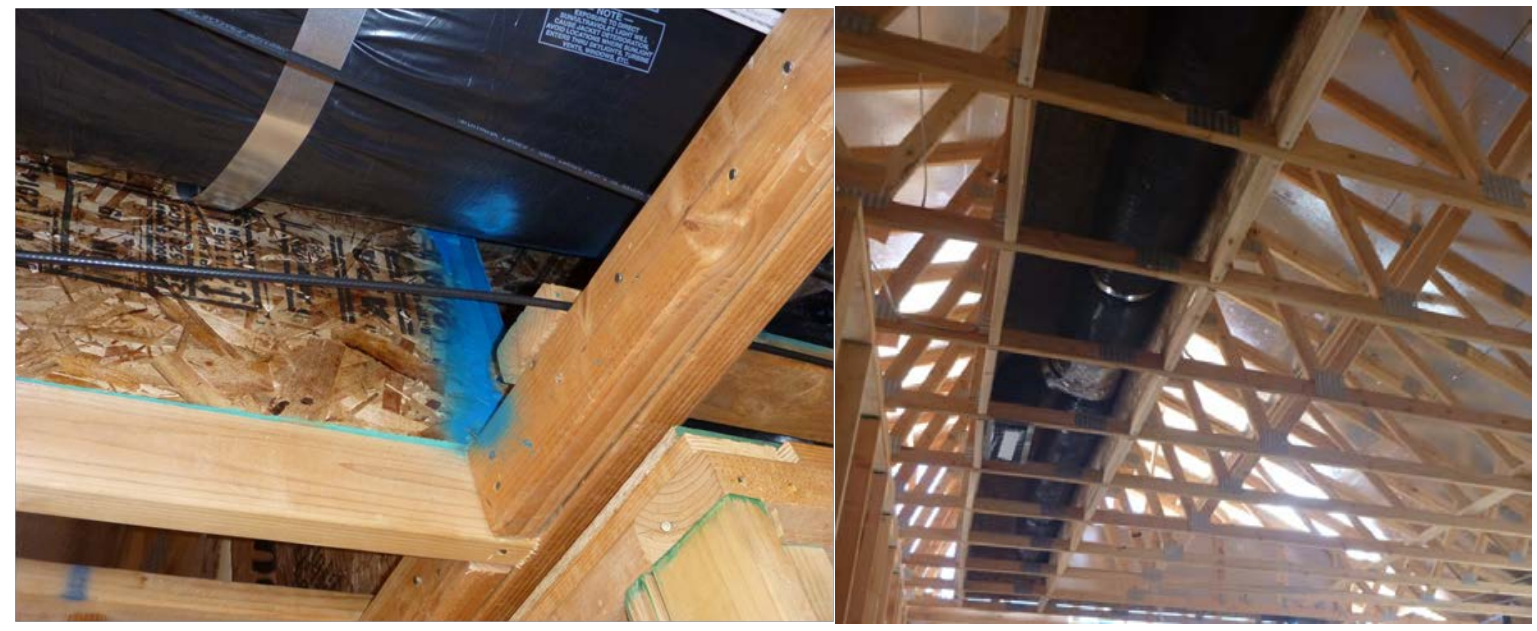

Figure 9. Duct chase in G.J. Gardner home

(The blue material is EcoSeal, used to seal joints in the OSB chase.) 


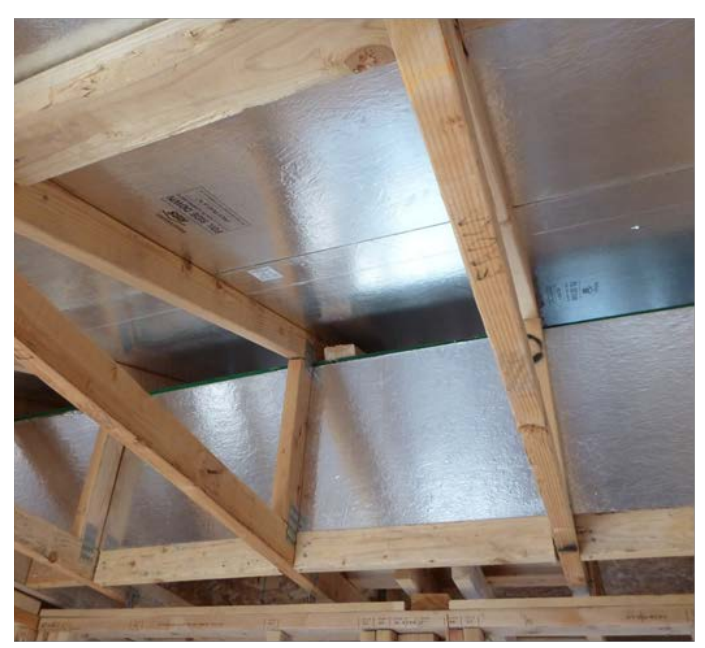

Figure 10. Exterior view of duct chase $\left(1,816-\mathrm{ft}^{2}\right.$ plan)

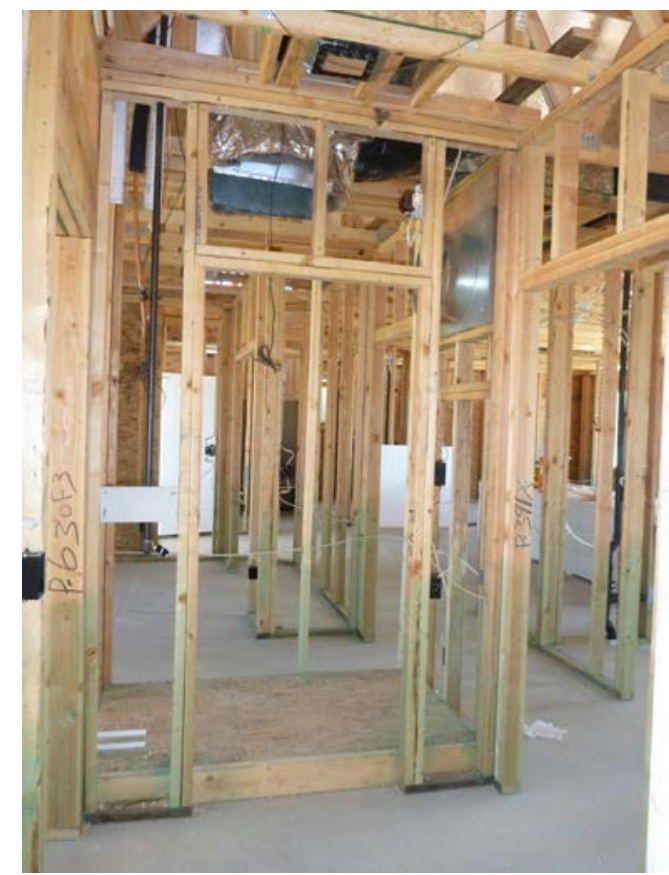

Figure 11. Indoor mechanical closet

\subsubsection{Northwest Homes}

Northwest Homes is a Redding, California, area builder that serves the custom and build-to-suit market. A design review meeting was held on July 26, 2013, with the builder, designer, and HVAC contractor. Project team member Rick Chitwood focused on HPD options for the planned 2,205- $\mathrm{ft}^{2}$ one-story home. Options included using a 10-ft plate height and dropping the hall ceilings to $9 \mathrm{ft}$, use of plenum trusses, a conditioned NVA, and boxed-in attic duct chases installed above the ceiling plane. The builder was very concerned about the design aesthetics associated with dropped ceilings and how these might impact the home's salability. After an extended discussion, the conversation circled back to the dropped-ceiling approach and the decision was made that "... it would probably look fine if we lowered only the hall ceilings." At the end of the meeting this was the agreed-upon strategy and the builder instructed the designer 
to make room for the AHU in a hall closet. Months later and just before construction began, the builder decided to eliminate the lowered ceiling and build attic duct chases. This decision was based on lingering marketing concerns about the dropped-ceiling approach.

The builder expressed a strong preference for gas space heating because of concerns about the impact of heat pump heating on winter utility bills. (PG\&E has a tiered electricity rate schedule and high electricity rates relative to natural gas.) Chitwood advocated for an air-source heat pump as a better solution for a low-load high-performance house, but the builder opted for a condensing gas furnace. A Manual J report Chitwood generated for the house showed that, with the planned energy measures, ${ }^{16}$ a 1.5 -ton air conditioner would be adequate for the $2,205-\mathrm{ft}^{2}$ onestory plan. Both the builder and the HVAC contractor were reticent, but accepted the Manual J sizing if an oversized evaporator coil could be installed. This approach would reduce the cost of potential upsizing, because only the condensing unit would have to be traded out. Without this guidance the contractor would have installed a 4-ton system and yielded to rule-of-thumb sizing of $550 \mathrm{ft}^{2} /$ ton.

Figure 12 shows a plan of the attic duct chase and interior mechanical closet furnace location (denoted as FAU to the left of the Entry). Figure 13 shows views of the ducting and chase and of the indoor mechanical closet.

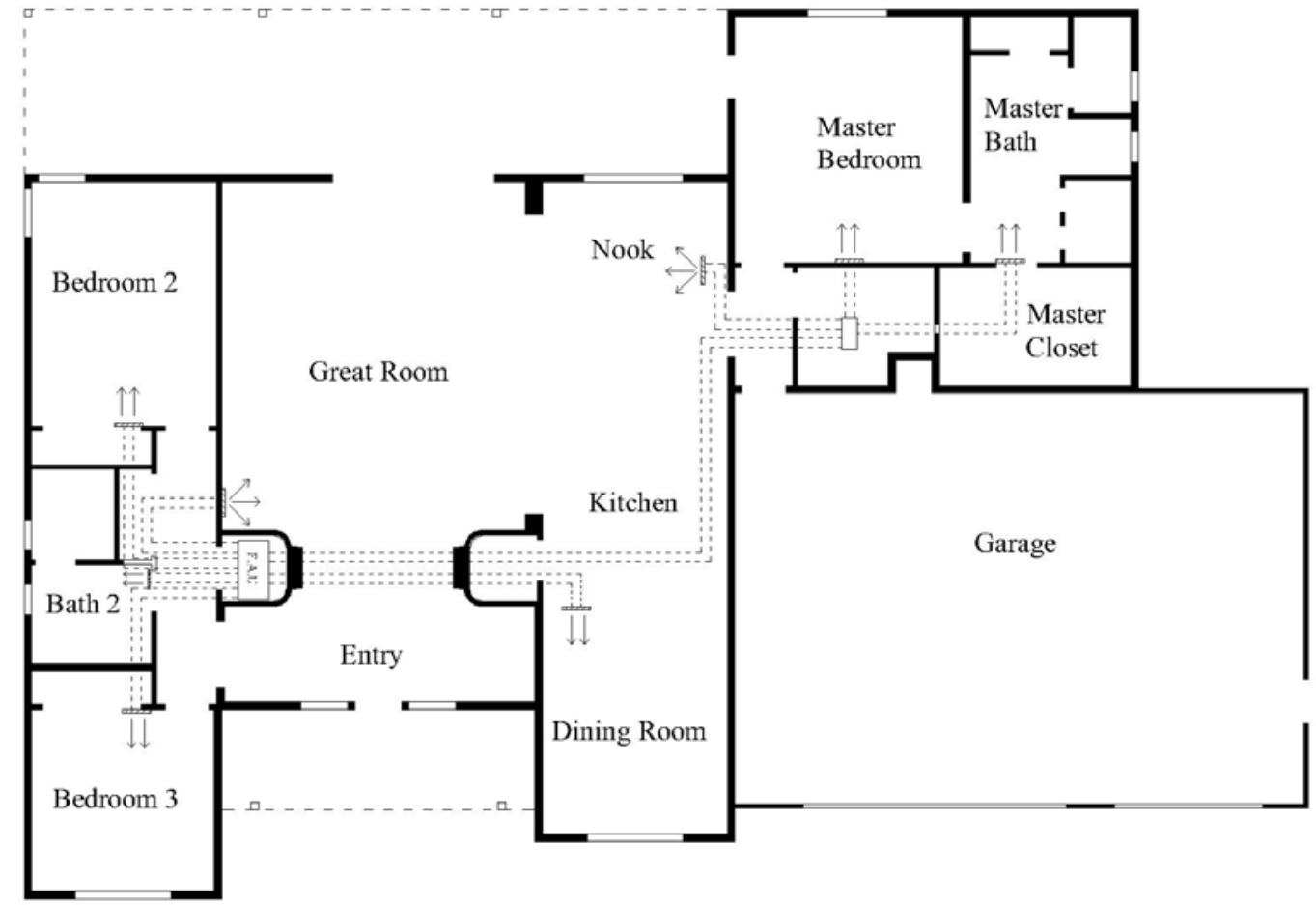

Figure 12. Attic duct chase plan for Northwest Homes 2,205- $\mathrm{ft}^{2}$ plan

\footnotetext{
${ }^{16}$ Included $2 \times 6$ walls with an assembly U-value of $0.050 \mathrm{Btu} / \mathrm{h}-\mathrm{ft}^{2}-{ }^{\circ} \mathrm{F}$, good glazing with low SHGC, and DCS.
} 

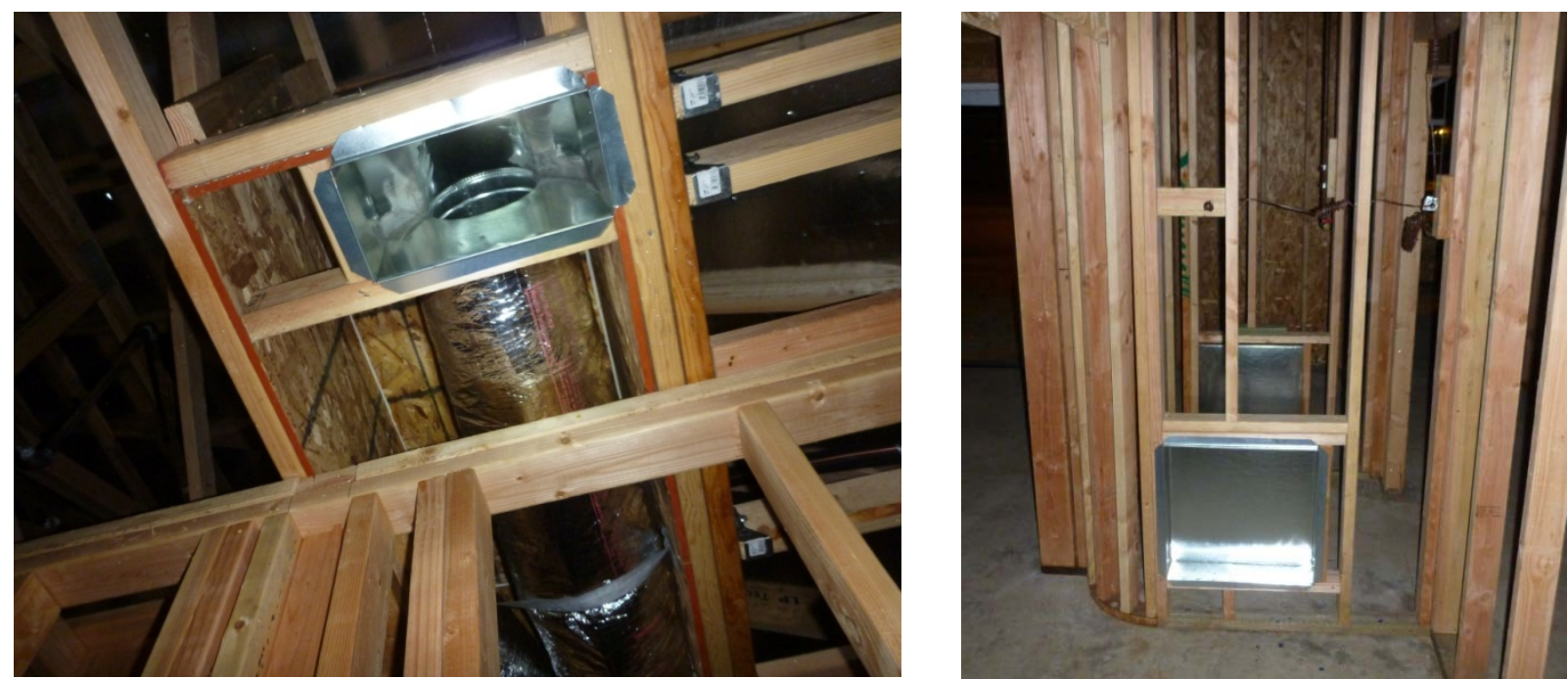

Figure 13. Duct chase and boot for register (left); mechanical closet (right), Northwest Homes 2,205-ft ${ }^{2}$ plan

Northwest Homes postconstruction DCS feedback was generally favorable, although the builder was concerned about the added cost for additional chase framing and air sealing. The framer charges about $\$ 1,500$ /day and estimated an additional day to frame the attic duct chases for this house. The builder's final thought was to take a harder look at using the dropped-ceiling approach as a cost-effective strategy.

One issue noted by Chitwood is that resilient metal channels (which are typically used to meet sound transmission class ratings) were used to attach the ceiling drywall. The channels lowered the drywall about $1 / 2$ in. and created a gap between the bottom of the attic duct chase and the ceiling drywall. This gap was sealed with one part gun foam, but the seal was somewhat ineffective: later duct testing showed that $43 \%$ of the measured 34 CFM25 total duct leakage was to the outside.

The builder marketed the house to potential buyers as a "special energy house" developed in participation with an advanced PG\&E project looking to highlight energy efficiency and measures that will be part of future energy codes. Early reaction from people who saw the home indicated some interest in the energy-efficiency aspect of the design, ${ }^{17}$ but these features were still secondary to the prospective buyers' list of items that they look for in a new home.

The builder was not concerned with the close HVAC sizing (1.5 tons of cooling for a 2,200- $\mathrm{ft}^{2}$ house) given how the house performed during the 2014 summer while it was on the market. He did indicate that education would be necessary to ensure the system provides adequate comfort. In this region many homeowners operate their cooling systems manually and expect to cool their homes rapidly on demand. With rightsized systems, a constant cooling set point must be faithfully maintained to prevent the indoor temperature from "running away" on hot days when the thermostat is turned off or set back.

\footnotetext{
${ }^{17}$ High-performance walls and a high-efficacy LED lighting system were also installed.
} 


\subsection{High-Performance Attics \\ 3.4.1 Pacific Housing}

Pacific Housing is a nonprofit builder that provides affordable housing for lower income California families and seniors. ARBI contacted this builder in the fall of 2013 about a 34-unit infill project being completed in midtown Sacramento. The project targeted about a $40 \%$ improvement over the 2008 Title 24 standards. Through funding support from the Sacramento Municipal Utility District (the local electric utility), the project also integrates photovoltaics and battery storage. Although construction was too advanced to make design changes on any of the units that were still under construction, the builder was open to exploring the HPA strategy on one model home. In late fall 2013, the CEC was in the early stages of defining the exact specification for the HPA approach and was interested in seeing an early implementation of the strategy.

PG\&E expanded the project work scope to allow for a 1,333- $\mathrm{ft}^{2}$ two-story model home to be retrofitted from a conventional vented attic design with R-6 ductwork to an HPA design with R-8 ducts in the vented attic, R-11 batt insulation at the roof deck, and a target duct leakage of $5 \%$ at $25 \mathrm{~Pa}$. Figure 14 shows the attic after ducts were replaced, R-11 batts were added below the roof deck, and blown insulation was reinstalled; the ducts were buried when possible. Testing of the duct system was completed before the retrofit in the heating season and after the retrofit in winter and midsummer.

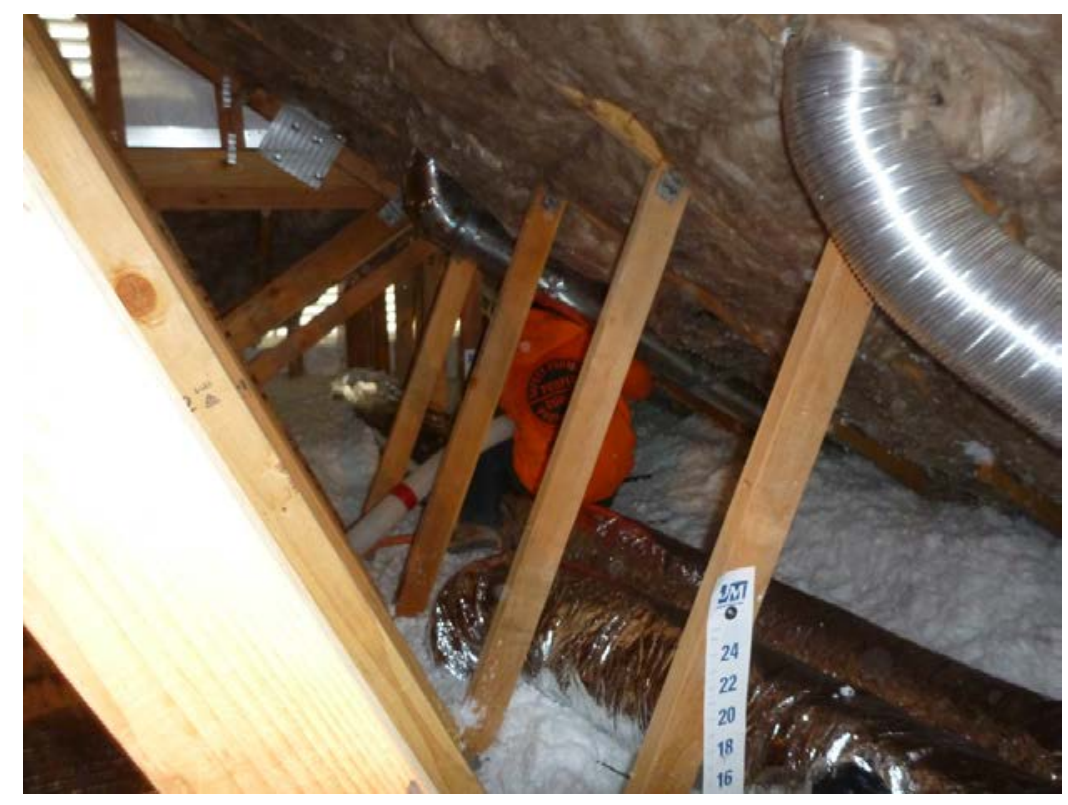

Figure 14. HPA installed in a Pacific Housing unit 


\section{Field Results}

\subsection{Data Collection}

Data were collected from each house for calculating the DE using Standard 152 (see Table 4). Dimensional inputs from each base case (B-) and test house (A-) are provided in Table 10. Sites A-6 and A-7 did not have equipment installed at the time field measurements were taken, as indicated by the "N/A" entry.

Table 10. Test Site Duct Surface Area Measurements

\begin{tabular}{|c|c|c|c|c|c|c|c|}
\hline $\begin{array}{c}\text { Site } \\
\text { ID }\end{array}$ & $\begin{array}{c}\text { Supply } \\
\text { Duct } \\
\text { Surface } \\
\text { Area } \\
\left(\mathbf{f t}^{2}\right)\end{array}$ & $\begin{array}{c}\text { Return } \\
\text { Duct } \\
\text { Surface } \\
\text { Area } \\
\left(\mathbf{f t}^{2}\right)\end{array}$ & $\begin{array}{c}\text { Total } \\
\text { Duct } \\
\text { Surface } \\
\text { Area } \\
\left(\mathbf{f t}^{2}\right)\end{array}$ & $\begin{array}{c}\text { Supply } \\
\text { Plenum } \\
\text { Surface } \\
\text { Area } \\
\left(\mathbf{f t}^{2}\right)\end{array}$ & $\begin{array}{c}\text { Return } \\
\text { Plenum } \\
\text { Surface } \\
\text { Area } \\
\left(\mathbf{f t}^{2}\right)\end{array}$ & $\begin{array}{c}\text { Furnace } \\
\text { Surface } \\
\text { Area } \\
\left(\mathbf{f t t}^{2}\right)\end{array}$ & $\begin{array}{c}\text { Junction } \\
\text { Box } \\
\text { Surface } \\
\text { Area } \\
\left(\mathbf{f t}^{2}\right)\end{array}$ \\
\hline B-1 & 854.5 & 147.5 & 1002.0 & 19.5 & 7.2 & 23.3 & 0 \\
\hline B-2 & 746.4 & 88.0 & 834.4 & 20.2 & 6.7 & 21.6 & 0 \\
\hline B-3 & 405.5 & 117.4 & 522.9 & 24.6 & 16.9 & 35.6 & 7.5 \\
\hline B-4 & 329.3 & 51.8 & 381.1 & 13.1 & 0 & 33.2 & 0 \\
\hline B-5 & 855.9 & 97.9 & 953.8 & 9.7 & 14.5 & 22.5 & 0 \\
\hline B-6 & 490.8 & 54.7 & 545.5 & 8.7 & 12.8 & 28.2 & 0 \\
\hline B-7 & 474.4 & 109.4 & 583.9 & 8.5 & 12.8 & 28.2 & 0 \\
\hline B-8 & 1626.8 & 178.0 & 1804.8 & 27.0 & 20.0 & 23.8 & 0 \\
\hline B-9 & 1295.1 & 181.2 & 1476.3 & 25.9 & 14.9 & 24.3 & 29.7 \\
\hline A-1 & 427.3 & 0 & 427.3 & 8.7 & 0 & 28.4 & 0 \\
\hline A-2 & 538.2 & 51.8 & 590.0 & 8.5 & 12.8 & 28.2 & 0 \\
\hline A-3 & 1565.9 & 197.1 & 1763.1 & 26.2 & 15.4 & 29.9 & 0 \\
\hline A-4 & 586.7 & 190.9 & 777.5 & 13.6 & 14.1 & 27.2 & 0 \\
\hline A-5 & 564.4 & 4.9 & 569.3 & 17.9 & 37.9 & 19.9 & 15.7 \\
\hline A-6 & 424.8 & 0 & 424.8 & $\mathrm{~N} / \mathrm{A}$ & 0 & $\mathrm{~N} / \mathrm{A}$ & 0 \\
\hline A-7 & 435.9 & 0 & 435.9 & $\mathrm{~N} / \mathrm{A}$ & 0 & $\mathrm{~N} / \mathrm{A}$ & 0 \\
\hline
\end{tabular}

Both BEopt and Title 24 compliance software assume one- and two-story homes have supply DSAs that are equal to $27 \%$ of conditioned floor area and return DSAs of $5 \%$ (one-story) and $10 \%$ (two-story). These assumptions represent averages and of course differ from the measured values. For example, the measured surface areas for house A-3 are 35\% higher than the assumed area for the supply ducts and $92 \%$ lower than the assumed area for the return ducts.

Table 11 lists duct location information, airflows, leakage, and other parameters that are required for Standard $152 \mathrm{DE}$ calculations for each test site. Field test results are fully documented in Appendix D. All except one of the base-case tested houses and four of the seven advanced houses have supply DSAs that are larger than the default Standard 152 assumption of $27 \%$ of floor area. 
Table 11. Key Site Collected Parameters for Standard 152 DE Determination

\begin{tabular}{|c|c|c|c|c|c|c|c|}
\hline $\begin{array}{c}\text { Site } \\
\text { ID }\end{array}$ & $\begin{array}{c}\text { Attic } \\
\text { Venting }\end{array}$ & $\begin{array}{c}\text { Duct } \\
\text { Surface } \\
\text { Area } \\
\text { (\% of } \\
\text { Floor } \\
\text { Area) }\end{array}$ & $\begin{array}{l}\text { \% Supply } \\
\text { Ducts in } \\
\text { Conditioned } \\
\text { Space }\end{array}$ & $\begin{array}{c}\text { Installed } \\
\text { Cooling } \\
\text { Capacity } \\
\text { (tons) }\end{array}$ & $\begin{array}{l}\text { Installed } \\
\text { Heating } \\
\text { Capacity } \\
(\mathbf{k B t u} / \mathrm{h})\end{array}$ & $\begin{array}{l}\text { Measured } \\
\text { Cooling } \\
\text { Airflow } \\
\text { (CFM) }\end{array}$ & $\begin{array}{c}\text { Total Duct } \\
\text { Leakage } \\
\text { at } 25 \mathrm{~Pa} / \\
\text { Leakage to } \\
\text { Outside } \\
\text { @ } 25 \mathrm{~Pa}\end{array}$ \\
\hline B-1 & Vented & $39.5 \%$ & $44 \%$ & 4 & 84 & & \\
\hline B-2 & Vented & $36.4 \%$ & $38 \%$ & 4 & 66 & 1,167 & $69 / 46$ \\
\hline B-3 & Vented & $32.2 \%$ & $0 \%$ & 2 & 46 & & \\
\hline B-4 & Vented & $24.3 \%$ & $0 \%$ & 2 & 60 & 762 & $35 / 21$ \\
\hline B-5 & Vented & $50.1 \%$ & $11 \%$ & 4 & 88 & 1,209 & $93 / 76$ \\
\hline B-6 & Vented & $44.8 \%$ & $22 \%$ & 3 & $40^{\mathrm{b}}$ & 1,046 & $46 / 37 b$ \\
\hline B-7 & Vented & $47.8 \%$ & $23 \%$ & 3 & $40^{\mathrm{b}}$ & 934 & $52 / 42$ \\
\hline B-8 & Vented & $44.5 \%$ & $20 \%$ & $\mathrm{~N} / \mathrm{A}$ & $\mathrm{N} / \mathrm{A}$ & $\mathrm{N} / \mathrm{A}$ & N/A \\
\hline B-9 & Vented & $48.5 \%$ & $0 \%$ & N/A & N/A & N/A & N/A \\
\hline A-1 & Vented DCS & $23.3 \%$ & $100 \%$ & 2 & 40 & 869 & $23 /$ “c0" $(<10)^{\mathrm{c}}$ \\
\hline A-2 & Vented HPA & $48.3 \%$ & $20 \%$ & 3 & $40 \mathrm{a}$ & 1,142 & $35 / 22$ \\
\hline A-3 & NVA, Sealed & $48.1 \%$ & $100 \%$ & 4 & 92 & 1,484 & $95 / 0$ \\
\hline A-4 & NVA, Sealed & $29.2 \%$ & $100 \%$ & 3.5 & 92 & 1,042 & $102 / 26$ \\
\hline A-5 & Vented DCS & $29.1 \%$ & $100 \%$ & 1.5 & 40 & 937 & $34 / 15$ \\
\hline A-6 & Vented DCS & $25.0 \%$ & $100 \%$ & 3 & 70 & N/A & $91 / 21$ \\
\hline A-7 & Vented DCS & $24.0 \%$ & $100 \%$ & 3 & 70 & $\mathrm{~N} / \mathrm{A}$ & $108 / 30$ \\
\hline
\end{tabular}

${ }^{a}$ DLO is estimated based on site B-7 because some envelope air leakage tests were not completed.

${ }^{\mathrm{b}}$ Heating capacity for combined hydronic system is estimated.

${ }^{\mathrm{c}}$ Leakage was less than $10 \mathrm{CFM}$.

\subsection{Measured, Design, and Seasonal Delivery Effectiveness}

The ARBI team endeavored to schedule thermal testing during midsummer or midwinter conditions to allow for a large attic-to-duct temperature differences for better measurement resolution and reduced error. This is much more critical for base-case vented attic duct systems, because the advanced systems have ducts within conditioned space. This objective was complicated by construction schedules and house access during the final construction steps and by the normal weather variations that interfered with the best-intended plans. Some sites (B-1, B3, B-8, B-9, A-6, and A-7) could not be tested. Winter tests were targeted for early morning postsunrise hours and summer testing was performed during mid- to late afternoons. Thermostats were set to ensure extended runtimes to allow for stable thermal measurements.

Table 12 summarizes the indoor and attic conditions from the field testing and DEs calculated using Standard 152 with existing temperature conditions and airflow rates.

All base-case houses had vented attics with radiant barrier roof sheathing, and most ducting was in unconditioned space. Site B-4 performed higher than the average, because the duct insulation levels were higher and the duct layout was more compact. Though varying temperature conditions prevent a direct comparison of results, Table 12 data show the advanced systems all performed better than the base-case systems. For the Site A-2 HPA retrofit, many of the R-8 ducts were partially or fully buried, and about $20 \%$ were in conditioned space (interior drops to 
serve the first floor). Site A-5 is a small system with minimal air leakage. It performed slightly worse than the other sites because some duct chases were uninsulated. Also, thermal imaging showed that some sections of the supply chases appear to have been poorly insulated at that site. Site A-5 was also tested on a significantly hotter day, so the DE was lower than was calculated using design conditions.

Table 12. DE Results Calculated Using Standard 152 and Measured Temperatures

\begin{tabular}{|c|c|c|c|c|c|c|}
\hline $\begin{array}{l}\text { Site } \\
\text { ID }\end{array}$ & $\begin{array}{c}\text { Heating } \\
\text { Indoor } \\
\text { Temperature } \\
\left({ }^{\circ} \mathbf{F}\right)\end{array}$ & $\begin{array}{c}\text { Cooling } \\
\text { Indoor } \\
\text { Temperature } \\
\left({ }^{\circ} \mathbf{F}\right)\end{array}$ & $\begin{array}{c}\text { Heating } \\
\text { Attic } \\
\text { Temperature } \\
\left({ }^{\circ} \mathrm{F}\right)\end{array}$ & $\begin{array}{c}\text { Cooling } \\
\text { Attic } \\
\text { Temperature } \\
\left({ }^{\circ} \mathrm{F}\right)\end{array}$ & $\begin{array}{c}\text { Heating } \\
\text { DE }\end{array}$ & $\begin{array}{c}\text { Cooling } \\
\text { DE }\end{array}$ \\
\hline B-2 & & 76 & & 113 & & $87.3 \%$ \\
\hline B-4 & 70 & 76 & 41 & 103 & $92.4 \%$ & $89.7 \%$ \\
\hline B-5 & & 73 & & 102 & & $85.9 \%$ \\
\hline B-6 & & 76 & & 99.5 & & $89.7 \%$ \\
\hline B-7 & 68 & & 44.3 & & $87.5 \%$ & \\
\hline $\begin{array}{c}\text { A-1 } \\
\text { (DCS) }\end{array}$ & 70 & 78 & 54 & 99 & $99.6 \%$ & $99.4 \%$ \\
\hline $\begin{array}{c}\text { A-2 } \\
\text { (HPA) }\end{array}$ & 67 & 76 & 54 & 94 & $93.4 \%$ & $93.1 \%$ \\
\hline $\begin{array}{c}\text { A-3 } \\
\text { (NVA) }\end{array}$ & 70 & 73 & 68 & 80 & $99.4 \%$ & $99.4 \%$ \\
\hline $\begin{array}{c}\text { A-4 } \\
\text { (NVA) }\end{array}$ & 70 & 72 & 77 & 77 & $99.1 \%$ & $98.8 \%$ \\
\hline $\begin{array}{c}\text { A-5 } \\
\text { (DCS) }\end{array}$ & & 76 & & 136 & & $95.1 \%$ \\
\hline
\end{tabular}

Table 13 shows the results of the same Standard 152 calculations that used the measured DSAs, airflow rates, and duct leakage but substitute the design and seasonal attic temperatures and supply air temperatures that are listed in Standard 152 for cities that are closest to the test sites (Sacramento and Fresno). Duct leakage and airflow rates could not be measured for all sites because of access and schedule limitations, so the same sites that are omitted from Table 12 also do not appear in Table 13.

A comparison of Table 12 and Table 13 suggests that temperature assumptions used by Standard 152 yield reliable results. DEs calculated using measured conditions fell between the seasonal and design DEs that were calculated using Standard 152 assumptions for all base-case (B) sites under heating and cooling conditions. Though the "A" site results showed more variations, Standard 152 assumptions yielded DEs that were very close, and in some cases identical, to the DEs calculated using measured temperatures, airflow, and leakage.

Table 13 also compares DEs for houses with advanced distribution systems to base-case houses by aligning the number of stories and floor areas. Base cases used for individual "advanced" houses changed depending on the availability of test data in heating and cooling modes. Estimated improvements in DE are listed in the right two columns. 
Table 13. DE Results Calculated Using Standard 152 and Design and Seasonal Temperatures

\begin{tabular}{c|c|c|c|c|c|c|c|c}
\hline Advanced & \multirow{2}{*}{$\begin{array}{c}\text { Mase } \\
\text { Code }\end{array}$} & \multirow{2}{*}{$\begin{array}{c}\text { Base } \\
\text { Case }\end{array}$} & \multicolumn{2}{c|}{ Base Case DE \% } & \multicolumn{2}{c|}{ Advanced DE \% } & \multicolumn{2}{c}{ \% Improvement } \\
\cline { 5 - 9 } & Design & Seasonal & Design & Seasonal & Design & Seasonal \\
\hline $\begin{array}{c}\text { A-1 } \\
\text { (DCS) }\end{array}$ & Cool & B-4 & 85.8 & 90.2 & 99.1 & 99.4 & $16 \%$ & $10 \%$ \\
$\begin{array}{c}\text { A-1 } \\
\text { (DCS) }\end{array}$ & Heat & B-5 & 92.7 & 93.7 & 99.5 & 99.7 & $7 \%$ & $6 \%$ \\
$\begin{array}{c}\text { A-2 } \\
\text { (HPA) }\end{array}$ & Cool & B-6 & 85.3 & 90.0 & 88.6 & 92.2 & $4 \%$ & $2 \%$ \\
$\begin{array}{c}\text { A-2 } \\
\text { (HPA) }\end{array}$ & Heat & B-7 & 87.3 & 89.7 & 91.4 & 93.4 & $5 \%$ & $4 \%$ \\
$\begin{array}{c}\text { A-3 } \\
\text { (NVA) }\end{array}$ & Cool & B-2 & 86.3 & 90.3 & 98.7 & 99.1 & $14 \%$ & $10 \%$ \\
$\begin{array}{c}\text { A-4 } \\
\text { (NVA) }\end{array}$ & Cool & B-4 & 85.8 & 90.2 & 97.1 & 98.2 & $13 \%$ & $9 \%$ \\
$\begin{array}{c}\text { A-4 } \\
\text { (NVA) }\end{array}$ & Heat & B-4 & 92.7 & 93.7 & 98.6 & 98.8 & $6 \%$ & $5 \%$ \\
$\begin{array}{c}\text { A-5 } \\
\text { (DCS) }\end{array}$ & Cool & B-4 & 85.8 & 90.2 & 96.6 & 97.9 & $13 \%$ & $9 \%$ \\
\hline
\end{tabular}

The DE for Site A-1 exceeded $99 \%$ and reflects very low duct leakage. The furnace and ducts were placed fully within conditioned space (zero DLO). Site A-5 ducts are also in an enclosed, insulated duct chase; however, some leakage to the outside was measured because of incomplete sealing, and chases were not uniformly well insulated. Site A-3 and A-4 ducts were in fully conditioned attic spaces; the lower DE for Site A-4 resulted from measurable DLO. The HPA system (Site A-2) had the lowest DE of the high-performance house group because about $80 \%$ of the supply ducting is in the vented attic, but the improvement over base-case heating and cooling DEs of $5 \%$ and $4 \%$ is still significant.

\subsection{Observed Delivery Effectiveness}

ODE is another way of looking at the field data and uses measured airflow and temperature differences to calculate DE (Equation 3) instead of applying the Standard 152 methods. For example, "Btu to the register" was compared to Btu supplied into each duct run; results were summed to obtain the overall system ODE. This calculation approach treats losses to unoccupied space as thermal losses, because some of the energy that leaves the furnace does not arrive at the supply register and is lost to the attic (or buffer) space, even if it is still within the thermal enclosure. The Standard 152 calculations can account for "regain," or energy lost from DCS (such as crawlspaces) that reduces building load by creating lower temperature differences. However, Standard 152 treats NVAs as conditioned space; therefore, it is not subject to regain.

Figure 15 allows the ODE measurements to be compared to the Standard 152 DE calculations (applying site-measured temperatures, flow rates, and duct leakage). The observed heating (red horizontal bar) and cooling (blue horizontal bar) DE values are plotted for each site. The shaded red and blue bars represent the range of measurement accuracy. The uncertainty is $\pm 7 \%$, and in most sites the Standard 152 calculated DE falls within the error of the observed measurement. 


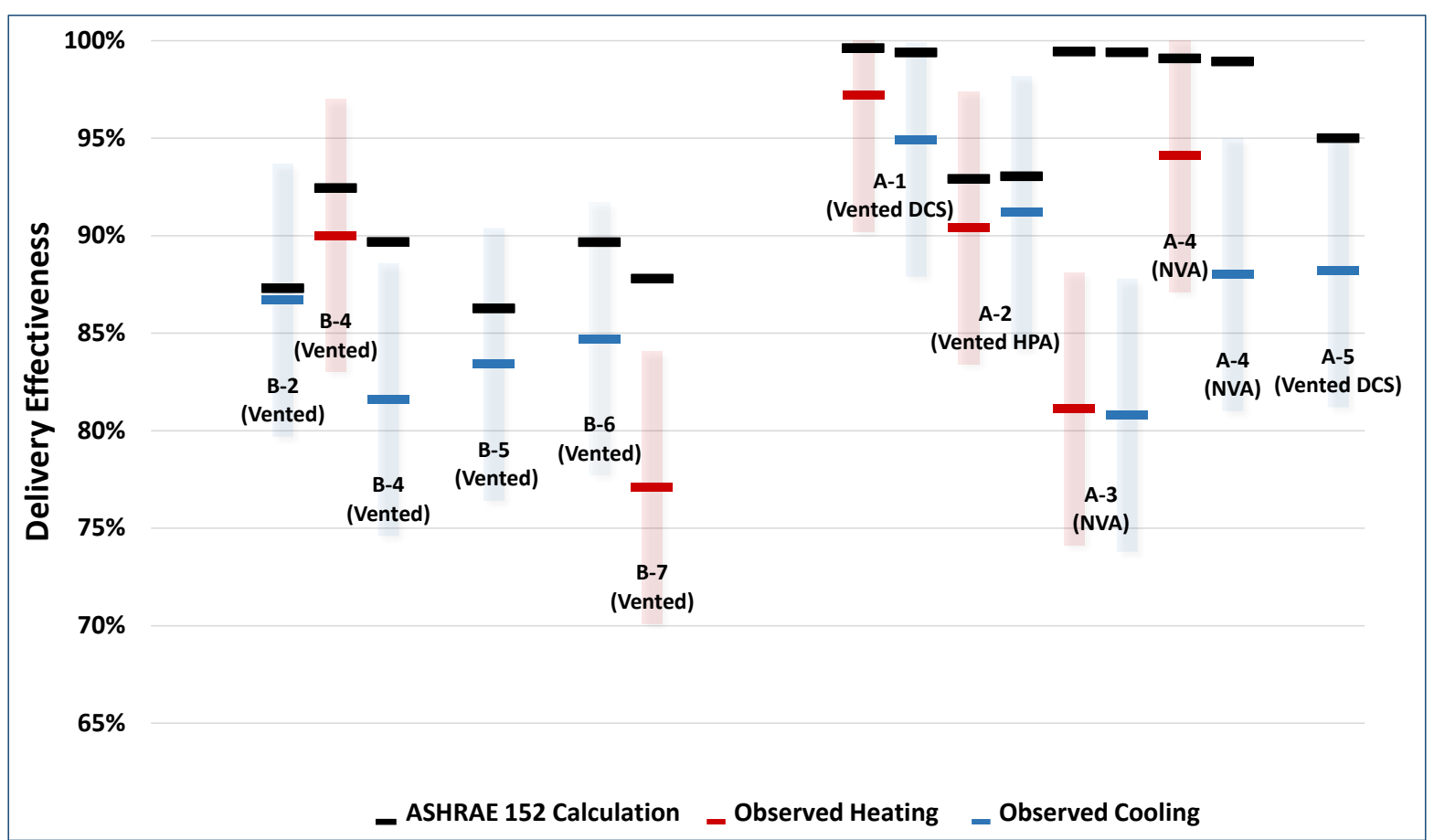

Figure 15. Comparison of heating and cooling ODEs versus Standard 152 single-point DEs

For the NVA sites (A-3 and A-4) the differences between ODE (about 81\%) and DE (about 99\%) are very large and suggest significant losses to the attic space. Determining the magnitude of the regain effect relative to added attic air leakage and conduction losses will require more research.

The ODEs for base-case site B-4 in the cooling season and B7 in the heating season were much lower than the Standard 152 calculation shows. In other words, the observed losses at these sites were higher than estimated using the Standard 152 calculation. Similar differences are seen for the NVA sites (A3 and A4). This may be explained by measurement and calculation uncertainties, large DSAs in attic spaces, higher or lower attic temperatures, and lower system fan airflow rates. Calculated DEs are consistently higher than measured ODEs and are similar at only one site (B-2). This discrepancy suggests other factors are at play that Standard 152 does not capture. 


\section{Modeling Results}

\subsection{Base Case}

This modeling exercise compared heating, cooling, and source energy tradeoffs for each HPD strategy and generated energy savings data that can be used to estimate cost-effectiveness. Table 14 presents HVAC source energy results from BEopt modeling for the Benchmark case and a revised base case, which includes all Benchmark properties, except that $6 \%$ duct leakage was applied instead of $15 \%$. On average the percentage savings impact of tightening ducts from $15 \%$ to $6 \%$ on the benchmark house was fairly constant across all climates and yielded about $7 \%$ savings for the $2,100-\mathrm{ft}^{2}$ prototype and $5 \%$ for the $2,700-\mathrm{ft}^{2}$ prototype.

Table 14. Base-Case BEopt Modeling Results

\begin{tabular}{|c|c|c|c|c|c|c|c|c|c|}
\hline \multirow[t]{2}{*}{ Case } & \multirow[t]{2}{*}{ End Use } & \multicolumn{4}{|c|}{$\begin{array}{c}\text { Source HVAC Energy Use } \\
\text { (MMBtu/yr) } \\
\text { 2,100-ft }{ }^{2} \text { Prototype } \\
\end{array}$} & \multicolumn{4}{|c|}{$\begin{array}{c}\text { Source HVAC Energy Use } \\
\text { (MMBtu/yr) } \\
\text { 2,700-ft }{ }^{2} \text { Prototype } \\
\end{array}$} \\
\hline & & Phoenix & Fresno & Sac & Albq & Phoenix & Fresno & Sac & Albq \\
\hline \multirow{4}{*}{ 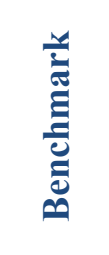 } & HVAC Fan & 13.29 & 7.29 & 4.68 & 7.32 & 16.9 & 9.85 & 6.52 & 10.13 \\
\hline & Cooling & 52.42 & 19.75 & 7.83 & 8.61 & 65.52 & 26.12 & 11.22 & 12.68 \\
\hline & Heating & 5.48 & 26.61 & 33.81 & 52.02 & 10.49 & 37.24 & 45.57 & 68.9 \\
\hline & Total & 71.19 & 53.65 & 46.32 & 67.95 & 92.91 & 73.21 & 63.31 & 91.71 \\
\hline \multirow{4}{*}{ 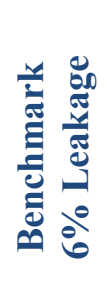 } & HVAC Fan & 12.26 & 6.78 & 4.39 & 6.90 & 15.87 & 9.33 & 6.22 & 9.7 \\
\hline & Cooling & 48.33 & 18.27 & 7.26 & 7.95 & 61.46 & 24.58 & 10.57 & 11.93 \\
\hline & Heating & 5.12 & 24.92 & 31.67 & 48.70 & 9.97 & 35.47 & 43.42 & 65.58 \\
\hline & Total & 65.71 & 49.97 & 43.32 & 63.55 & 87.3 & 69.38 & 60.21 & 87.21 \\
\hline
\end{tabular}

\subsection{Projected Energy Savings and Distribution Effectiveness}

Table 15 and Table 16 show predicted source energy savings for the one-story and two-story prototypes, respectively, and percentage savings relative to DCS (as the standard). For example, in the one-story house in Phoenix, energy savings with the HPA case (5.7 MBtu) represent $69 \%$ of the savings achieved with DCS $(8.8 \mathrm{MBtu})$. Energy savings are relative to the Benchmark house with $6 \%$ duct leakage rather than the Benchmark's $15 \%$ to demonstrate the impacts of the various strategies beyond the duct sealing measure.

DCS and DBDs yield the highest HVAC source energy savings, which amount to about $12 \%$ for the one-story prototype and $8 \%$ for the two-story prototype. Again, these show little sensitivity to climate. Surprisingly, the DBD case outperforms the DCS case in the one-story house for all climates except Phoenix. The reduced envelope loads from the R-60 attic insulation versus R-30 used in the Benchmark is likely responsible for this outcome. The NVA is projected to achieve about $50 \%$ of the savings compared to the DCS case in the one-story home and about $75 \%$ in the two-story home ${ }^{18}$ In both prototypes the HPA achieves $50 \%-65 \%$ of the projected DCS savings,

\footnotetext{
${ }^{18}$ NVA results presented later will address total savings in more detail to better reflect actual field measured envelope leakage included in Appendix C.
} 
except for the Albuquerque location. For the one-story prototype, HPA savings exceed those for NVA in the hotter Phoenix and Fresno climates.

Table 15. 2,100- $\mathrm{ft}^{2}$ One-Story Prototype Source Energy Savings Results

\begin{tabular}{c|c|c|c|c|c|c|c|c}
\hline \multirow{2}{*}{ Strategy } & \multicolumn{3}{|c|}{ Source Energy Savings (MMBtu/yr) } & \multicolumn{4}{c}{ \% of DCS Source Savings } \\
\cline { 2 - 9 } & Phoenix & Fresno & Sac & Albq & Phoenix & Fresno & Sac & Albq \\
\hline DCS & 8.84 & 5.97 & 4.77 & 7.98 & - & - & - & - \\
HPA & 5.72 & 3.68 & 2.57 & 2.26 & $65 \%$ & $62 \%$ & $54 \%$ & $28 \%$ \\
DBD & 7.86 & 6.80 & 6.10 & 8.14 & $89 \%$ & $114 \%$ & $128 \%$ & $102 \%$ \\
NVA & 4.35 & 2.77 & 3.08 & 4.34 & $49 \%$ & $46 \%$ & $65 \%$ & $54 \%$ \\
\hline
\end{tabular}

Table 16. 2,700-ft ${ }^{2}$ two-story Prototype Source Energy Savings Results

\begin{tabular}{c|c|c|c|c|c|c|c|c}
\hline \multirow{2}{*}{ Strategy } & \multicolumn{3}{|c|}{ Source Energy Savings (MMBtu/yr) } & \multicolumn{4}{c}{ \% of DCS Source Savings } \\
\cline { 2 - 9 } & Phoenix & Fresno & Sac & Albq & Phoenix & Fresno & Sac & Albq \\
\hline DCS & 8.13 & 5.58 & 4.47 & 7.35 & - & - & - & - \\
HPA & 4.93 & 3.18 & 2.23 & 2.30 & $61 \%$ & $57 \%$ & $50 \%$ & $31 \%$ \\
DBD & 5.85 & 4.96 & 4.43 & 6.07 & $72 \%$ & $89 \%$ & $99 \%$ & $83 \%$ \\
NVA & 5.97 & 4.12 & 3.86 & 5.66 & $73 \%$ & $74 \%$ & $86 \%$ & $77 \%$ \\
\hline
\end{tabular}

The following graphs focus more narrowly on results for Phoenix and Albuquerque, which represent the hottest and coldest climates, respectively, of the four evaluated. (Additional tabular and graphical results for all the climates are presented in Appendix E.) Figure 16 and Figure 17 show projected HVAC source energy use broken down by end use for the one-story 2,100- $\mathrm{ft}^{2}$ prototype; Figure 18 and Figure 19 show energy delivery and DSE, also for the one-story prototype. HVAC source energy savings across the two climates are fairly similar for all strategies except HPA, which is a respectable 9\% in Phoenix's hot climate but drops to $4 \%$ in the colder Albuquerque climate.

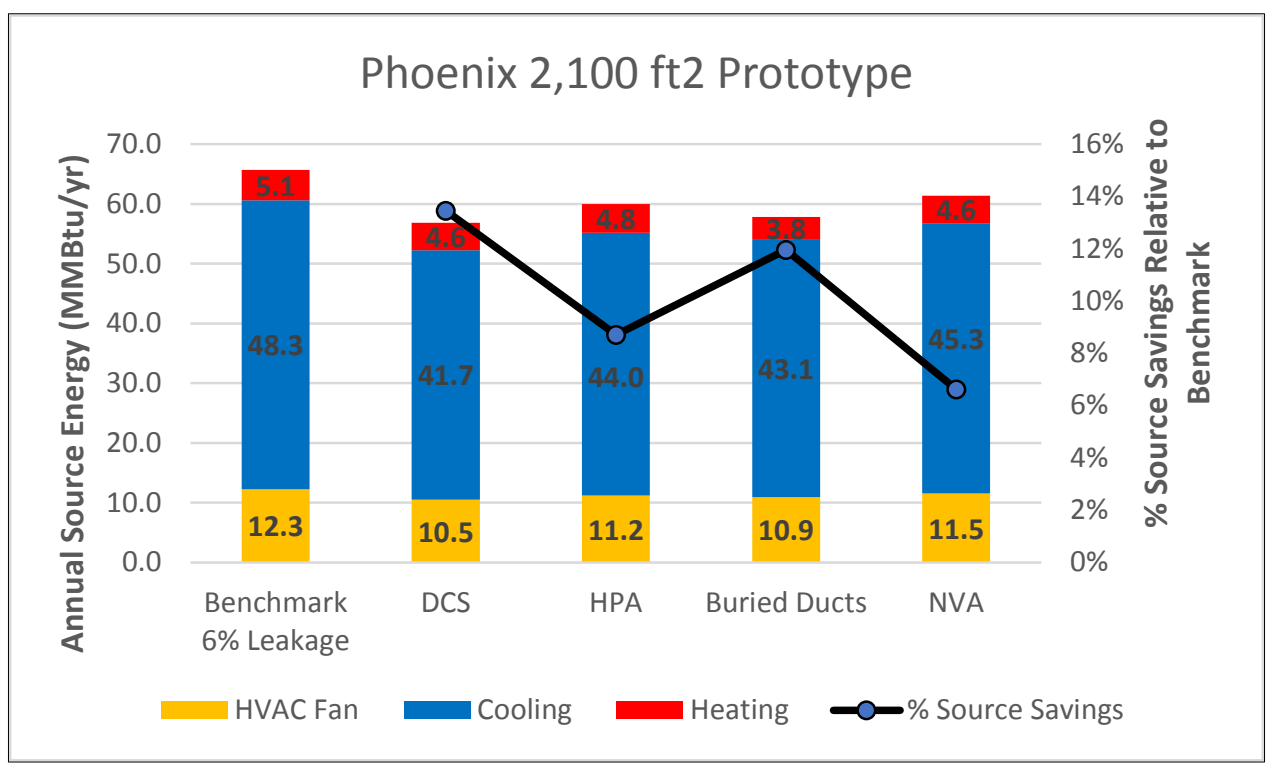

Figure 16. Phoenix annual HVAC source energy comparison $\left(2,100-\mathrm{ft}^{2}\right.$ prototype) 


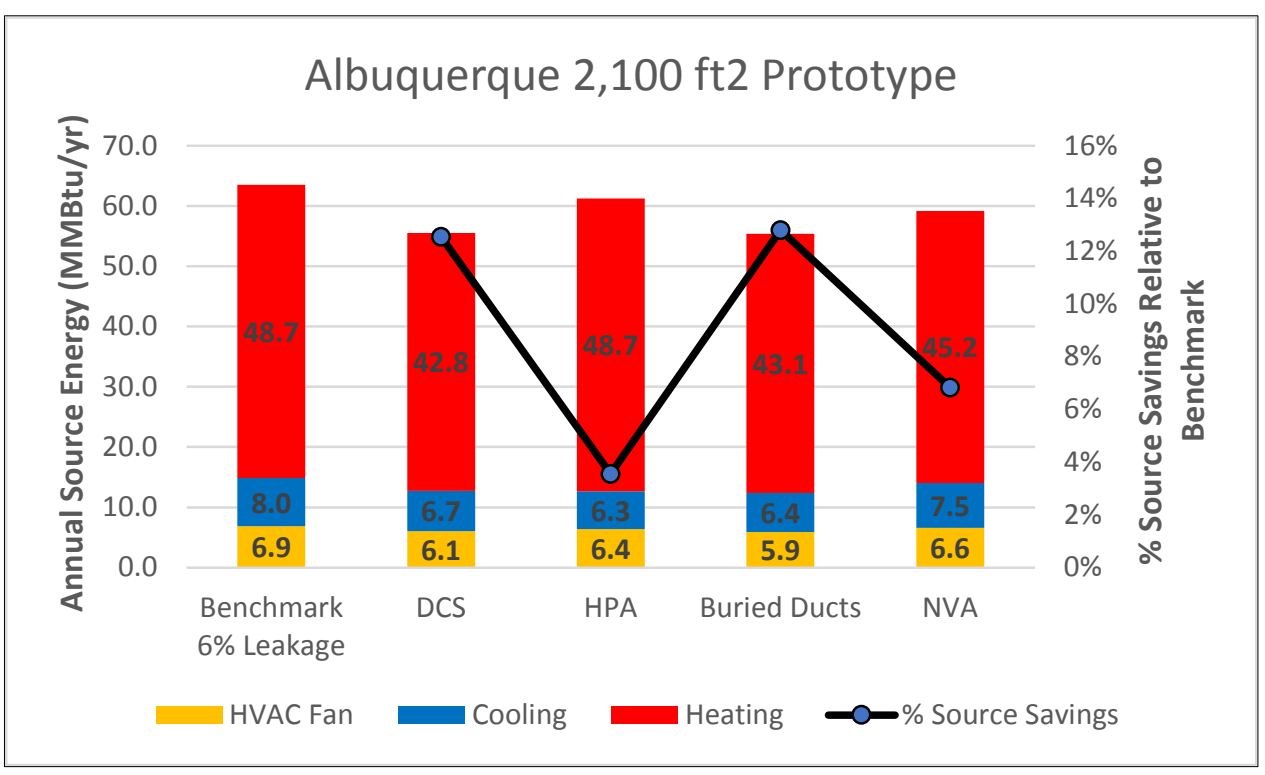

Figure 17. Albuquerque annual HVAC source energy comparison (2,100- $\mathrm{ft}^{2}$ prototype)

For Albuquerque the model results indicate that adding roof-level insulation reduces beneficial solar gains to the attic during the winter and therefore results in colder attics and increased winter duct heat losses. Seasonal DSE is only marginally improved $(1 \%-5 \%)$ beyond the base case in all the cases except DCS.

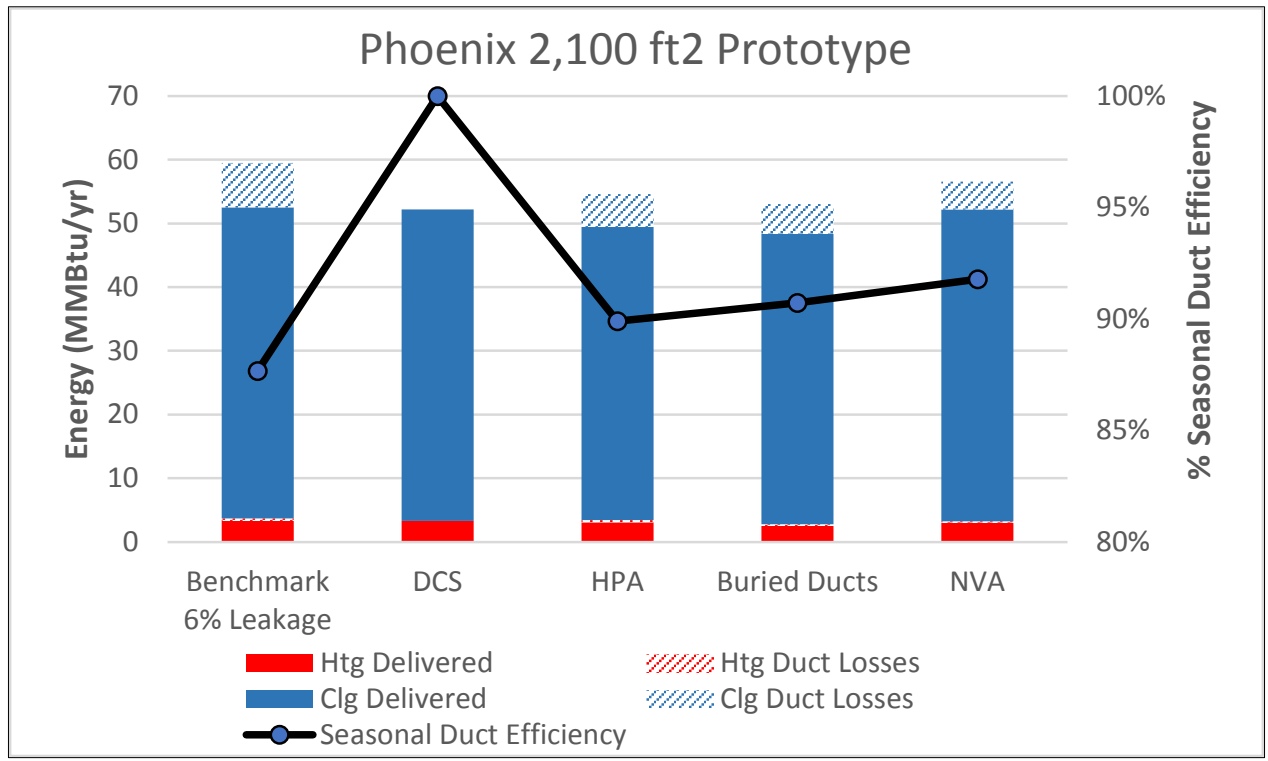

Figure 18. Phoenix DSE comparison $\left(2,100-\mathrm{ft}^{2}\right.$ prototype) 


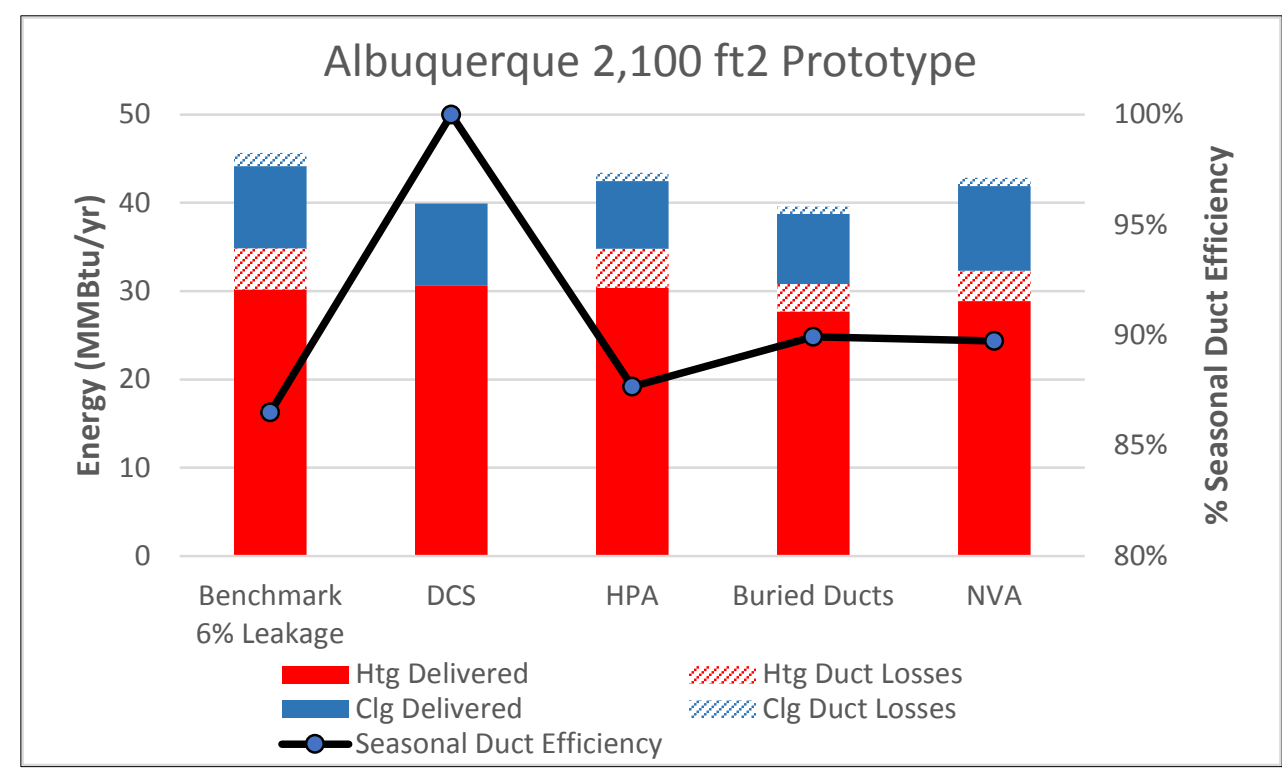

Figure 19. Albuquerque DSE comparison $\left(2,100-\mathrm{ft}^{2}\right.$ prototype)

Figure 20 through Figure 23 present additional results in the same format for the two-story $2,700-\mathrm{ft}^{2}$ prototype. The percentage savings average about $30 \%$ lower than the one-story prototype $30 \%$ because $35 \%$ of the ductwork for the two-story houses is in conditioned space. ${ }^{19}$ Also, the envelope load reduction that was caused by the increased ceiling insulation in the DBD case and increased roof insulation in the HPA case is diminished because the attic is a smaller contributor to total envelope loads on a percentage basis.

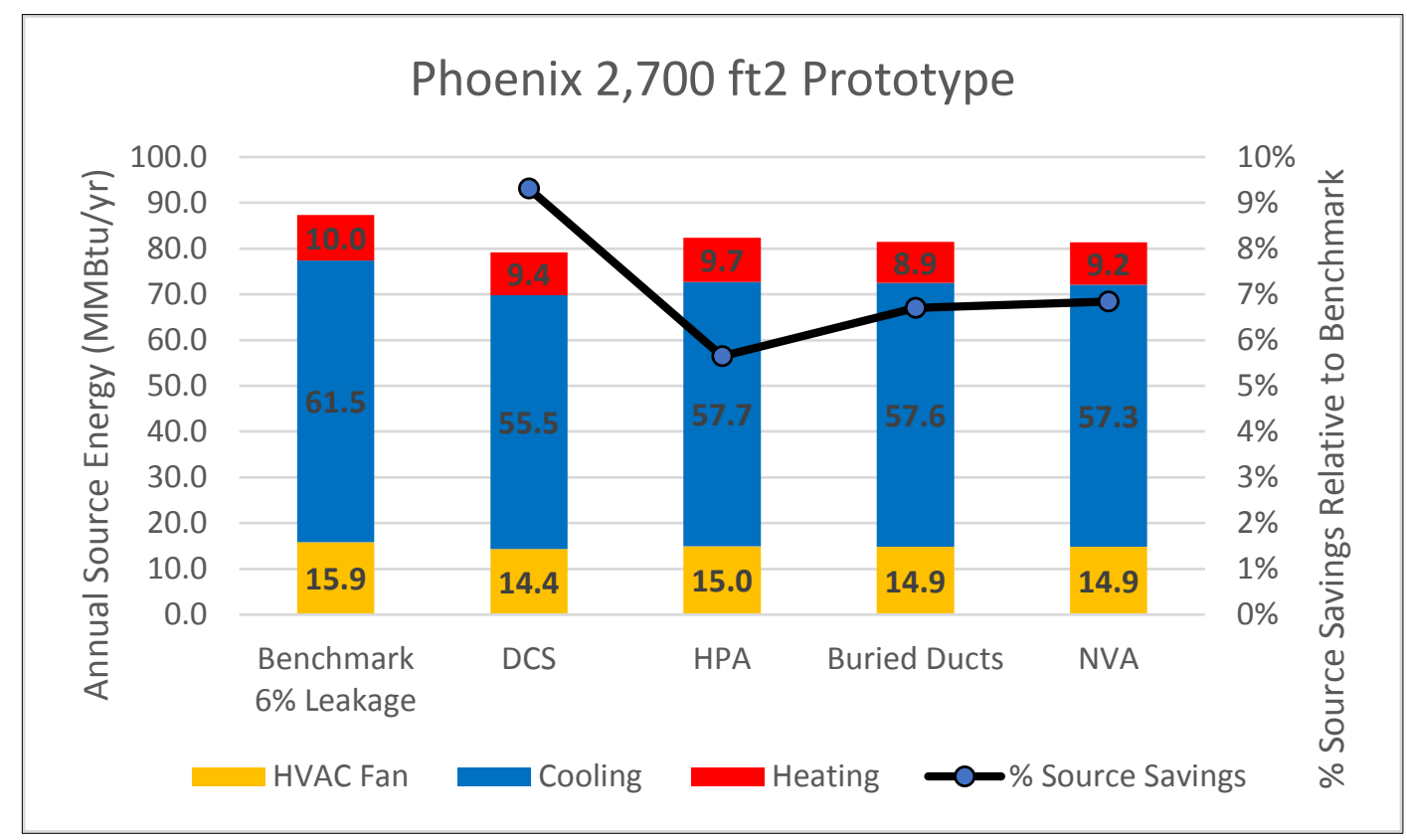

Figure 20. Phoenix annual HVAC source energy comparison $\left(2,700-\mathrm{ft}^{2}\right.$ prototype)

\footnotetext{
${ }^{19}$ Actual duct system configuration and size may affect savings differently, because BEopt assumes that $35 \%$ of the ducts are in conditioned space for two-story houses.
} 


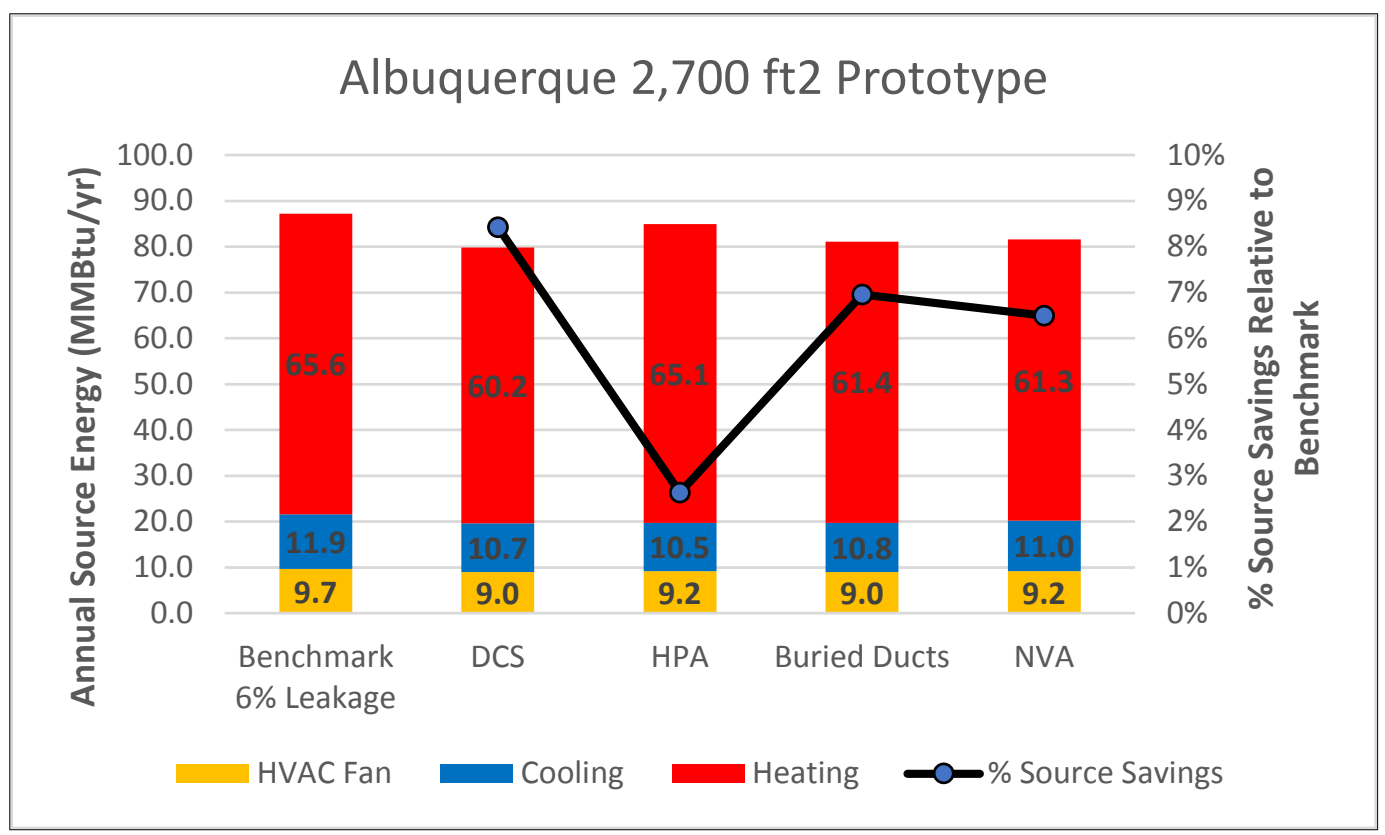

Figure 21. Albuquerque annual HVAC source energy comparison (2,700- $\mathrm{ft}^{2}$ prototype) 


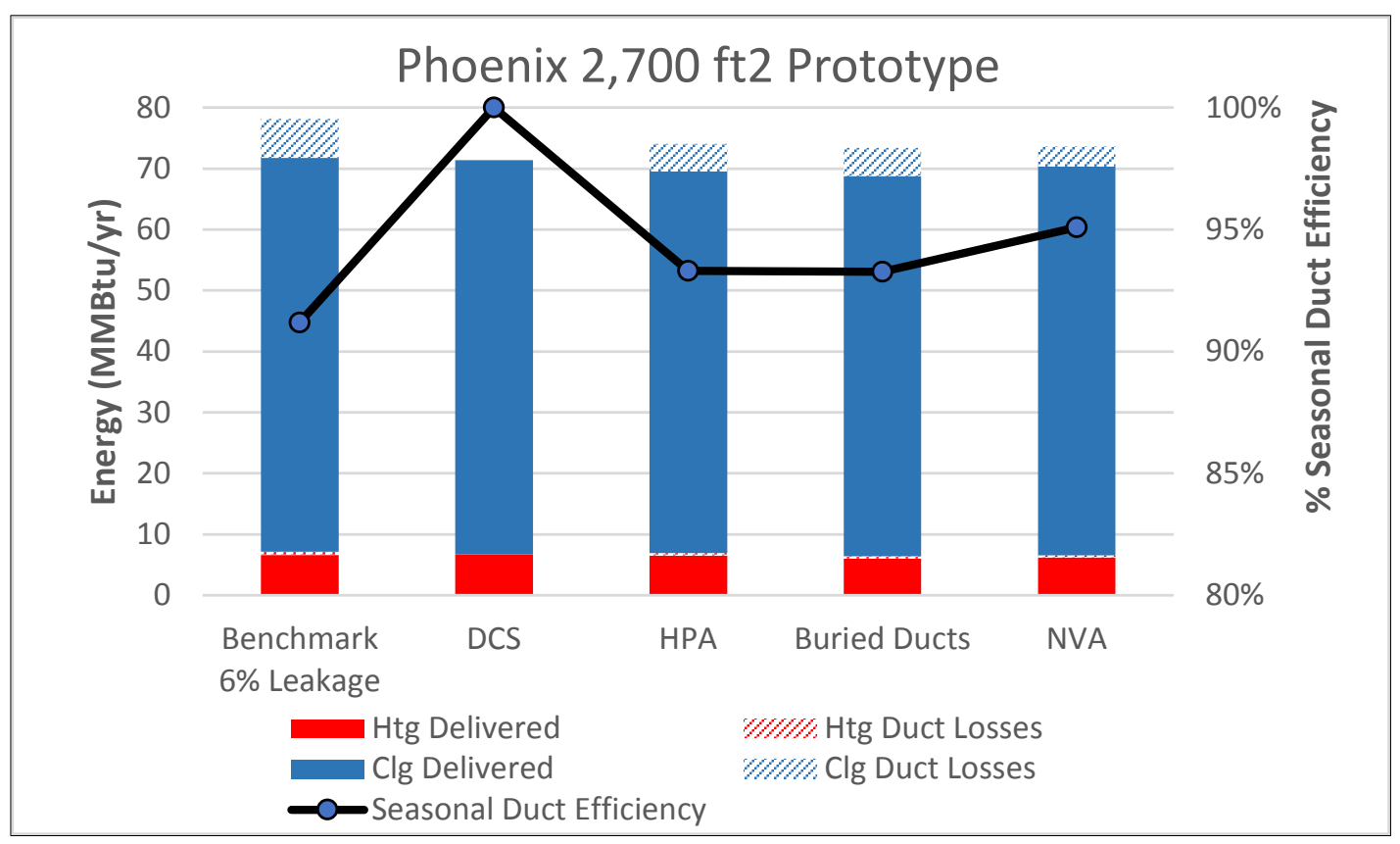

Figure 22. Phoenix DSE comparison (2,700- $\mathrm{ft}^{2}$ prototype)

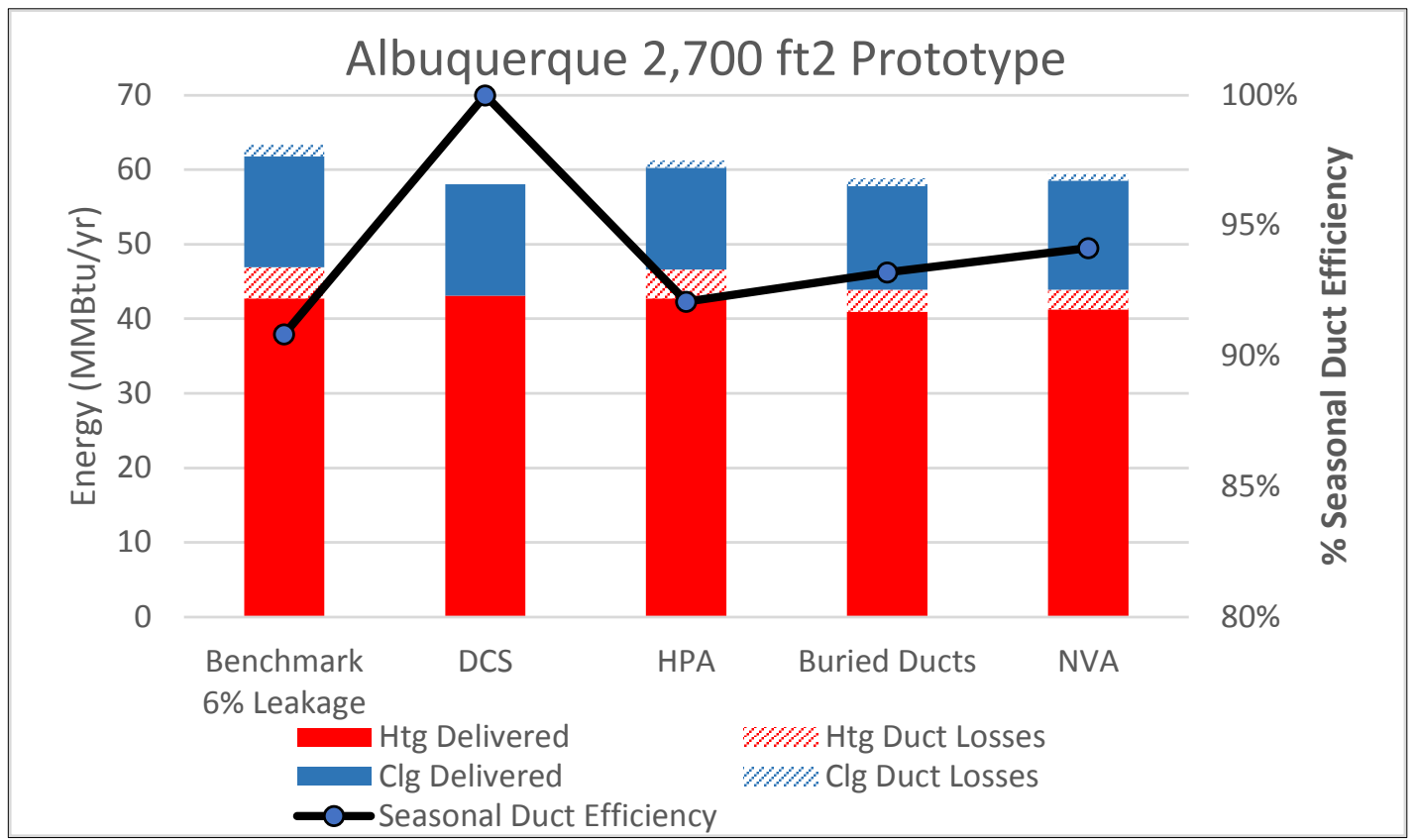

Figure 23. Albuquerque DSE comparison $\left(2,700-\mathrm{ft}^{2}\right.$ prototype)

\subsection{Additional Parametric Analysis Results}

Results presented in this section show the sensitivity of HVAC energy use to changes in infiltration rates, roof types (hip or gable), duct leakage, and DSA (to assess the value of compact duct design). These BEopt parametrics were all completed using Fresno climate data and the one-story prototype. The Fresno climate was selected for this analysis because it has 
fairly equivalent heating and cooling loads and provides a good representation of how these factors impact performance in both seasons.

\subsubsection{Nonvented Attics}

The one builder who implemented NVAs for this project uses ocSPF insulation under the roof deck and in all exterior walls. Spray foam applied to exterior walls substantially reduced building infiltration as evidenced by the 20 home sample results presented in Appendix C (testing showed that the below ceiling plane envelope leakage averaged $1.28 \mathrm{ACH} 50)$. Figure 24 demonstrates the additional savings estimated by BEopt for the reduction from the Benchmark infiltration of 7 $\mathrm{ACH} 50$ to $1.3 \mathrm{ACH} 50$. In this example, reduced leakage from the occupied part of the house significantly increased source energy savings from $6 \%$ (at 7 ACH50) to 10\%. In other climates savings increased by 2-6 percentage points for the one-story prototype and 6-12 percentage points for the two-story prototype.

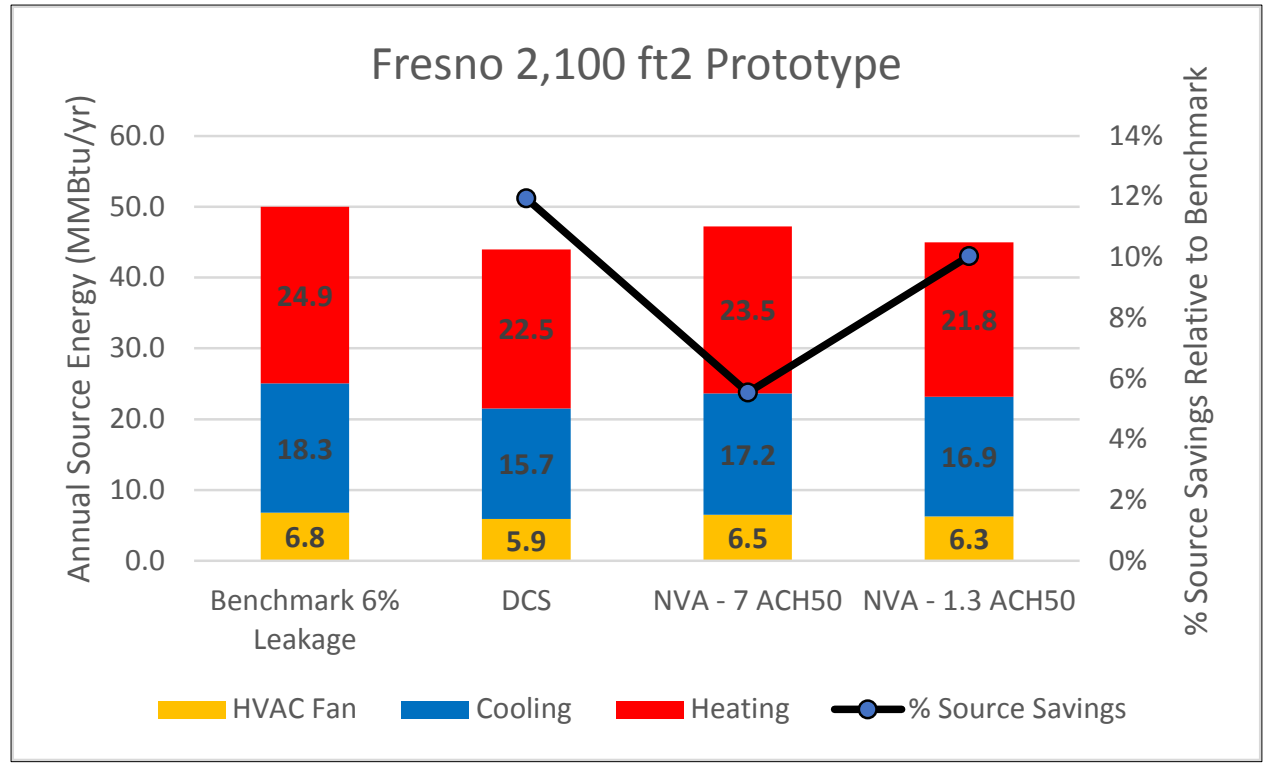

Figure 24. NVA comparison with various house infiltration values

Roof type also had a significant impact on NVA performance. Most new homes Meritage builds in California have hip roofs, which means R-30 insulation is applied to all exterior surfaces in the attic. ${ }^{20}$ However, gable walls are insulated to the same level as other exteriors walls, which would be lower than R-30. Figure 25 shows the results of this analysis using a Benchmark wall ( $2 \times 4$ with R-13 insulation). Results indicate increased energy use for the Benchmark and NVA cases when the roof type is changed from hip to gable. Higher R-value attic walls ${ }^{21}$ would show a lesser impact.

\footnotetext{
${ }^{20}$ Meritage currently uses R-20 foam but will have to increase the R-value to 30 to stay in compliance with 2013 Title 24 and the 2010 International Energy Conservation Code.

${ }^{21}$ R-15 walls with R-4 exterior insulation are common in northern and central California.
} 


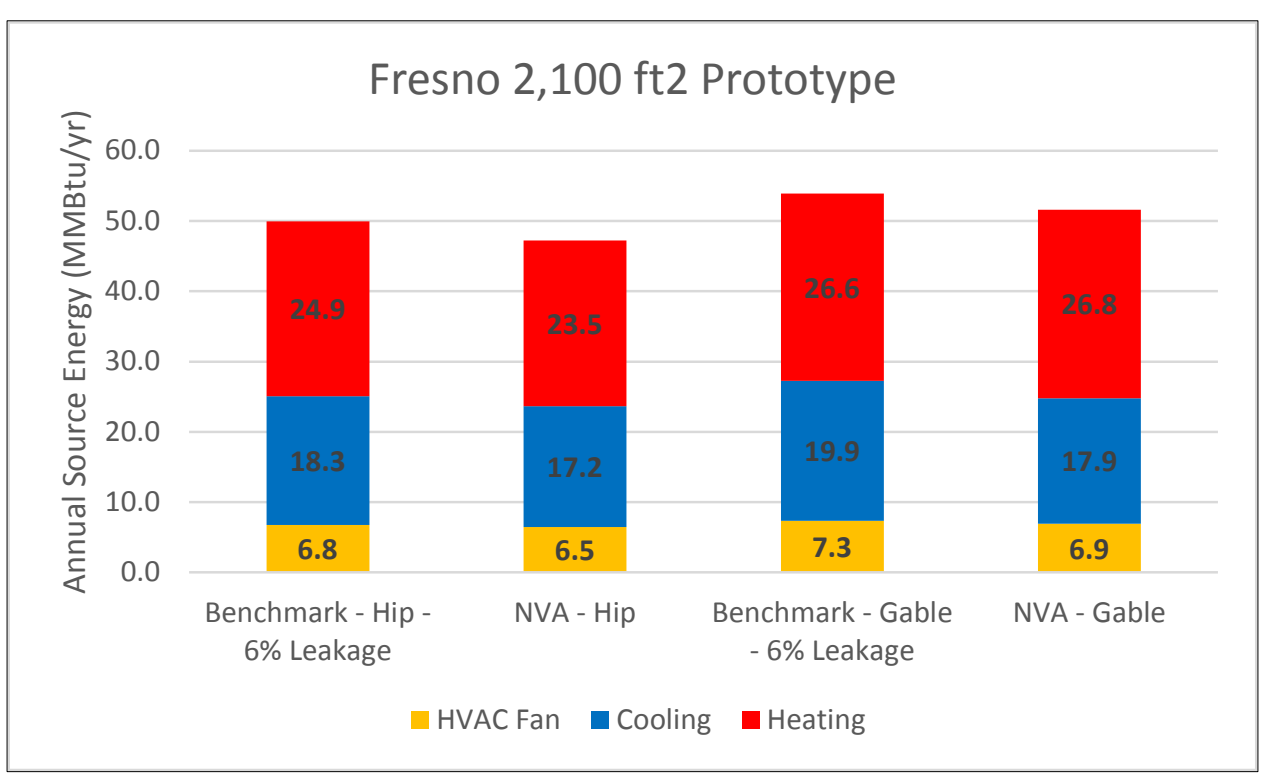

Figure 25. NVA comparison of hip versus gable roofs

\subsubsection{Duct Leakage}

All the previous results have been compared to a Benchmark house with $6 \%$ duct leakage. Figure 26 demonstrates the impact of decreasing duct leakage from the $15 \%$ Benchmark value to $6 \%$, resulting in a $6.4 \%$ impact on source energy savings. For the DCS case, also graphed for comparison, the model does not account for any duct leakage or thermal losses to the outside.

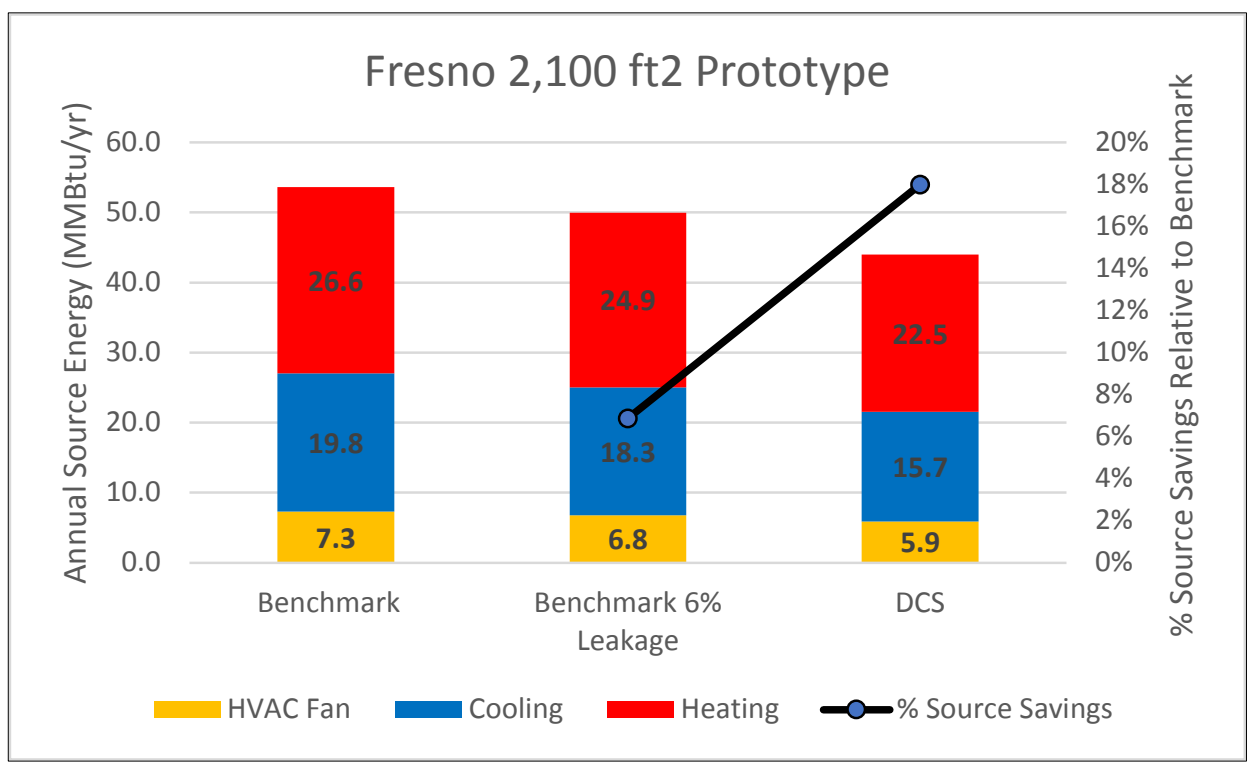

Figure 26. Impact of reducing duct leakage from $15 \%$ to $6 \%$ for typical attic duct systems

Minimizing duct leakage is an important component of all measures to improve DE, even for DCS. However, BEopt does not account for the thermal impact of air distribution to spaces that are physically separated from occupied conditioned space such as duct chases and NVAs. Leakage to chases that are not perfectly sealed will still result in leakage to the exterior of the 
home. As demonstrated by the field tests, leakage to unoccupied spaces can significantly reduce Btu delivered to the register.

\subsubsection{Compact Duct Design}

Compact duct designs that result in shorter duct runs and lower DSA were also evaluated. Figure 27 shows the HVAC source energy savings that BEopt predicted for the standard duct design with surface areas as documented in Table 9. Figure 28 shows the same analysis except that the supply DSA was reduced by $40 \%$ for all the advanced distribution cases. The predicted source energy improvement is roughly 1-2 percentage points. However, BEopt also does not account for the effects of duct pressure drop on system fan and compressor energy use. Compact duct design can also reduce construction costs, particularly when ducts are in dropped-ceiling or attic chases, which are expensive to construct, air seal, and insulate.

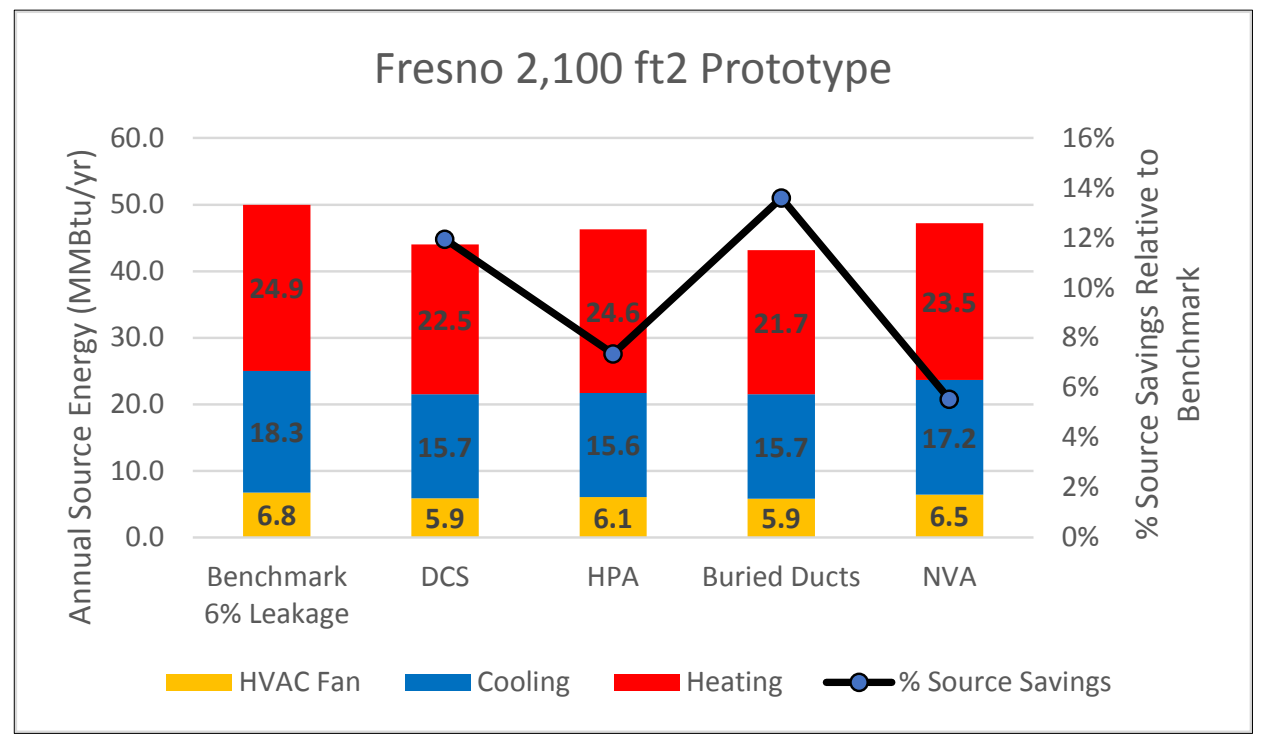

Figure 27. Source energy use comparison for typical duct designs (Benchmark assumptions)

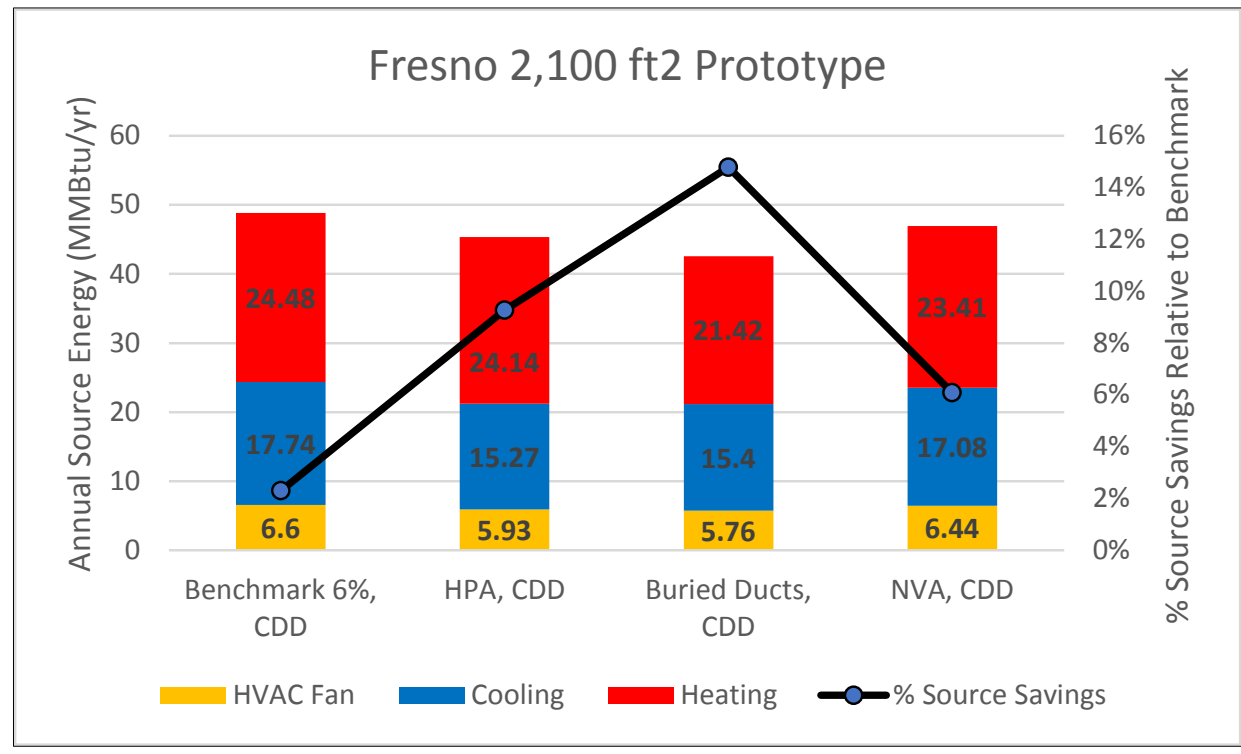

Figure 28. Source energy use for compact duct designs 


\section{High-Performance Duct System Costs and Cost-Effectiveness}

\subsection{The Mature Market Cost Dilemma}

Developing representative costs for the various HPD strategies is challenging, as evidenced by the builders' experiences with implementing them. Mature costs cannot be fully verified until (1) these strategies become standard practice and are integrated into builders' routine design and procurement processes, and (2) HVAC contractors embrace the strategies and become accustomed to applying these practices.

\subsection{Cost Information Sources}

To develop cost assumptions for this study the authors relied largely on experiences, conditions encountered, and observations made through the fieldwork completed for this project. CEC (2015) also provided some information. Regional variations in residential design, construction practices, labor costs, and other factors may affect costs in other states.

Builders that participated in this project helped identify cost savings associated with downsizing HVAC equipment that came about because duct losses (and thus loads) were reduced. Three of the four builders provided cost savings for reducing condensing unit size. ${ }^{22}$ The cost reduction averaged $\$ 227$ per half ton $(\$ 180, \$ 200$, and $\$ 300)$. Integrating other measures that could achieve a ZERH rating would result in greater size reductions as well as furnace downsizing and duct material cost savings.

Builders also provided assistance in developing costs for constructing enclosed duct chases. In particular, one builder that implemented attic duct chases provided very detailed cost data that were used as the foundation for developing the costs for DCS. Because these costs were based on subdivision-wide implementation of this approach on more than 150 homes, they represented the only PG\&E project data point where the costing was not based on a one-off construction cost estimate.

For the G.J. Gardner 1,816- $\mathrm{ft}^{2}$ one-story floor plan shown in Figure 8, the installed $100 \mathrm{ft}$ of 24 -in. wide and 28 -in. tall duct chase was reported to cost an extra $\$ 2,967$ to build, air seal, ${ }^{23}$ and insulate. The installed $666 \mathrm{ft}^{2}$ of duct chase surface area resulted in a cost of $\$ 4.45 / \mathrm{ft}^{2}$ to construct a completed attic duct chase. Insulation (R-19 on chase knee walls and batts totaling R-49 on chase top surface) is estimated to cost $\$ 0.90 / \mathrm{ft}^{2}$; chase air sealing was estimated at $\$ 0.52 / \mathrm{ft}^{2}$.

Except for HPA and DBD, all advanced distribution strategies require that mechanical equipment be placed in conditioned space. In such cases a sealed combustion furnace (or heat pump) is required, which adds cost but also increases heating efficiencies. CEC (2015) identified incremental costs for sealed combustion furnaces of $\$ 110-\$ 360$ compared to a standard $80 \%$ annual fuel utilization efficiency furnace, depending upon equipment capacity and efficiency. A major northern California HVAC contractor suggested an incremental cost of about $\$ 400$. For California applications where builders are exceeding Title 24 standards by $20 \%$ or more,

\footnotetext{
${ }^{22}$ The fourth builder indicated that its HVAC contractor would not provide this type of cost information because it was considered sensitive.

${ }^{23}$ The builder used the EcoSeal product to attempt to seal the attic duct chases. EcoSeal is an elastomeric product that is spray applied. For more information see http://www.knaufinsulation.us/content/knauf-insulation-ecosealsealant.
} 
condensing furnaces are common. ${ }^{24}$ This suggests the average California cost increment for sealed combustion furnaces may be minimal.

\subsection{Development of Costs}

\subsubsection{Measures Included}

Individual cost estimates were prepared for each advanced distribution measure investigated, including DCS (attic chases and dropped-ceiling methods), NVA, DBDs (R-60 attic insulation and effective duct R-value of 20), and HPA. The specifications that were used for costing HPA are similar to those adopted by the CEC (2015), and include R-30 insulation at the ceiling, R-13 installed under the roof deck with a tile roof above, 5\% duct leakage, and R-8 duct insulation.

\subsubsection{Ducts in Conditioned Space Cost Details}

Costs from the $1,816-\mathrm{ft}^{2}$ plan were applied to the $2,100-\mathrm{ft}^{2}$ one-story and 2,700- $\mathrm{ft}^{2}$ two-story prototypes used for BEopt modeling (Table 17). The 2,100- $\mathrm{ft}^{2}$ "Attic Chase-Standard" costing in the table is for the standard design and implementation approach used by the three DCS builders. Table 17 also lists costs for a compact duct design as represented in Figure 7 . For the compact duct design the length of the ducting and chases is assumed to be reduced by $50 \%$ and the height of the chase is reduced from the $28 \mathrm{in}$. used by the builders to a more appropriate 12 in. The impact on costs is significant; the incremental cost is reduced from $\$ 3,129$ to $\$ 1,003$. The "other costs" shown in the table include:

- Added cost for an indoor mechanical closet (estimated at \$267 based on builder information provided)

- An additional \$125 for HERS testing for DLO (CEC 2015)

- A $\$ 227$ credit for downsizing the air conditioner by 0.5 ton

- A small reduction in duct material costs for compact distribution systems.

When asked the value of floor space that is given up for a mechanical closet on the first or second floor, one builder estimated it at $\$ 1,500$, or nearly $\$ 100 / \mathrm{ft}^{2}$. This cost could vary substantially from builder to builder and introduces some uncertainty to the DCS costs listed in Table 17. Table 17 also includes cost estimates for two dropped-ceiling DCS approaches, one for a standard duct design and one for a compact design. Although this strategy met with significant resistance from the participating builders (primarily because of ceiling height concerns), it offers significant cost advantages by eliminating the need for attic knee wall insulation and air sealing. From that perspective, the authors feel that as DCS strategies become more mature and accepted by the construction industry, builders that pursue DCS strategies will tend to move toward the dropped-ceiling approach.

Costs for the dropped-ceiling designs borrow from the compact and as-built duct layouts that were proposed for G.J. Gardner's 1,816- $\mathrm{ft}^{2}$ plan (see Figure 7 and Figure 8) but applied to the 2,100- and 2,700- $\mathrm{ft}^{2}$ prototypes. The hallway ceilings are dropped 12-in. from either a 9-ft or 10$\mathrm{ft}$ plate line. Costs for the attic chase are presented for both a standard installation that represents current practice and an improved compact design. These DCS strategies are dependent on the layout of the floor plan; cost and implementation issues will vary. When HPD strategies reach

\footnotetext{
${ }^{24}$ Personal communication with CAHP manager Matt Christie (January 9, 2015) and a Title 24 compliance consultant.
} 
maturity with production builders, compact duct distribution design and efficient air delivery requirements must be assumed to be factored into the architectural design process to the extent traffic flow, aesthetics, and market appeal are currently considered.

Table 17. Estimated Costs for Attic Chase and Drop Ceiling DCS Configurations

\begin{tabular}{|c|c|c|c|c|c|c|}
\hline Description & $\begin{array}{c}\text { Estimated } \\
\text { Chase Length } \\
\text { (ft) }\end{array}$ & $\begin{array}{c}\text { Chase } \\
\text { Surface Area } \\
\left(\mathrm{ft}^{2}\right)\end{array}$ & $\begin{array}{c}\text { Cost of } \\
\text { Chase Area } \\
\left(\text { per } \mathbf{f t}^{2}\right)\end{array}$ & $\begin{array}{c}\text { Total } \\
\text { Chase } \\
\text { Cost }\end{array}$ & $\begin{array}{l}\text { Other } \\
\text { Costs }\end{array}$ & $\begin{array}{l}\text { Total } \\
\text { Cost }\end{array}$ \\
\hline \multicolumn{7}{|c|}{$2,100-\mathrm{ft}^{2}$ One-Story Prototype } \\
\hline $\begin{array}{l}\text { Attic Chase- } \\
\text { Standard }\end{array}$ & 100 & 666 & $\$ 4.45$ & $\$ 2,964$ & $\$ 165$ & $\$ 3,129$ \\
\hline $\begin{array}{c}\text { Attic Chase- } \\
\text { Compact }\end{array}$ & 50 & 214 & $\$ 4.45$ & $\$ 953$ & $\$ 50$ & $\$ 1,003$ \\
\hline $\begin{array}{l}\text { Drop Ceiling- } \\
\text { Standard }\end{array}$ & 80 & 228 & $\$ 3.03$ & $\$ 692$ & $\$ 119$ & $\$ 811$ \\
\hline $\begin{array}{l}\text { Drop Ceiling- } \\
\text { Compact }\end{array}$ & 40 & 114 & $\$ 3.03$ & $\$ 346$ & $\$ 27$ & $\$ 373$ \\
\hline \multicolumn{7}{|c|}{ 2,700- $\mathrm{ft}^{2}$ One-Story Prototype } \\
\hline $\begin{array}{c}\text { Attic Chase- } \\
\text { Standard }\end{array}$ & 75 & 500 & $\$ 4.45$ & $\$ 2,223$ & $\$ 165$ & $\$ 2,388$ \\
\hline $\begin{array}{l}\text { Attic Chase- } \\
\text { Compact }\end{array}$ & 37.5 & 161 & $\$ 4.45$ & $\$ 714$ & $\$ 50$ & $\$ 764$ \\
\hline $\begin{array}{l}\text { Drop Ceiling- } \\
\text { Standard }\end{array}$ & 60 & 171 & $\$ 3.03$ & $\$ 519$ & $\$ 119$ & $\$ 638$ \\
\hline $\begin{array}{l}\text { Drop Ceiling- } \\
\text { Compact }\end{array}$ & 30 & 86 & $\$ 3.03$ & $\$ 259$ & $\$ 27$ & $\$ 286$ \\
\hline
\end{tabular}

\subsubsection{Nonvented Attic Cost Details}

NVA costs were built up based on cost information provided by Meritage for the two test houses it contributed for the PG\&E project. Table 18 summarizes the incremental costs based on the attic roof deck areas and Meritage's reported costs for R-20 to R-22 roof deck insulation. A cost increment was added to bring the roof deck insulation to R-30. Cost savings from reduced venting and air sealing, as well as a 0.5 -ton reduction in air-conditioner capacity, are included, but are partially offset by the added cost to complete a HERS test for the duct leakage to outside test.

Table 18. Estimated Costs for NVA Strategy

\begin{tabular}{|c|c|c|c|c|c|c|}
\hline Description & $\begin{array}{c}\text { Roof Deck } \\
\text { Area } \\
\left(\text { ft }^{2}\right)\end{array}$ & $\begin{array}{c}\text { R-30 } \\
\text { Open } \\
\text { Cell Cost }\end{array}$ & $\begin{array}{c}\text { Venting/ } \\
\text { Air-Sealing } \\
\text { Savings }\end{array}$ & $\begin{array}{c}\text { Air-Conditioner } \\
\text { Downsizing } \\
\text { Savings }\end{array}$ & $\begin{array}{c}\text { HERS } \\
\text { Testing } \\
\text { Cost }\end{array}$ & $\begin{array}{l}\text { Total } \\
\text { Cost }\end{array}$ \\
\hline $\begin{array}{c}2,100-\text { ft }^{2} \text { One } \\
\text { Story }\end{array}$ & 2,275 & $\$ 3,462$ & $(\$ 475)$ & $(\$ 227)$ & $\$ 125$ & $\$ 2885$ \\
\hline $\begin{array}{c}2,700-\mathrm{ft}^{2} \mathrm{Two} \\
\text { Story }\end{array}$ & 1,571 & $\$ 2,441$ & $(\$ 475)$ & $(\$ 227)$ & $\$ 125$ & $\$ 1864$ \\
\hline
\end{tabular}




\subsubsection{High-Performance Attic Cost Details}

Data were borrowed from CEC (2015) to develop the cost estimates for implementing HPA. For the $2,100-\mathrm{ft}^{2}$ prototype, the incremental cost is estimated at $\$ 1,182$ and for the $2,700-\mathrm{ft}^{2}$ prototype the cost is estimated at $\$ 885$, including a $\$ 125$ cost for a DLO test.

\subsubsection{Buried Duct Cost Details}

The cost estimate for DBDs assumed an increase of attic insulation from R-30 to R-60 to cover ducts run close to the floor of the attic to achieve a weighted average duct R-value of 20 . An incremental cost for the insulation of $\$ 0.53 / \mathrm{ft}^{2}$ was added to a cost of $\$ 125$ for a DLO test. The total incremental costs used are $\$ 1,383$ and $\$ 1,059$ for the 2,100- and 2,700- $\mathrm{ft}^{2}$ prototypes, respectively. Although California Title 24 standards allow a compliance credit for DBDs, few if any builders are using it because of the difficulty and cost of verification, which are not included in the estimate.

\subsubsection{Cost Summary}

Costs for each advanced distribution system strategy are summarized in Table 19. The high and low costs for DCS reflect how compact duct design can influence the installation of ducts and chases for the attic and dropped-ceiling designs. The integrity of the thermal enclosure (walls, windows, and airtightness) also affects these costs because it influences the size of the HVAC system and therefore the size of the chases needed.

Modified "plenum" trusses that have been demonstrated by other Building America teams could further reduce the cost for building attic chases by reducing the cost of framing. The three builder partners in this project were not interested in pursuing this option, perhaps because of the cost of redesigning trusses for their stock plans.

Table 19. Summary of Estimated Advanced Distribution System Costs

\begin{tabular}{c|c|c|c}
\hline \multicolumn{2}{c|}{ Description } & $\begin{array}{c}\text { 2,100-ft } \\
\text { Prototype }^{2}\end{array}$ & $\begin{array}{c}\text { 2,700-ft } \\
\text { Prototype }^{2}\end{array}$ \\
\hline DCS-Dropped Ceiling & Low & $\$ 373$ & $\$ 286$ \\
& High & $\$ 811$ & $\$ 638$ \\
DCS-Attic Chase & Low & $\$ 1,003$ & $\$ 764$ \\
& High & $\$ 3,129$ & $\$ 2,388$ \\
HPA & & $\$ 1,182$ & $\$ 1,182$ \\
DBD & $\$ 1,383$ & $\$ 1,383$ \\
NVA & $\$ 2,885$ & $\$ 2,885$ \\
\hline
\end{tabular}

\subsection{Cost-Effectiveness Results}

Table 20 and Table 21 present cost-effectiveness results for the one-story and two-story prototypes, respectively, using an incremental cost per source kBtu metric. These results were developed from the BEopt projections of energy savings and the measure costs listed in Table 19. 
Table 20. 2,100-ft ${ }^{2}$ One-Story Prototype Cost-Effectiveness

\begin{tabular}{c|c|c|c|c|c}
\multicolumn{2}{c}{ Distribution Type } & \multicolumn{4}{c}{ (\$/kBtu) } \\
\cline { 3 - 6 } & & Phoenix & Fresno & Sacramento & Albuquerque \\
DCS - Dropped Ceiling & Low & $\$ 42$ & $\$ 62$ & $\$ 78$ & $\$ 47$ \\
& High & $\$ 92$ & $\$ 136$ & $\$ 170$ & $\$ 102$ \\
DCS - Attic Chase & Low & $\$ 113$ & $\$ 168$ & $\$ 210$ & $\$ 126$ \\
& High & $\$ 354$ & $\$ 524$ & $\$ 656$ & $\$ 392$ \\
\hline HPA & & $\$ 207$ & $\$ 321$ & $\$ 460$ & $\$ 523$ \\
\hline NVA & $\$ 176$ & $\$ 203$ & $\$ 227$ & $\$ 170$ \\
\hline
\end{tabular}

Table 21. 2,700-ft ${ }^{2}$ Two-Story Prototype Cost Effectiveness

\begin{tabular}{c|c|c|c|c|c|}
\hline \multicolumn{2}{|c|}{ Distribution Type } & \multicolumn{3}{c}{ Incremental Cost Relative to Source Energy Savings } \\
(\$/kBtu)
\end{tabular}

Because costs for locating ducts within conditioned space are dependent on specific floor plans and house designs, a broader range of costs was used to represent the two DCS strategies. The cost range is also intended to anticipate the learning curve that the industry will need to work through as it develops more cost-effective solutions. The results are also presented graphically in Figure 29. The blue (or orange) data point in the graph represents the average cost per kBtu saved across all the climates and the vertical bar represents the full range of project costs and can be viewed as the uncertainty or variability of these costs. 


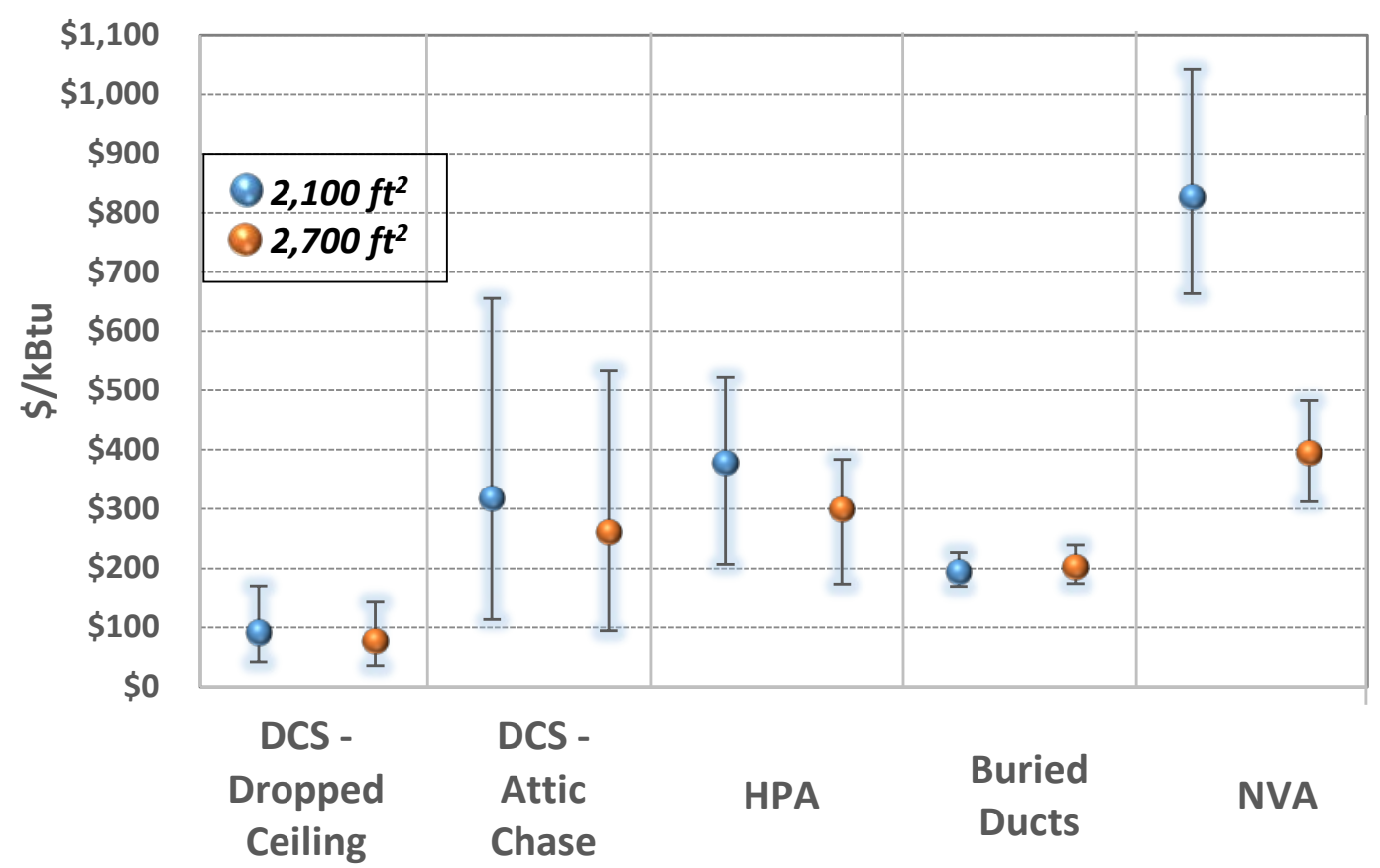

Figure 29. HPD projected cost-effectiveness range across modeled climates 


\section{Discussion}

\subsection{Differences between Models and Reality}

Simulation models such as BEopt allow inputs to define duct location. If "ducts in conditioned space" is selected, the model assumes that all energy that enters the duct finds its way to conditioned space and that no other heat transfers degrade DE. However, none of the highperformance approaches are $100 \%$ effective compared to a house with insulation at the ceiling and ducts installed inside occupied space, which is rarely observed in residential buildings.

For houses with NVAs, models can account for the increased surface area of the thermal enclosure (resulting in increased loads) and additional infiltration from the attic "zone" but may miss other effects. The observed differences between ODE and DEs calculated using Standard 152 is largely due to Standard 152's assumption that, unlike the ODE calculation, any duct heat transfer to the conditioned NVA is not lost thermal energy.

Ducts that are run through attic chases using modified trusses, or framed and sheathed chases as used by the three builders in this study may still have significant DLO because the duct connections and gaps in the duct chase are imperfectly sealed. All three of the DCS houses in this field study had measured leakage to outside. Attic duct chases increase the thermal enclosure surface area and, especially if they are not insulated to the same level as the ceiling, may increase heating and cooling loads. The thermograph shown in Figure 30 shows that the temperature inside the chase are several degrees $F$ warmer than the surrounding ceiling area, so losses to the attic are greater than for the rest of the ceiling. ${ }^{25}$

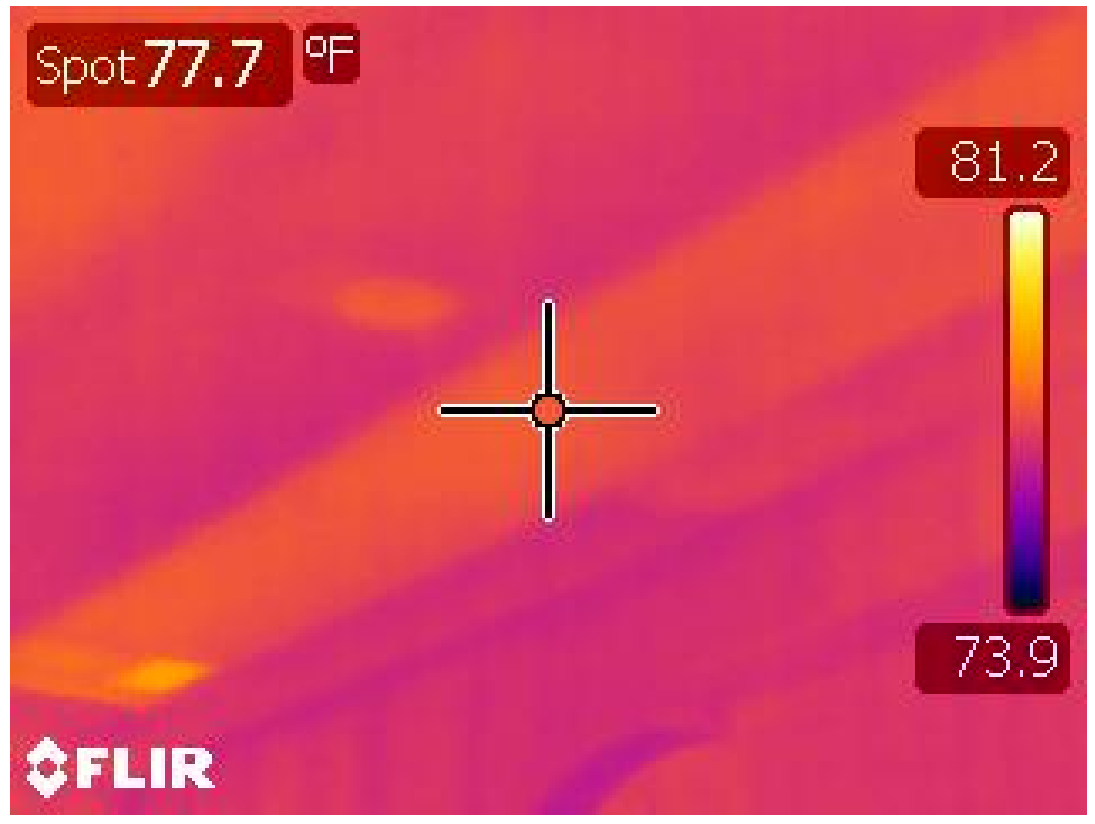

Figure 30. Infrared image of attic duct chase during heating operation

\footnotetext{
${ }^{25}$ Warmer area suggests added thermal gain to the chase, but is not clear about the fraction of the heat being recovered and the fraction being lost.
} 
Although comparing measured versus simulated DE involves much uncertainty, this exercise shows clearly that BEopt simulations overpredicted DCS performance for the cases evaluated in this study. This is largely because BEopt cannot directly model the implemented strategies that place ductwork in indirectly conditioned spaces (i.e., dropped ceilings or attic chases). Table 22 compares the measured (average of all like sites) seasonal DE that was developed using the Standard 152 method to the results from BEopt simulations. Except for the DCS case the results are remarkably close. The DCS DE could most certainly be improved through proper execution.

Table 22. Comparison of Measured and Simulated DE

\begin{tabular}{c|c|c}
\hline Case & $\begin{array}{c}\text { Measured Average } \\
\text { Seasonal DE }\end{array}$ & $\begin{array}{c}\text { BEopt Simulated } \\
\text { Seasonal DE }\end{array}$ \\
\hline 6\% Base & 87.7 & 87.0 \\
DCS & 91.4 & 100.0 \\
NVA & 91.4 & 92.0 \\
HPA & 89.9 & 90.0 \\
\hline
\end{tabular}

\subsection{Attic Chases and Compact Duct Designs}

Each of the three builders that implemented attic duct chases used slightly different strategies. In general the chases were much more expansive than they needed to be in cross-sectional dimensions and length. Chases could have been structured to tightly surround the ducts. The 28in. tall chase in one house was framed close to the top truss cord, leaving only a few inches for insulation above. The chases could have been shortened by as much as $40 \mathrm{ft}$ in one case, which would have saved cost (both in materials and labor) and reduced heat exchanges with the attic.

The chases should be sealed before the ducts are installed. Drywall lining appeared to be easier to seal. The fire-taped chase used at site A-1 yielded an effectively airtight chase. OSB as a material for lining the chases was apparently more difficult to seal. Leakage to the outside at Sites A-6 and A-7 was measured as about $25 \%$ of total duct leakage.

Many of the challenges observed in the project highlight the learning curve associated with a builder's first foray into HPD implementation. The participating builders deserve a high commendation for their effort and dedication in finding solutions that met the requirements of the project and their own needs. This is a process and the builders came out of the study with better ideas about how to improve on HPD implementation. When its advanced DCS home was completed, Wathen Castanos noted that it would follow a very different path in its next DCS attempt. The attic mechanical closet (attic doghouse) was especially problematic. The enclosure was a challenge to air seal and insulate and trade coordination was particularly challenging because the subcontractors were not fully prepared to undertake this change.

\subsection{Cabinet Leakage}

HERS raters commonly tape furnaces and cooling coil cabinets thoroughly before they test ducts for leakage. The tape is frequently removed after testing to permit access to the units. Leakage from the furnace or heat pump AHU cabinets can be a significant problem for HPA and DBD systems where this equipment is installed in a vented attic. Placing the equipment within conditioned space eliminates the thermal losses to unconditioned space. Some builders assign a very high value to the floor space, but unless cabinet airtightness standards (ASHRAE Standard 
193 - see also PNNL 2014) are applied, moving this equipment into conditioned space is important to achieving DEs higher than $90 \%$.

Homes built in the 1950s to 1970s typically have equipment installed in indoor closets. The shift to attic locations in the 1980 s was probably made to free up floor space, solve combustion air problems, and reduce cost. The U.S. Department of Energy is moving to standards that will require annual fuel utilization efficiencies of at least $92,{ }^{26}$ so the combustion air problem will be easier to solve because most furnaces will be direct vented using polyvinyl chloride pipe.

\subsection{A Comprehensive Approach to HVAC Efficiency}

Applying his many years of diagnostic testing of homes and HVAC units throughout California and the southwestern United States, Rick Chitwood developed a holistic prescription for optimizing HVAC performance for ZERHs in dry climates. Summarized in Table 23, the process requires careful attention to design and includes verification steps that are different than or complementary to checklists used in California standards and by ENERGY STAR. The focus on testing to demonstrate in-situ performance facilitates feedback to the installing contractor about where the system is not meeting performance targets.

Table 23. Specification of Optimized "Hot-Dry" HVAC Performance for ZERHs

\begin{tabular}{|c|c|}
\hline Parameter & Acceptance Criteria \\
\hline Duct Location & $\begin{array}{l}\text { Visual inspection to confirm ducts are located in conditioned } \\
\text { space confirmed with duct leakage test result }\end{array}$ \\
\hline Duct Leakage & $<5$ CFM25 leakage to outside using Ring 4 on the duct blaster \\
\hline Duct Insulation & $\mathrm{R}-8$ \\
\hline Maximum Heating Capacity & Heating capacity $<10 \mathrm{Btu} / \mathrm{ft}^{2}$ \\
\hline Furnace Temperature Rise & $\begin{array}{l}\text { Measured temperature rise across the furnace heat exchanger is } \\
<5^{\circ} \mathrm{F} \text { above minimum specified by the manufacturer }\end{array}$ \\
\hline Furnace Sizing Confirmation & $\begin{array}{l}\text { System operates a minimum } 70 \% \text { of the hour to maintain steady- } \\
\text { state } 71^{\circ} \mathrm{F} \text { indoor set point under design heating conditions }\end{array}$ \\
\hline $\begin{array}{l}\text { Supply Grille Delivery } \\
\text { Velocity (Both Heating and } \\
\text { Cooling Operation) }\end{array}$ & $\begin{array}{l}\text { Measured velocity is } 500-700 \mathrm{ft} / \text { minute based on measured } \\
\text { register airflow and grille manufacturer's data }\end{array}$ \\
\hline Maximum Cooling Capacity & Nominal cooling capacity $>1200 \mathrm{ft}^{2} /$ ton \\
\hline $\begin{array}{l}\text { Air-Conditioner Sizing } \\
\text { Confirmation }\end{array}$ & $\begin{array}{l}\text { System operates a minimum } 70 \% \text { of the hour to maintain steady } \\
\text { state } 74^{\circ} \mathrm{F} \text { indoor set point under design cooling conditions }\end{array}$ \\
\hline Cooling System Airflow & $\begin{array}{l}>550 \mathrm{CFM} / \text { ton measured at return with condensing unit off (will } \\
\text { get sensible heat ratio close to } 1.0 \text {, which is appropriate for hot- } \\
\text { dry climate applications) }\end{array}$ \\
\hline Verified Refrigerant Charge & $\begin{array}{l}\text { Superheat and subcooling within } 1^{\circ} \mathrm{F} \text { of minimum specified by } \\
\text { manufacturer with liquid line between } 98^{\circ} \text { and } 102^{\circ} \mathrm{F}\end{array}$ \\
\hline $\begin{array}{l}\text { Measured Sensible Energy- } \\
\text { Efficiency Ratio }\end{array}$ & $\begin{array}{c}>90 \% \text { of manufacturer's reported energy-efficiency ratio at } 95^{\circ} \mathrm{F} \\
\text { outdoor temperature with capacity measured as the sum of the Btu } \\
\text { delivered at each register (measured airflow, register versus return } \\
\text { air temperature difference) }\end{array}$ \\
\hline $\begin{array}{l}\text { Forced-Air Unit Fan Watt } \\
\text { Draw }\end{array}$ & $<0.2 \mathrm{~W} / \mathrm{CFM}$ (measured W divided by measured system airflow) \\
\hline
\end{tabular}

${ }^{26}$ http://energy.gov/eere/buildings/downloads/2015-02-10-issuance-energy-conservation-standard-residentialfurnaces 


\section{Conclusions and Recommendations}

\subsection{What Do the Results Reveal?}

This project covered a wide range of activities relative to assessing the performance, economics, and implementation issues related to HPD systems in hot-dry climates. In California, where the fieldwork was completed, the building industry is beginning to realize that HPD systems will be a key component of the zero energy homes that will need to be built by 2020 .

Based on the costs obtained, assumptions applied in this project, and modeled performance, DCS with ducts below the ceiling plane (or "dropped") are the most cost-effective, followed by DBD, DCS with attic duct chases, HPA, and NVA. However, costs for the dropped-ceiling strategy were estimates; additional work is warranted to collect more robust as-built incremental cost data. More accurate modeling and creative solutions to reduce costs could completely alter this order. Each option has its own benefits and problems that builders, their architects, and HVAC contractors must address as they integrate HPD strategies with their house designs.

Both DCS strategies (dropped-ceiling and attic chases) were projected by BEopt to reduce HVAC source energy by $8 \%$ on average for the two-story prototype and $12 \%$ on average for the one-story prototype relative to the Benchmark with $6 \%$ duct leakage. Variations in the percentage of energy savings were minimal among the four climates evaluated. However, BEopt cannot recognize the energy impact of an added enclosure area associated with the attic chase DCS strategy.

Moving ducts and equipment fully into conditioned space has the potential to provide the greatest efficiency of any of the alternatives. The preference of three of the participating builders to build duct chases above the ceiling plane was more costly than some of them anticipated, and the ducts were not sealed and insulated sufficiently to be considered truly within conditioned space. Building a mechanical space in the attic proved to be much costlier than installing the equipment in a closet at floor level, even when considering the value of lost living space. These efforts represent the builders' first attempts to build with DCS. Coming out of the process, all three builders had better ideas about how they would implement DCS in their next attempts.

Using dropped ceilings, soffits, and chases furred below the ceiling plane avoids adding surface area to the thermal enclosure and simplifies the sealing process. However, all three of the DCS builders chose to steer away from dropped ceilings. A key concern was a perception that the home-buying market strongly prefers open, airy, floor plans. Full-height ceilings (even in hallways, utility areas, and closets where ceiling drops can normally be run) are an important piece of marketing their homes, and builders and their marketing staff seem convinced that buyers will be put off by the architectural impact. However, lower cooling and heating loads with ZERHs and subsequently smaller duct requirements may help mitigate the aesthetic impact of dropped ceilings. Buyers must be educated about the benefits of an HPD home and how those features may create an environment different from the mass market of available products. Just as photovoltaic systems have evolved beyond being viewed as impossible eyesores, dropped ceilings may be accepted as a sign of improved construction quality.

Meritage Homes and other builders have landed on NVAs (which have many benefits) as the preferred solution. One benefit that has not been mentioned in this report is that they eliminate 
concerns about air leakage through fire sprinklers. However, when builders begin to experience the cost of insulating the roof deck to R-30 or higher, they may begin to seek other alternatives, or at least lower cost methods of insulation besides spray foam.

Modeling results make HPAs appear to be an attractive, reasonably cost-effective alternative to DCS that perform almost as well as NVAs and achieve source energy savings as high as $65 \%$ of that for true DCS. The ARBI team did not have the opportunity to measure the seasonal effectiveness of HPA systems, but the modeling results need to be validated. Given that HPA has become a recognized compliance option under California's 2016 Title 24 standards, opportunities to measure field performance will likely arise.

The DBD option looks favorable based on its low cost and simple implementation. A major part of the energy savings stems from doubling the ceiling insulation R-value. On average the DBD strategy with R-60 ceiling insulation is projected to save $8 \%$ more energy than DCS for the onestory and $14 \%$ more for the two-story prototype.

As revealed by this project, the primary barriers to the adoption of advanced high-performance distribution systems include increased cost, builder-perceived risk related to market acceptability, builder and contractor risk associated with proper sizing, HVAC contractor resistance to change, and lack of planning for equipment and duct locations.

As with any emerging technology or practice, costs will remain high until these strategies are widely adopted. For mature market costs to be realized, coordination and teamwork are required that engage the architect, builder, and affected subcontractors. In the near term, this lack of coordination will continue to be the biggest obstacle to reducing the cost of advanced distribution strategies. Currently NVA and HPA approaches can be implemented with minimal changes to the architecture, and in volume applications current costs are probably close to being mature. Although these strategies may not provide the ideal solution, they can serve as a midpoint on the road to more efficient DCS strategies.

Other less mainstream alternatives that have been used for custom homes and could be applied to production homes include mini-split or multi-split heat pumps and air-to-water heat pumps with hydronic distribution. Although these systems offer advantages over gas-electric systems in some applications, they must overcome market acceptance and cost barriers. Current market trends suggest that furnaces and air conditioners will remain the predominant HVAC system types for many years in California and other areas where natural gas is available.

\subsection{Overcoming Barriers}

Continued demonstrations of HPD are needed to encourage the use of integrated design principles and to help builders learn to how to work as a team with their architects, subcontractors, and vendors to develop high-performance, low-cost distribution system solutions. Carefully designed demonstration homes built with ducts in dropped ceilings can be used to promulgate information about how HPD can be an architectural feature and a cost-effective energy amenity. This awareness needs to be shared with the building community and the buying public.

Reduced duct loss, lower thermal loads, and smaller HVAC systems are synergistic. Field demonstrations should include rightsizing HVAC systems and compact duct design so the space 
requirements for ducting are reduced. Testing and homeowner testimonials are needed to spread awareness that well-designed compact duct systems provide comfort that is at least on par with traditional methods. The experiences of early builders and implementers of high-performance distribution systems and optimized HVAC installations need to be captured in case studies that document the design and construction processes and costs. Continued reporting on how builders are evolving these practices will help others reduce costs and meet market demands.

Builders in the residential sector rely on the experience and knowledge of their HVAC contractors to design systems that meet homeowner comfort needs and minimize complaints and callbacks. The relationship of trust between builders and their contractors is usually built up over several years. Historically it has been based on delivering a low first-cost installation with adequate performance and minimal builder liability. To achieve ZERH specifications, this relationship will need to evolve to the point at which performance is paramount as reflected in correctly sized equipment; improved matching of air delivery to room-by-room loads; registers that provide proper throw for a compact duct design; and properly sized ducts, grilles, and filters that improve airflow and reduce fan power. Current and next-generation HVAC contractors and installers need training to dispel tightly held beliefs about how systems should be sized and such misconceptions as the need to extend ducts to exterior walls in high-performance homes.

More field performance data are needed, especially to verify that the HPA strategy can yield the performance projected by the models. More study of the performance of houses with NVA systems is also needed to understand the whole-house impacts and values of this strategy. 


\section{References}

ASHRAE. 2004. Method of Test for Determining the Design and Seasonal Efficiencies of Residential Thermal Distribution Systems (ASHRAE Standard 152-2004). Atlanta, GA: American Society of Heating, Ventilating and Air-Conditioning Engineers.

Beal, D., McIlvaine, J., Fonorow, K., and Martin, E. 2011. Measure Guideline: Summary of Interior Ducts in New Construction, Including an Efficient, Affordable Method to Install FurDown Interior Ducts. Golden, CO: National Renewable Energy Laboratory. DOE/GO -1020113421. http://www.fsec.ucf.edu/en/publications/pdf/FSEC-RR-385-11.pdf.

Burdick, A. 2013a. Strategy Guideline: Compact Air Distribution Systems. Golden, CO: National Renewable Energy Laboratory. DOE/GO -102013-3846.

http://apps 1.eere.energy.gov/buildings/publications/pdfs/building_america/strategy guide comp act air dist.pdf.

Burdick, A. 2013b. Measure Guideline: Implementing a Plenum Truss for a Compact Air Distribution Systems. Golden, CO: National Renewable Energy Laboratory. DOE/GO -1020134017.

CEC. 2015. Residential Ducts in Conditioned Space/High Performance Attics. Sacramento, CA: California Energy Commission.

http://www.energy.ca.gov/title24/2016standards/rulemaking/documents/dru title24_parts_01_06 12016\%20T24\%20CASE\%20Report\%20-\%20HPA - DCS 2015-02-06 TN-74503.pdf

Earth Advantage Institute. 2011. "Building with Ducts in Conditioned Space." Portland, OR. https://ductsinside.files.wordpress.com/2011/04/ducts-inside-training-manual.pdf.

Grin, A., Smegal, J., and Lstiburek, J. 2013. Application of Spray Foam Insulation Under Plywood and Oriented Strand Board Roof Sheathing. Golden, CO: National Renewable Energy Laboratory. DOE/GO -102013-4257. www.nrel.gov/docs/fy14osti/60431.pdf.

Hales, D., and Baylon, D. 2010. "Moving Ducts into Conditioned Space: Getting to Code in the Pacific Northwest.” ASHRAE Transactions 116, Part 1.

Lubliner, M., Kerr, R., Gordon, A., and Murray, C. 2008. "Moving Ducts Inside: Big Builders, Scientists Find Common Ground." Proceedings of the 2008 ACEEE Summer Study on Energy Efficiency in Buildings.

PNNL. 2014. "HVAC Cabinet Air Leakage Test Method.” Richland, WA: Pacific Northwest National Laboratory. http://energy.gov/sites/prod/files/2014/12/f19/ba_innovations_2014 hvac airleakage.pdf.

Proctor, J., Chitwood, R., and Wilcox, B.A. 2011. Efficiency Characteristics and Opportunities of New California Homes. Sacramento, CA: California Energy Commission. CEC-500-2012062. http://www.energy.ca.gov/2012publications/CEC-500-2012-062/CEC-500-2012-062.pdf. 
Rutkowski, H. Manual D—Residential Duct Systems, 3rd Edition. Arlington, VA: Air Conditioning Contractors of America. 2009a.

Rutkowski, H. Manual S-Residential Equipment Selection. Arlington, VA: Air Conditioning Contractors of America. 2009b.

Rutkowski, H. Manual T-Air Distribution Basics for Residential and Small Commercial Buildings. Arlington, VA: Air Conditioning Contractors of America. 2009c.

Rutkowski, H. Manual J—Residential Load Calculation, 8th Edition. Arlington, VA: Air Conditioning Contractors of America. 2011.

Shapiro, C., McGee, A., and Zoeller, W. 2013. Reducing Thermal Losses and Gains With Buried and Encapsulated Ducts in Hot Humid Climates. Golden, CO: National Renewable Energy Laboratory. DOE/GO -102013-3719.

http://apps1.eere.energy.gov/buildings/publications/pdfs/building_america/encaps_ducts_hothum id.pdf.

Siegel, J., McWilliams, J., and Walker, I. 2002. "Comparison Between Predicted Duct Effectiveness from Proposed ASHRAE Standard 152 and Measured Field Data for Residential Forced Air Cooling Systems.”. Berkeley: Lawrence Berkeley National Laboratory report \#50008. http://epb.lbl.gov/publications/pdf/lbnl-50008.pdf.

Springer, D., Dakin, B., and Backman, C. 2012. A Feasibility Study: Ductless Hydronic Distribution Systems with Fan Coil Delivery.” Golden, CO: National Renewable Energy Laboratory. DOE/GO-102012-3629. apps1.eere.energy.gov/buildings/publications/pdfs/building america/ductless hydronic dist.pdf.

Ueno, K., and Loomis, H. 2014. Long-Term Monitoring of Mini-Split Ductless Heat Pumps in the Northeast. Golden, CO: National Renewable Energy Laboratory. DOE/GO-102014-4529.

Wilson, E., Engebrecht Metzger, C., Horowitz, S., and Hendron, R. 2014. 2014 Building America House Simulation Protocols. Golden, CO: National Renewable Energy Laboratory. NREL/TP-5500-60988. 


\section{Appendix A: Builder Recruitment Process}

Site selection proceeded through various avenues:

- DEG presented a webinar on July 15, 2013 in conjunction with Matt Christie (program manager for PG\&E's CAHP program) to introduce HERS raters and CAHP builders to the PG\&E Emerging Technology Program opportunity for high-performance walls and ducts.

- DEG's ongoing work running LEED for Homes in California and Building America research efforts puts us in front of many of the progressive builders in California, although many are small-scale builders or semicustom builders.

- Direct outreach to builders and contacts within the utility industry working on advanced residential building initiatives.

- Contact with Title 24 compliance companies and through the California Association of Building Energy Consultants.

- Attendance at PCBC in San Diego as well as several Building Industry Association events in the greater Sacramento area.

Each option was explored to identify and communicate with potential builder candidates. In a few cases builders were currently implementing the technology to the specifications identified for the project (or close to the project specifications), but generally the recruitment process required talking through the advanced measures, providing information on the expected benefits of the technology, and working within their decision-making framework to determine if there was an opportunity to engage the builder in the project. The site selection process did not occur over a discrete time window, as the team had originally anticipated when developing the project statement of work. All the builders proceeded on their own schedules as they worked through a range of issues that included:

- Gathering more information on the project opportunity

- Completing internal reviews within their organization to determine if the project opportunity was worth pursuing

- Discussing with their subcontractors their ability and desire to implement potential approaches and expected costs

- Focusing on ongoing construction activities as the market rebounded.

Builders that were identified and contacted and chose not to participate in the project are listed in Table 24. 
Table 24. Builders Contacted Who Chose Not To Participate

\begin{tabular}{|c|c|c|c|}
\hline Builder & Location(s) & Discussion of Measures & Reason for Not Participating \\
\hline $\begin{array}{l}\text { Taylor } \\
\text { Morrison }\end{array}$ & Rocklin & $\begin{array}{l}\text { Currently using } 2 \times 6 \text { wall } \\
\text { construction with } 1 \text {-in. R-4 } \\
\text { exterior in Rocklin project }\end{array}$ & $\begin{array}{l}\text { Not interested in hassles } \\
\text { associated with utility } \\
\text { programs; too busy }\end{array}$ \\
\hline $\begin{array}{l}\text { Cresleigh } \\
\text { Homes }\end{array}$ & Yuba City & $\begin{array}{l}\text { Have done some } 2 \times 6 \text { walls } \\
\text { in the past }\end{array}$ & $\begin{array}{l}\text { No projects with } 2 \times 6 \\
\text { currently planned }\end{array}$ \\
\hline $\begin{array}{l}\text { Pulte } \\
\text { Homes }\end{array}$ & $\begin{array}{l}\text { Lincoln, East } \\
\text { Bay, San Jose }\end{array}$ & $\begin{array}{l}\text { Conditioned attics in some } \\
\text { areas where they build }\end{array}$ & $\begin{array}{l}\text { Too busy to focus on this } \\
\text { effort. }\end{array}$ \\
\hline $\begin{array}{c}\text { Shea } \\
\text { Homes }\end{array}$ & Rio Vista & $\begin{array}{l}\text { Prior limited experience } \\
\text { with conditioned attics }\end{array}$ & $\begin{array}{l}\text { Original contact we were } \\
\text { pursuing left the company; } \\
\text { further follow-ups were not } \\
\text { responded to }\end{array}$ \\
\hline $\begin{array}{l}\text { Lennar } \\
\text { Homes }\end{array}$ & Fresno & $\begin{array}{l}\text { Building higher } \\
\text { performance homes in area }\end{array}$ & $\begin{array}{c}\text { Too busy to focus on this } \\
\text { effort. }\end{array}$ \\
\hline $\begin{array}{l}\text { Elliott } \\
\text { Homes }\end{array}$ & Folsom & $\begin{array}{l}\text { Building high-performance } \\
\text { homes with } 2 \times 6 \text { walls and } \\
\text { DCS (but not HVAC unit) }\end{array}$ & $\begin{array}{l}\text { Working under Sacramento } \\
\text { Municipal Utility district high- } \\
\text { performance home program; } \\
\text { initiated a dialogue, but they } \\
\text { ultimately decided not to } \\
\text { participate }\end{array}$ \\
\hline KB Homes & $\begin{array}{c}\text { Greater } \\
\text { Sacramento area, } \\
\text { Fresno, Stockton }\end{array}$ & $\begin{array}{c}\text { Have built advanced homes } \\
\text { with various measures, but } \\
\text { not apparently in northern } \\
\text { California }\end{array}$ & $\begin{array}{l}\text { Initial lukewarm interest, but } \\
\text { decided not to participate }\end{array}$ \\
\hline $\begin{array}{l}\text { Clarum } \\
\text { Homes }\end{array}$ & & $\begin{array}{l}\text { Lighting, structurally } \\
\text { insulated panel walls }\end{array}$ & Only custom homes underway \\
\hline Landmark & & & $\begin{array}{l}\text { Initial interest at Building } \\
\text { Industry Association event, but } \\
\text { follow-up was not successful }\end{array}$ \\
\hline $\begin{array}{l}\text { New Home } \\
\text { Company }\end{array}$ & $\begin{array}{l}\text { Will be building } \\
\text { advanced homes } \\
\text { in } 2015\end{array}$ & & $\begin{array}{c}\text { Some interest, but not in the } \\
\text { near term. Projects starting Q4 } \\
2014\end{array}$ \\
\hline $\begin{array}{c}\text { K } \\
\text { Hovananian }\end{array}$ & & $\begin{array}{l}\text { Haven't implemented but } \\
\text { are interested in staying } \\
\text { informed }\end{array}$ & $\begin{array}{l}\text { No projects in the short term } \\
\text { where they are considering } \\
\text { these measures }\end{array}$ \\
\hline JMC & & & $\begin{array}{l}\text { Limited interest, but haven't } \\
\text { implemented previously }\end{array}$ \\
\hline Signature & & & $\begin{array}{l}\text { Building multifamily, but no } \\
\text { projects until the fall }\end{array}$ \\
\hline
\end{tabular}




\section{Appendix B: Field Data Collection Procedures \\ SHORT-TERM DUCT TESTING PROTOCOL PG\&E Emerging Technologies Project}

The goal of the duct short-term testing protocol is to characterize the performance of duct systems in the field and to describe the system DE (i.e. the ability to transfer useful energy from the furnace or AHU to the supply registers). The collected data will be used with the ASHRAE 152 methodology to derive DE. The proposed method involves:

1. Measurement of system airflow (using plenum pressure matching technique), fan watt draw, operating static pressure, and representative supply air temperature at the unit during "high" load conditions. ${ }^{27}$

2. Measurement of total duct leakage at $25 \mathrm{~Pa}$ and disaggregation of leakage into supply and return leakage using the Half Nelson procedure (described in Step 2 below).

3. Measurement of duct inlet temperature (measured at supply plenum start collar) and supply register delivery temperatures and individual supply airflows (using TEC Flow Blaster).

4. Calculation of energy loss/gain from the furnace or AHU to the supply registers.

5. Calculate ASHRAE 152 design and seasonal duct efficiencies based on collected and calculated site data.

\footnotetext{
${ }^{27}$ Measurements should be taken early AM during cold winter nights or later PM during hot summer days .
} 


\section{Step 1: Measurement of System Airflow, Fan Watt Draw, and Operating Static pressure}

Measurements will be made in accordance with procedures specified in the CEC Residential Reference Appendices (see section RA3.3 in the link below). Acceptable airflow measurement techniques include plenum pressure matching or use of a flow grid device. Static pressure readings will be taken in accordance with section RA3.3.1.1 of the 2013 Title 24 Reference Appendices found at:

http://www.energy.ca.gov/2012publications/CEC-400-2012-005/CEC-400-2012-005-15DAY.pdf

Enter:

Measured operating static pressure

Heating operation: in. w.c.

Cooling operation: in. w.c.

Measured operating fan watt draw

Heating mode:

W

Cooling mode:
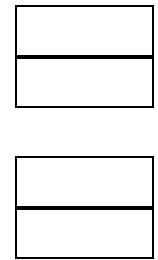

CFM
CFM

Step 2: Measurement of duct leakage and disaggregation of total leakage into supply and return leakage components using the half-Nelson technique documented below.

A standard duct pressurization test at 25 Pascals will be completed in accordance with procedures specified in the CEC Residential Reference Appendices (see section RA3.1.4.3.2.1 in the link above). A second test at 25 Pascals will be completed to assess DLO as per RA3.1.4.3.4.

The Half-Nelson procedure involves fully sealing all supply and return registers and then operating the supply fan. Airflow can only be generated via leakage in the supply and return duct system, plenums, and AHU. Supply and return plenum pressures are recorded. The premise of the Half-Nelson is that flow through the leaks can be represented as flow through an orifice. The following calculations derive the Half Nelson method.

Definition of terms:

$\begin{array}{lll}\mathrm{LA} & = & \text { leakage area, } \mathrm{in}^{2} \\ \mathrm{~L} & = & \text { leakage, } \mathrm{CFM} \\ \mathrm{CFM}_{25}= & \text { measured total system Duct Blaster leakage at } 25 \mathrm{~Pa} \\ \mathrm{SP}= & \text { static pressure, Pa } \\ \mathrm{abs}= & \text { absolute value }\end{array}$

Definition of subscripts:

$\begin{array}{lll}\mathrm{S} & = & \text { supply } \\ \mathrm{r} & = & \text { return } \\ \mathrm{T} & = & \text { total } \\ \mathrm{o} & = & \text { operating pressure }\end{array}$


1. $\frac{L A s}{L A r}=\sqrt{S P r / S P s}$

2. $L A_{T}=L A_{S}+L A_{r}$

3. $L A_{T}$

$=L A_{r} * \sqrt{S P r / S P S}+L A_{r}$

4. $\frac{L A T}{L A r}$

5. $\frac{1}{L A r}$

6. $L A_{r}$

7. $L=1.07 * L A * \sqrt{a b s(S P o})$

8. CFM $_{25}=1.07 * L A_{T} * \sqrt{25}$
Half Nelson Assumption

Substitute LA from 1 into 2.

Divide each side by $\mathrm{LA}_{r}$

Divide each side by $\mathrm{LA}_{T}$

Invert Equation 5

Defines leakage through an orifice

From Duct Blaster test

Solve Eqn 8 for $\mathrm{LA}_{\mathrm{T}}$ and substitute in Eqn 6. $\mathrm{SP}_{\mathrm{r}}$ and $\mathrm{SP}_{\mathrm{s}}$ measured during Half-Nelson
9. $L A_{r}$
$=\left(0.187 * C F M_{25}\right) /(1+\sqrt{S P r / S P S})$

Equation 9 solves for $L A_{r}$ as a function of the Duct Blaster leakage $\left(C F M_{25}\right)$ and the Half-Nelson supply and return plenum pressures $(S P r$ and $S P S)$. Equation 7 can now be used to calculated return and supply leakage flow.
10.. $L_{r}$
$=1.07 * L A_{r} * \sqrt{\operatorname{abs}\left(S P_{r_{0}}\right)}$
11. $L_{S}$
$\left.=1.07 * L A_{s} * \sqrt{\operatorname{abs}\left(S P S_{o}\right.}\right)$

With the presumption that $C F M_{25}$ is the "correct" representation of total leakage, the final step involves apportioning the leakage flows in Equations 10 and 11 to arrive at the final estimate of return leakage, $L_{r}$.
12. $L_{r}$
$=\frac{L_{r} * C F M_{25}}{\left(L_{r}+L_{s}\right)}$
apportioned leakage

$L_{r}$ is then added to the return fan flow (measured with the Duct Blaster at the return) to arrive at system fan flow (SFF), which is the total air flow passing across the furnace or cooling coil. SFF is also the basis for apportioning supply air flow using a flow hood at each of the supply registers.

The total airflow delivered at registers (CFM) is then calculated as the SFF minus the supply leakage. 
$\underline{\text { Step 3: Measurement of supply temperatures and register airflows }}$

Tests should be conducted during the time of day when we have a maximum indoor to outdoor temperature difference. That means cold early mornings mid-winter for heating season testing, and late summer afternoons for cooling season testing.

Procedure as follows:

1. Install special limits of error thermocouple sensors into supply duct start collar (at supply plenum connection) and supply registers.

2. Set HVAC thermostat to cooling or heating (depending on season) and set points that are at least $8^{\circ} \mathrm{F}$ from the current indoor temperature. This will insure a long steady-state operating cycle that will allow for all the measurements to be completed without the system shutting off. If the system is multi-stage, maintain a sufficient offset to insure high speed operation continually. If needed to maintain reasonable indoor temperatures, open windows to bring in outdoor air to offset HVAC operation.

3. Allow the system (furnace, heat pump or AC) to operate for at least 15 minutes before taking any measurements.

4. Measure attic temperature with the Vaisala and note the time of measurement. If there are multiple attic spaces (or other duct location environments), measure and record the temperature (and time of measurement) for each.

5. Measure temperatures at each supply grille using the Vaisala, and record time and coincident supply plenum temperatures at the time of the supply register readings. Verify supply temperature measure has stabilized before recording reading for each register.

6. After all supply grille measurements are completed measure the attic temperature(s) again, noting the time.

7. Repeat Step 5.

8. While system still operating, measure the airflow at each register using the flow hood. Apportion the system fan flow (airflow through the furnace or AHU) using the individual flow hood measurements.

\section{Enter the following information:}

Date/time of start of HVAC operation:

Coincident outdoor temperature:

Coincident indoor temperature:

Coincident duct environment temperature (include measurement point at AHU):

Environment Information: enter descriptive name, temperature and time

Example: Environment \#1: attic (10 ft from supply plenum at $4 \mathrm{ft}$ height), $43.5^{\circ} \mathrm{F}, 8: 13 \mathrm{a} . \mathrm{m}$.

Environment 1:

Environment 2:

Environment 3:

Environment 4:

Begin supply air readings a minimum of 5 minutes after start of HVAC operation 
Record temperatures and time of reading for each register in the house as noted on the duct layout sketch (see Attachment 1). After completion of measurements, complete a second round of readings in the same order.

\begin{tabular}{|r|r|r|r|r|l|}
\hline \multicolumn{1}{|c|}{$\begin{array}{c}\text { Register } \\
\text { ID }\end{array}$} & \multicolumn{2}{|c|}{ First Round of Readings } & & \multicolumn{2}{|c|}{ Second Round of Readings } \\
\hline & Time & Temperature & & Time & Temperature \\
\hline SupPlen & & & S1 & & \\
\hline Return Air & & & S2 & & \\
\hline S1 & & S3 & & \\
\hline S2 & & S4 & & \\
\hline S3 & & S5 & & \\
\hline S4 & & S6 & & \\
\hline S5 & & & S7 & & \\
\hline S6 & & S8 & & \\
\hline S7 & & S9 & & \\
\hline S8 & & & S10 & & \\
\hline S9 & & S11 & & \\
\hline S10 & & S13 & & \\
\hline S11 & & S14 & & \\
\hline S12 & & SupPlen & & \\
\hline S13 & & Return Air & & \\
\hline S14 & & & & & \\
\hline & & & & &
\end{tabular}

After completion of second round of readings, record the following:

Coincident outdoor temperature:

Coincident indoor temperature:

Coincident duct environment temperature (include point at $\mathrm{AHU}$ ):

Environment 1:

Environment 2:

Environment 3:

Environment 4:

End of test. 


\section{Appendix C: Testing of 20 Meritage Nonvented Attic Homes}

\section{Overview}

This testing report summarizes whole-house and attic envelope leakage testing completed by Rick Chitwood in homes with cathedralized attics. This construction technique is used in all Meritage Homes nationally and uses open-cell spray foam insulation at the roof deck and at all exterior walls. Meritage has been touting the energy-efficiency attributes of this construction and feels that current Title 24 modeling rules do not fairly credit this construction method. The testing was completed primarily to provide a more detailed characterization of performance of these homes in northern California.

In the fall of 2014, a 20-home sample was accurately tested to document their envelope and duct leakage characteristics and explore testing challenges. The homes were located in six Meritage subdivisions in the following locations:

- El Dorado Hills (six homes, two subdivisions)

- Lincoln (four homes)

- Fairfield (three homes)

- Roseville (seven homes, two subdivisions).

These homes were insulated by two spray foam insulation contractors and HVAC installations were completed by three mechanical contractors.

The measured envelope infiltration and measured duct leakage results were compared to the recorded HERS verification measurements on these homes.

\section{Testing Challenges}

In addition to completing the testing, we observed several challenges and areas of uncertainty related to the Title 24 test requirements. These are listed below and discussed in more detail at end of this report.

Testing challenges:

- Passive outdoor air duct

- Fan forced outdoor air duct

- Automatic bathroom exhaust fans that are on at a low CFM constantly

- Automatic bathroom exhaust fans controlled by occupancy sensors and off delays

- Automatic bathroom exhaust fans controlled by humidistats

- Zoning

- Heat recovery ventilators and energy recovery ventilators.

Testing challenges in homes with cathedralized (NVA) attics:

- Lack of guidance on how these homes should be tested

- Position of attic access hatch during testing 
- Meeting the $25 \mathrm{CFM}_{25}$ DLO criteria for DCS

- Complex attics that are partially cathedralized

- High total duct leakage that can overcool or overheat the conditioned attic, rather than delivering to the indoor space.

\section{Air Infiltration Testing Procedure}

Testing was performed to measure the total amount of air infiltration (and fraction of wholehouse infiltration) that is associated with the attic when both the house and conditioned attic are pressurized to $50 \mathrm{~Pa}$, as well as the pressure difference across the ceiling assembly (which represents an interior partition in a cathedralized attic house).

The following four tests were performed on each cathedralized attic home. A fairly standard air infiltration test was performed with both the attic hatch open and the attic hatch closed.

- Blower door test (attic hatch closed). Single point house pressurization test (depressurized blower door test) with attic hatch closed (with pre and post baselines, 1 minute average, and calibrated gauge).

- Record the attic pressure with respect to the house (1 minute average, calibrated gauge).

- Blower door test (attic hatch open). Single-point house pressurization test (depressurized blower door test) with attic hatch open (with pre and post baselines, 1-minute average, and calibrated gauge).

- Attic leakage. Measure attic leakage with a duct blaster in the attic hatch (cruise "zero" while the home is depressurized to 50 Pascals).

\section{Duct Leakage Testing Procedure}

The following three duct leakage tests were performed. Two fairly normal duct leakage tests to the outside were done, one with the attic hatch open and one with the attic hatch closed. The third test was a standard total duct leakage test.

- Duct leakage to the outside test with attic hatch open. Duct Blaster test with pressurized ducts (house pressurized to 25 Pascals, use Duct Blaster ring 4 if needed, 10 second average, and calibrated gauge).

- Duct leakage to the outside test with attic hatch closed. Duct Blaster test with pressurized ducts (house pressurized to 25 Pascals, use Duct Blaster ring 4 if needed, 10 second average, and calibrated gauge).

- Total duct leakage test, total leakage (attic hatch closed, 10 second average, and calibrated gauge).

\section{Testing Modifications}

Though the air infiltration test and the duct leakage test were fairly standard, the standard test procedure was modified to ensure accuracy and repeatability.

The modifications to the standard air infiltration test included:

- Baseline pressure adjustment on the blower door test was used. A 1-minute baseline house pressure was measured (and recorded) and entered into the manometer that adjusts the house pressure for the pretest house pressure. This ensures that the house is measured 
at 50 Pascals and the 50 Pascal test pressure is not influenced by wind or stack-effect pressures or mechanical driven pressures caused by the HVAC system.

- Cruise control was used to hold the test pressure constant. In addition to the mathematical correction performed by the monometer to correct the house test pressure to 50 Pascals, the "Cruise" function was used on the speed controller to hold the house pressure at 50 Pascals.

- One-minute test duration was used. To average out any transients caused by wind a 1minute blower door test was performed. The manometer was set for "long-term average" and a timer was used to ensure a test length of 1 minute.

- Posttest baseline test. A 1-minute house posttest baseline pressure was measured and recorded to ensure that no HVAC fans turned on during the 3-minute infiltration test period.

- All manometers were factory calibrated before this testing effort began.

The modifications to the standard duct leakage to the outside test included:

- House pressure was held constant at 25 Pascals using the "cruise" function on the blower door fan while the ducts were being pressurized for the leakage test to the outside.

- $\quad$ The Duct Blaster reading was taken using a 10-second average reading.

- Since leakage to the outside can be very small a Duct Blaster "Ring 4" was used for these measurements. A Ring 4 can measure leakage down to $2.4 \mathrm{CFM}$.

- All manometers were factory calibrated before this testing effort began.

\section{Results}

Results from the testing of the 20 Meritage homes is presented in Table 25 through Table 27, with Table 25 showing results with the attic hatch closed, Table 26 with attic hatch open (and compared to HERS test result), and Table 27 the duct leakage results. The red shaded entries represent the prior HERS readings completed at the houses, which are in generally good alignment with the independent testing results. Overall the houses are very tight with an average ACH50 of 2.01 (Table 2), including house \#4 (which had a sizable penetration introduced by the PV installer that was later corrected). On average, $36 \%$ of the total house leakage was attributed to the attic space (33\%, excluding house \#4).

The overall mean enclosure leakage of this sample, at $2.01 \mathrm{ACH} 50$ (1.88 median ACH50), is nearly $60 \%$ lower than the most recent broad new home testing sample which demonstrated a median leakage rate of 4.66 ACH50 (2010 testing sample presented in PIER report 500-2012062 entitled Efficiency Characteristics and Opportunities for New California Homes). On average, the testing presented in Table 2 generated nearly identical average leakage as documented by the HERS rater, although there were some site-to-site differences averaging $8 \%$. The current 20-home sample also demonstrated much less variation in air leakage (1.52 ACH50 to $2.7 \mathrm{ACH} 50$, a variation of $1.8 \mathrm{x}$, not counting the single outlier) as opposed to the 2010 research sample (varied from 2.8 $\mathrm{ACH} 50$ to $8.1 \mathrm{ACH} \mathrm{50,} \mathrm{a} \mathrm{variation} \mathrm{of} \mathrm{2.9x,} \mathrm{excluding} \mathrm{outliers).}$ 
Table 25. Whole-House and Attic Infiltration (with attic hatch closed)

\begin{tabular}{|c|c|c|c|c|}
\hline \multirow[b]{2}{*}{ House ID } & \multicolumn{4}{|c|}{ Test 1: Infiltration (w/hatch closed) } \\
\hline & Floor Area & Stories & Infiltration (CFM50) & $\mathrm{ACH} 50$ \\
\hline 1 & 2347 & 1 & 538 & 1.53 \\
\hline 2 & 2630 & 2 & 742 & 1.88 \\
\hline 3 & 3085 & 2 & 701 & 1.51 \\
\hline 4 & 2278 & 1 & 1026 & 3.00 \\
\hline 5 & 3085 & 2 & 974 & 2.10 \\
\hline 6 & 3439 & 2 & 998 & 1.93 \\
\hline 7 & 2502 & 2 & 781 & 2.08 \\
\hline 8 & 2248 & 2 & 742 & 2.20 \\
\hline 9 & 2386 & 2 & 951 & 2.66 \\
\hline 10 & 2004 & 2 & 777 & 2.58 \\
\hline 11 & 3046 & 1 & 936 & 2.05 \\
\hline 12 & 3085 & 2 & 677 & 1.46 \\
\hline 13 & 3085 & 2 & 775 & 1.67 \\
\hline 14 & 3806 & 2 & 1030 & 1.71 \\
\hline 15 & 3806 & 2 & 968 & 1.61 \\
\hline 16 & 2347 & 1 & 887 & 2.52 \\
\hline 17 & 2347 & 1 & 543 & 1.54 \\
\hline 18 & 2670 & 1 & 628 & 1.57 \\
\hline 19 & 2169 & 1 & 602 & 1.85 \\
\hline 20 & 2347 & 1 & 588 & 1.67 \\
\hline Average & 2736 & 1.60 & 793 & 1.96 \\
\hline
\end{tabular}


Table 26. Whole-House and Attic Infiltration (with attic hatch open)

\begin{tabular}{|c|c|c|c|c|c|}
\hline \multirow[b]{2}{*}{ House ID } & \multicolumn{4}{|c|}{ Test 2: Infiltration (w/hatch open) } & \multirow[b]{2}{*}{$\%$ Attic Leakage of Total } \\
\hline & Infiltration (CFM50) & HERS CF-4R (CFM50) & $\mathrm{ACH} 50$ & Attic Infiltration (CFM50) & \\
\hline 1 & 553 & 653 & 1.57 & 198 & $36 \%$ \\
\hline 2 & 751 & 799 & 1.90 & 283 & $38 \%$ \\
\hline 3 & 704 & 627 & 1.52 & 185 & $26 \%$ \\
\hline 4 & 1201 & 1187 & 3.51 & 939 & $78 \%$ \\
\hline 5 & 1007 & 1091 & 2.18 & 309 & $31 \%$ \\
\hline 6 & 1015 & 1034 & 1.97 & 329 & $32 \%$ \\
\hline 7 & 792 & 785 & 2.11 & 168 & $21 \%$ \\
\hline 8 & 757 & 730 & 2.24 & 245 & $32 \%$ \\
\hline 9 & 968 & 964 & 2.70 & 258 & $27 \%$ \\
\hline 10 & 799 & 779 & 2.66 & 304 & $38 \%$ \\
\hline 11 & 981 & 1060 & 2.15 & 591 & $60 \%$ \\
\hline 12 & 683 & 730 & 1.48 & 191 & $28 \%$ \\
\hline 13 & 778 & 680 & 1.68 & 246 & $32 \%$ \\
\hline 14 & 1033 & 1053 & 1.71 & 241 & $23 \%$ \\
\hline 15 & 970 & 920 & 1.61 & 247 & $26 \%$ \\
\hline 16 & 905 & 692 & 2.57 & 464 & $52 \%$ \\
\hline 17 & 545 & 596 & 1.55 & 171 & $31 \%$ \\
\hline 18 & 629 & 711 & 1.57 & 215 & $34 \%$ \\
\hline 19 & 604 & 518 & 1.86 & 219 & $36 \%$ \\
\hline 20 & 590 & 693 & 1.68 & 196 & $33 \%$ \\
\hline Average & 813 & 815 & 2.01 & 300 & $36 \%$ \\
\hline
\end{tabular}

Duct leakage to the outside, whether measured with the attic hatch open or closed, was small; $0.7 \%$ measured with the hatch open, and $1.3 \%$ measured with the hatch closed. Total duct leakage was higher than expected at $8.1 \%$ compared to the 2010 PIER research sample at 5\%, possibly due to HVAC contractors being less vigilant with the conditioned attic. In all houses except site 4, the DLO measurement was within 10 CFM of the HERS reported value. (House 4 has the penetration from the photovoltaics installer, which likely explains the difference.) 
Table 27. Total Duct Leakage and DLO Results

\begin{tabular}{|c|c|c|c|c|c|c|c|}
\hline House ID & $\begin{array}{c}\text { AC } \\
\text { sizing } \\
\text { tons }\end{array}$ & $\begin{array}{c}\text { AC } \\
\text { sizing } \\
\text { ft2/ton }\end{array}$ & $\begin{array}{r}\text { Leakage to O } \\
\text { (w/hatch open) }\end{array}$ & $\begin{array}{l}\text { est 3: Duct Leakag } \\
\text { utside (CFM25) } \\
\text { (w/hatch closed) }\end{array}$ & HERS CF-4R (CFM25) & Total Duct Lkg & \% Leakage \\
\hline 1 & 3.0 & 782 & 5.9 & 18.3 & 11 & 67 & $5.6 \%$ \\
\hline 2 & 3.5 & 751 & 7.2 & 21.0 & 15 & 104 & $7.4 \%$ \\
\hline 3 & 3.5 & 881 & 7.1 & 13.0 & 15 & 109 & $7.8 \%$ \\
\hline 4 & 3.5 & 651 & 8.3 & 26.0 & 11 & 81 & $5.8 \%$ \\
\hline 5 & 3.5 & 881 & 4.2 & 11.9 & 8 & 77 & $5.5 \%$ \\
\hline 6 & 4.0 & 860 & 2.5 & 8.8 & 17 & 150 & $9.4 \%$ \\
\hline 7 & 3.5 & 715 & 4.2 & 11.3 & 10 & 107 & $7.6 \%$ \\
\hline 8 & 3.0 & 749 & 8.4 & 16.8 & 14 & 59 & $4.9 \%$ \\
\hline 9 & 3.0 & 795 & 5.6 & 17.5 & 17 & 149 & $12.4 \%$ \\
\hline 10 & 3.0 & 668 & 7.6 & 18.6 & 12 & 66 & $5.5 \%$ \\
\hline 11 & 3.5 & 870 & 8.9 & 17.1 & 9 & 80 & $5.7 \%$ \\
\hline 12 & 3.5 & 881 & 6.5 & 22.6 & 13 & 156 & $11.1 \%$ \\
\hline 13 & 3.5 & 881 & 12.1 & 19.0 & 17 & 101 & $7.2 \%$ \\
\hline 14 & 4.0 & 952 & 9.9 & 13.0 & 11 & 82 & $5.1 \%$ \\
\hline 15 & 4.0 & 952 & 11.0 & 21.0 & 14 & 169 & $10.6 \%$ \\
\hline 16 & 3.5 & 671 & 9.8 & 19.6 & 12 & 113 & $8.1 \%$ \\
\hline 17 & 3.0 & 782 & 19.2 & 21.0 & 23 & 150 & $12.5 \%$ \\
\hline 18 & 3.0 & 890 & 8.6 & 13.0 & 10 & 130 & $10.8 \%$ \\
\hline 19 & 3.0 & 723 & 10.2 & 11.0 & 10 & 100 & $8.3 \%$ \\
\hline 20 & 3.0 & 782 & 20.0 & 23.0 & 17 & 120 & $10.0 \%$ \\
\hline Average & 3.4 & 806 & 8.9 & 17.2 & 13 & 109 & $8.1 \%$ \\
\hline
\end{tabular}

\section{Testing Recommendations}

With the increasing variety and complexity of home ventilation strategies a pre- and postbaseline pressure measurement should be taken and recorded for all infiltration testing - not just cathedralized attic homes. A high pretest baseline pressure will enable the test technician to identify and shutoff ventilation fans in the home. A difference between the pretest and posttest baseline pressures will indicate if an automatic fan (humidistat, occupancy, or timer) turned on or off during the test.

- Require that pre and post baseline house pressures be recorded.

Total duct leakage should always be measured and be below $6 \%$, even when ducts are located in conditioned space. A total duct leakage test will:

- Catch any catastrophic blunders such as a completely disconnected duct.

- Ensure that excessive duct leakage does not overheat or overcool the attic.

- Ensure the full air flow and delivery velocity is actually delivered to the rooms.

Currently information provided by the testing equipment manufacturer contradicts the HERS providership or simply lacks guidance. The test equipment manufacturer says to open interior partition doors (such as an attic hatch in a cathedralized attic home), yet some HERS providerships say to test the home as found (hatch closed). Title 24 needs to provide guidance on this topic. 


\section{Appendix D: Field Data Results}

The following data capture all diagnostic testing completed at both the base case and advanced test houses. Sites are list as "B-\#" for base case or "A-\#" for advanced, with site numbering corresponding to the identifiers listed in the body of the report. Thermal duct testing data are reported as simultaneous temperature readings at the duct collar at the supply plenum and the center of the downstream supply register. In the example below, the Bedroom 3 entry shows a $57.6^{\circ} \mathrm{F}$ supply duct entry temperature and a $63.8^{\circ} \mathrm{F}$ supply register temperature for Test \#1.

Start Time

Outside Temperature

Attic Temperature

Bedroom 3

\begin{tabular}{ll} 
Test 1 & Test 2 \\
\hline $3: 51 \mathrm{PM}$ & $3: 57 \mathrm{PM}$ \\
$94.8^{\circ} \mathrm{F}$ & 94.9 \\
103.1 & 102.9
\end{tabular}

$57.6-63.8$

$56.9-63.5$
Air Flow

133 CFM 
Site B-2, Vacaville, CA Lot 447, Plan 2400, Summer Duct Performance Testing (Base Case) Tested By: Rick Chitwood and Matt Seitzler

July $25^{\text {th }}, 2014$

Duct Temperature Gain and Grille Air Flows:

- Air conditioner ran 29 minutes (3:41 start time) before testing started

- Tile roof with radiant barrier roof sheathing

\begin{tabular}{llll} 
& Temperature Test 1 & Temperature Test 2 & Air Flow (both calling) \\
\hline Attic Temperature & $113.0^{\circ} \mathrm{F}$ & 112.3 & \\
Outside Temperature & 97.5 & 99.7 \\
Return Grille & 77.4 & 76.5 \\
Time & $4: 10 \mathrm{PM}$ & $4: 18$
\end{tabular}

$1^{\text {st }}$ Floor Supplies:

1. Living Room

$56.9-62.5$

$56.2-61.9$

59 CFM

2. Dining Room

$56.9-60.9$

$56.1-60.6$

59 CFM

3. Powder Room

$56.9-61.3$

$56.1-61.1$

23 CFM

4. Kitchen

$56.8-59.4$

$56.0-59.2$

105 CFM

5. Nook

$56.9-57.9$

$56.0-57.6$

139 CFM

6. Family Room

$56.9-58.9$

$55.9-58.5$

188 CFM

$2^{\text {nd }}$ Floor Supplies:

1. Loft

2. Master Bedroom

3. Master Bathroom

4. Laundry

5. Bathroom 2

6. Bedroom 2

7. Bedroom 3

8. Bedroom 4

Time

Return Grille

Outside Temperature

Attic Temperature

Total Test Time

Sum of the supply grille air flow

Zonal Air Flows

$1^{\text {st }}$ Floor Supplies:

7. Living Room

8. Dining Room

9. Powder Room

10. Kitchen

11. Nook

12. Family Room

$2^{\text {nd }}$ Floor Supplies:

9. Loft

10. Master Bedroom
$54.8-57.5$

$54.9-56.5$

$54.8-57.5$

$54.9-56.9$

$54.8-57.5$

$54.7-59.0$

$54.8-58.1$

$54.9-57.3$

4:17

76.5

99.7

112.3

7 minutes

Down-Only Calling

102 CFM
104 CFM
39 CFM
185 CFM
249 CFM
315 CFM

315 CFM

116 CFM

141 CFM

$54.8-57.1$

4:25

76.1

98.8

114.5

6 minutes
59 CFM
59 CFM
23 CFM
105 CFM
139 CFM
188 CFM

116 CFM

141 CFM

69 CFM

30 CFM

$22 \mathrm{CFM}$

64 CFM

108 CFM

50 CFM

1,173 CFM

Both Calling

Up-Only Calling

$\begin{array}{ll}116 \mathrm{CFM} & 198 \mathrm{CFM} \\ 141 \mathrm{CFM} & 247 \mathrm{CFM}\end{array}$

198 CFM

247 CFM 
11. Master Bathroom

12. Laundry

13. Bathroom 2

14. Bedroom 2

15. Bedroom 3

16. Bedroom 4

System Totals:

$\underline{\text { Static Pressure: }}$

Fan W:

Return Grille Air Flow (cooling):

\section{Duct Leakage:}

Total Duct Leakage $\quad 69 \mathrm{CFM}_{25}$ DLO $46 \mathrm{CFM}_{25}$

House Leakage: $\quad 1,809 \mathrm{CFM}_{50}$
994 CFM

1.07 in.

$-159.2 \mathrm{~Pa},+110.3 \mathrm{~Pa}$
69 CFM

30 CFM

$22 \mathrm{CFM}$

$64 \mathrm{CFM}$

$108 \mathrm{CFM}$

$50 \mathrm{CFM}$

122 CFM

59 CFM

$51 \mathrm{CFM}$

113 CFM

191 CFM

84 CFM

1,065 CFM

1,173 CFM

0.99 in.

1.07 in.

$-181.1 \mathrm{~Pa},+65.6 \mathrm{~Pa} \quad-159.4 \mathrm{~Pa},+107.7 \mathrm{~Pa}$

$820 \mathrm{~W}$

Both calling, $0.70 \mathrm{~W} / \mathrm{CFM}$

Both calling, TrueFlow
1,167 CFM 
Site B-4, Fresno, CA, Lot 40, Plan 1622, Summer Duct Performance Testing (Base Case) Tested By: Rick Chitwood

June 19, 2014

\section{Duct Temperature Gain and Supply Grille Air Flows}

- Air conditioner run for 20 minutes before measurements were started (3:31 PM - 3:51 PM)

Start Time

Outside Temperature

Attic Temperature

Return Duct

Bedroom 3

Bedroom 2

Great Room

Master Bedroom

Master Bathroom

Return Duct

Attic

Outside

End Time

Total Time

Sum of the Supplies

\begin{tabular}{llr} 
Test 1 & Test 2 & Air Flow \\
\hline $3: 51 \mathrm{PM}$ & $3: 57 \mathrm{PM}$ & \\
$94.8^{\circ} \mathrm{F}$ & 94.9 & \\
103.1 & 102.9 & \\
$76.2-76.5$ & $75.9-76.2$ & 133 CFM \\
$57.6-63.8$ & $56.9-63.5$ & 72 CFM \\
$57.5-62.6$ & $57.1-62.3$ & 282 CFM \\
$57.1-61.5$ & $56.8-61.3$ & 200 CFM \\
$55.9-56.6$ & $55.9-56.5$ & 64 CFM \\
$54.8-55.2$ & $54.1-54.9$ & \\
$76.0-76.2$ & $75.7-76.1$ & \\
102.9 & 102.0 & \\
94.9 & 96.1 & \\
$3: 57$ PM & $4: 02$ PM & \\
6 minutes & 5 minutes &
\end{tabular}

$751 \mathrm{CFM}$

Fan W: $\quad 229 \mathrm{~W}$ (cooling, standby W 6.2 W, $0.30 \mathrm{~W} / \mathrm{CFM})$

Static Pressure: $\quad 0.538$ in. $(-83.8 \mathrm{~Pa},+50.7 \mathrm{~Pa})$

Return Grille Air Flow: 762 CFM (cooling, using true flow, 376 CFM/ton, 2 ton condensing unit) 
Site B-4, Fresno, CA, Lot 40, Plan 1622, Winter Duct Performance Testing (Base Case) Tested By: Rick Chitwood

January 15, 2014

\section{Duct Temperature Loss and Supply Grille Air Flows}

- Furnace ran for 10 minutes before testing started.

- All measurements below were taken in 8 minutes.

- Could not measure return duct loss since the return grille entering air fluctuated 2 degrees due to room to air currents.

Master Bathroom Supply:

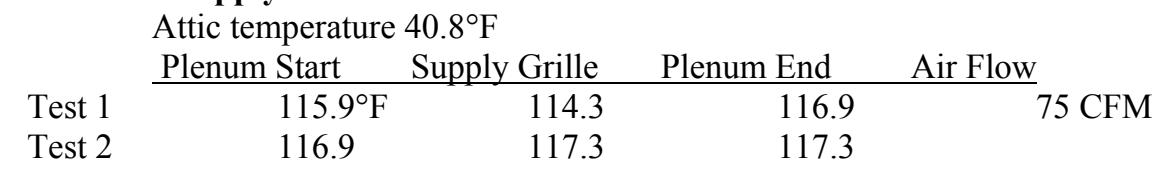

Master Bedroom Supply:

Attic temperature 41.2

$\begin{array}{lllll}\text { Test } 1 & 143.9 & 135.5 & 144.3 & 228 \\ \text { Test } 2 & 144.3 & 135.4 & 144.0 & \end{array}$

Living Room, Bedroom 2 and Bedroom 3 Supply:

Attic Temperature 41.7

$\begin{array}{lllllr}\text { Test 1 } & 143.5 & \text { Living } & 137.1 & & 326 \\ \text { Test 1 } & & \text { Bed 2 } & 135.5 & & 83 \\ \text { Test 1 } & & \text { Bed 3 } & 131.8 & 144.2 & \underline{150} \\ & & & & & 862 \\ \text { Test 2 } & 144.2 & \text { Living } & 138.3 & & \\ \text { Test 2 } & & \text { Bed 2 } & 136.6 & & \\ \text { Test 2 } & & \text { Bed 3 } & 132.8 & 144.9 & \end{array}$

Fan W:

$378 \mathrm{~W}$ (total wattage with burner on)

Static Pressure:

0.661 in. $(-88.0 \mathrm{~Pa},+77.2 \mathrm{~Pa},+40.6 \mathrm{~Pa}$ in supply plenum)

Return Grille Air Flow:

Using TrueFlow $\quad 865$ CFM

Using Duct Blaster $\quad 854$ CFM

Duct Leakage and Half Nelson:
Total Duct Leakage
DLO
$21 \mathrm{CFM}_{25}$
Half Nelson
$35 \mathrm{CFM}_{25}$
$-170.4 \mathrm{~Pa},+206.4 \mathrm{~Pa}$

House Leakage: $929 \mathrm{CFM}_{50}$ 
Site B-5, Sanger, CA, Plan 1950, Lot 127, Summer Duct Performance Testing (Base Case) Tested By: Rick Chitwood

June 17, 2014

\section{Grille Air Flows and Duct Temperature Gain:}

- The two supply ducts in the sales office (garage) were sealed for all testing.

- $3 \frac{1}{2}$ ton outdoor unit, sized 557 sq. ft. per ton.

- The attic temperatures were low on this sunny day mostly because of radiant barrier roof sheathing and tile roofing.

- The air conditioner was run for 19 minutes before starting testing (4:43 PM to 5:02 PM)

- This HVAC system includes a 12-in. by-pass duct between the supply plenum and return plenum with a barometric damper. By-pass ducts have a negative impact on system performance. This by-pass duct did not hurt system performance as much as it could have because the barometric damper weighted arm could only move about 2 inches before it hit a truss web - preventing it from by-passing too much conditioned air.

\begin{tabular}{|c|c|c|c|}
\hline Test1 & Tes & \multicolumn{2}{|c|}{ Air Flow (both calling) } \\
\hline Start time & 5:02 PM & $5: 14$ & \\
\hline Attic Temperature & $103.5^{\circ} \mathrm{F}$ & 102.5 & \\
\hline Outside Temperature & $82.7^{\circ} \mathrm{F}$ & 80.8 & \\
\hline Return Duct & $73.3-73.3$ & $72.2-72.5$ & \\
\hline \multicolumn{4}{|l|}{$1^{\text {st }}$ Floor Supplies: } \\
\hline 1. Entry & $51.7-54.1$ & $51.1-53.2$ & $134 \mathrm{CFM}$ \\
\hline 2. Bedroom 5 & $51.7-54.9$ & $51.1-54.1$ & $123 \mathrm{CFM}$ \\
\hline 3. $1^{\text {st }}$ Floor Bath & $51.7-54.9$ & $51.2-54.1$ & $45 \mathrm{CFM}$ \\
\hline 4. Living & $51.7-54.8$ & $51.1-53.9$ & $93 \mathrm{CFM}$ \\
\hline 5. Dining & $51.6-55.3$ & $51.0-54.7$ & 87 CFM \\
\hline 6. Kitchen & $51.6-56.1$ & $50.9-55.3$ & $80 \mathrm{CFM}$ \\
\hline \multicolumn{4}{|l|}{$2^{\text {nd }}$ Floor Supplies: } \\
\hline 1. Master Toilet Room & $48.9-53.1$ & $48.5-52.5$ & 47 CFM \\
\hline \multicolumn{2}{|c|}{ 2. Master Bathroom $49.0-54.5$} & $48.5-53.8$ & $61 \mathrm{CFM}$ \\
\hline 3. Master Bedroom & $48.9-52.4$ & $48.5-52.0$ & 97 CFM \\
\hline 4. Master Closet & $48.9-51.5$ & $48.4-51.1$ & $48 \mathrm{CFM}$ \\
\hline 5. Laundry Room & $48.9-52.4$ & $48.4-52.2$ & $54 \mathrm{CFM}$ \\
\hline 6. Bedroom 4 & $48.9-52.5$ & $48.4-51.7$ & $128 \mathrm{CFM}$ \\
\hline 7. Bedroom 3 & $48.9-54.5$ & $48.3-54.2$ & $68 \mathrm{CFM}$ \\
\hline 8. Bedroom 2 & $48.9-55.5$ & $48.4-55.0$ & $85 \mathrm{CFM}$ \\
\hline 9. Hall Bath & $48.7-53.1$ & $48.3-52.6$ & $31 \mathrm{CFM}$ \\
\hline Return Duct & $72.2-72.7$ & $71.2-72.0$ & \\
\hline Outside Temperature & 80.8 & 81.5 & \\
\hline Ending Attic Temperature & 102.9 & 101.2 & \\
\hline Ending Time & $5: 12$ & $5: 25$ & \\
\hline Total Testing Time & 10 minutes & 11 minutes & \\
\hline
\end{tabular}

Sum of the supply grille air flow 


\section{Zonal Air Flows - Cooling}

$1^{\text {st }}$ Floor Supplies:

13. Entry

14. Bed 5

15. $1^{\text {st }}$ Floor Bath

16. Living

17. Dining Room

18. Kitchen
Down-Only Calling

232 CFM

206 CFM

$82 \mathrm{CFM}$

157 CFM

162 CFM

144 CFM
Both Calling

134 CFM

123 CFM

45 CFM

93 CFM

87 CFM

80 CFM

47 CFM

61 CFM

97 CFM

48 CFM

54 CFM

128 CFM

68 CFM

85 CFM

$31 \mathrm{CFM}$

\section{1,181 CFM}

$337 \mathrm{CFM} /$ ton

$582 \mathrm{~W}$

$0.50 \mathrm{~W} / \mathrm{CFM}$

0.65 in.
0.77 in.

$596 \mathrm{~W}$

$0.62 \mathrm{~W} / \mathrm{CFM}$

Static Pressure:

Return Grille Air Flow: (True Flow)
Up-Only Calling

0 CFM

0 CFM

0 CFM

0 CFM

0 CFM

0 CFM

83 CFM

107 CFM

152 CFM

78 CFM

83 CFM

194 CFM

127 CFM

152 CFM

54 CFM

$1,030 \mathrm{CFM}$

$294 \mathrm{CFM} / \mathrm{ton}$

$0.56 \mathrm{~W} / \mathrm{CFM}$

0.73 in.

1,209 CFM

Duct Leakage and Half Nelson:

Total Duct Leakage

DLO

Half Nelson

$93 \mathrm{CFM}_{25}$

$76 \mathrm{CFM}_{25}$

$-253.0 \mathrm{~Pa},+30.7 \mathrm{~Pa}$

\section{House Leakage:}

$1,556 \mathrm{CFM}_{50}\left(5.6 \mathrm{ACH}_{50}\right)$ 
Site B-6, Sacramento, CA, Lot 3, Summer Duct Performance Testing (Base Case)

Tested By: Rick Chitwood and Joshua McNeil

July 10, 2014

Duct Temperature Gain and Grille Air Flows:

- The air conditioner ran for 34 minutes before testing started.

\begin{tabular}{llll} 
& Test1 & Test 2 & Air Flow \\
\hline System Start Time & $1: 10 \mathrm{PM}$ & & \\
Outside Temperature & $85.7^{\circ} \mathrm{F}$ & 84.4 & \\
Attic Temperature & 99.1 & 99.7 & \\
Return Duct Temperature & $75.6-75.9$ & $15.5-75.9$ & \\
Start Time & $1: 44$ & & 58 CFM \\
& & $55.1-56.4$ & 35 CFM \\
Master Closet & $55.1-56.5$ & $53.3-58.6$ & 32 CFM \\
Master Bedroom & $53.7-59.0$ & $55.1-58.0$ & 32 CFM \\
Master Bath & $55.5-58.6$ & $55.1-59.9$ & 195 CFM \\
Hall Bath & $55.6-60.3$ & $54.4-56.7$ & 173 CFM \\
Bedroom 2 (M. Bed Side) & $54.6-57.1$ & & \\
Bedroom 3 (M. Closet side) & $54.7-58.1$ & $54.3-57.1$ & 188 CFM \\
& & $54.5-57.1$ & 176 CFM \\
Entry & $54.4-58.0$ & $53.5-59.2$ & \\
Dining & $54.3-57.1$ & & \\
Kitchen & $53.9-59.1$ & $1: 59$ & \\
& & $74.4-75.2$ & \\
Finish Time & $1: 51$ & 99.6 & \\
Return Duct Temperature & $75.5-76.3$ & 83.5 & \\
Attic Temperature & 99.1 & 7 minutes & \\
Outside Temperature & 84.4 & & \\
Total Test Time & 7 minutes & & \\
Sum of the supply grille air flow & & &
\end{tabular}

Fan W:

$536 \mathrm{~W}(0.478 \mathrm{~W}$ per CFM)

Static Pressure:

0.456 in. $(-80.8 \mathrm{~Pa},+33.2 \mathrm{~Pa})$

Return Grille Air Flow (True Flow)

$1,122 \mathrm{CFM}$

Duct Leakage and Half Nelson:

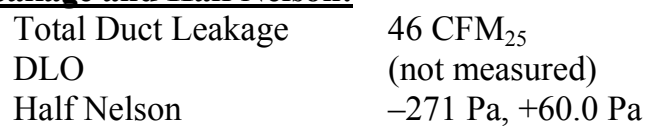

House Leakage: $\quad$ (not measured, no balcony door weather stripping or permanent attic access hatch) 
Site B-7, Sacramento, CA, Lot 27, Winter Duct Performance Testing (Base Case) Tested By: Rick Chitwood and Allen Amaro

January 21, 2014

\section{Duct Temperature Loss and Grille Air Flows:}

- Furnace ran for 14 minutes before testing started.

- All temperature measurements below were taken in 11 minutes.

\begin{tabular}{lllr} 
& Test1 & Test 2 & Air Flow \\
\hline Attic Temperature & $44.3^{\circ} \mathrm{F}$ & 44.7 & \\
Return Duct & $66.5-66.4$ & $67.3-67.1$ & 947 CFM \\
$2^{\text {nd }}$ Floor Supplies: & & & \\
Master Closet & $92.5-82.5$ & $90.5-83.1$ & 66 CFM \\
Master Bedroom & $91.9-84.9$ & $90.3-85.9$ & 165 CFM \\
Master Bath & $91.3-85.8$ & $90.1-86.6$ & 48 CFM \\
Bedroom 2 (track side) & $91.7-84.1$ & $91.3-84.1$ & 136 CFM \\
Bedroom 3 & $90.1-84.3$ & $88.3-84.9$ & 154 CFM \\
Hall Bath & $94.1-86.6$ & $91.9-87.7$ & 40 CFM \\
$1^{\text {st Floor Supplies: }}$ & & & \\
Entry & $93.2-82.8$ & $92.4-83.3$ & 120 CFM \\
Dining & $88.3-86.1$ & $88.7-85.9$ & 114 CFM \\
Kitchen & $88.4-83.2$ & $88.3-83.8$ & 110 CFM \\
Ending Attic Temperature & & 44.7 & \\
$3^{\text {rd }}$ Return Duct Test & $67.3-66.9$ & & \\
Supply and Return Water & $133.1-92.1^{\circ} \mathrm{F}$ & $132.7-91.9$ & \\
Sum of the supply grille air flow & & & 953 CFM
\end{tabular}

Fan W:

$553 \mathrm{~W}$ (combined hydronic AHU, Aspen ABM364-000+WT3SP)

\section{Static Pressure:}

0.455 in. $(-77.0 \mathrm{~Pa},+35.4 \mathrm{~Pa}$, has a 1-in. minimum efficiency filter installed in a 2-in. filter space)

Return Grille Air Flow (heating):

$\begin{array}{ll}\text { Using TrueFlow } & 934 \mathrm{CFM} \\ \text { Using Duct Blaster } & 947 \mathrm{CFM}\end{array}$

\section{Duct Leakage and Half Nelson:}

Total Duct Leakage

$52 \mathrm{CFM}_{25}$ (reported as $86 \mathrm{CFM}_{25}$ by HERS Rater, said 4 ton AC - but is 3 ton) DLO $42 \mathrm{CFM}_{25}$

Half Nelson

$-117.6 \mathrm{~Pa},+224.5 \mathrm{~Pa}$

\section{House Leakage:}

$1,009 \mathrm{CFM}_{50}$ (model home, the sales office is located in the garage with a temporary raised floor, the sales office has a mini-split for heating and cooling) 
Site A-1, Fresno, CA, Lot 24, 1870 Plan, Winter Duct Performance Testing (Advanced Case)

Tested By: Rick Chitwood

February 8, 2014

NWS Fresno Min Outdoor Temp $=51 \mathrm{~F}$

\section{Duct Temperature Loss and Supply Grille Air Flows}

- Ducts in conditioned space

- The ducts are in sealed drywall chases in the attic

- 8 supply grilles on three supply plenum take-offs

- 4 returns; 3 openings in chases and one short duct inside the attic furnace room

- All times listed are from when the furnace was started at about 7:30 AM, Saturday, February $8^{\text {th }}$

- Some measurements show the heat gain where there should be heat loss, this is due to the difficulty in measuring the average temperature of the air entering or leaving a duct or grille.

Return System Test 1: (temperature measurements are return grille to furnace inlet just behind filter)

Start Time 8 minutes

Outdoor temperature $\quad 51.1^{\circ} \mathrm{F}$

Attic temperature 53.4

Master Suite short return chase

Bedroom 2 short return chase

Hall return with 12 -in. duct

Bedroom 3 long return chase

Finish Time

Attic temperature 53.9

Outdoor temperature

12.5 minutes

$75.5-78.9^{\circ} \mathrm{F} \quad 229 \mathrm{CFM}$

$81.8-78.9 \quad 249$ CFM

$78.5-79.1 \quad 52$ CFM (by subtraction, too large for flow hood)

$85.7-79.3 \quad 84 \mathrm{CFM}$

50.7

Return System Test 2: (temperature measurements are return grille to furnace inlet just behind filter)

Start Time

Outdoor temperature

Attic temperature 53.9

Master Suite short return chase

Bedroom 2 short return chase

Hall return with 12 -in. duct

Bedroom 3 long return chase

Finish Time

Attic temperature 54.3

Outdoor temperature
13 minutes

50.7

$77.5-79.6$
$83.5-79.7$
$78.9-79.7$
$86.6-79.9$

229 CFM

249 CFM

52 CFM (by subtraction, too large for flow hood)

18.0 minutes

51.3

Return System Test 3: (this test was done after all the supply measurements were made)

Start Time

Outdoor temperature

Attic temperature 55.9

Master Suite short return chase

Bedroom 2 short return chase

Hall return with 12-in. duct

Bedroom 3 long return chase

Finish Time

Attic temperature 55.2

Outdoor temperature
46.5 minutes

52.7
$80.7-82.3$
229 CFM
$87.1-82.4$
249 CFM
$82.4-85.5$
$91.9-82.5$
52 CFM (by subtraction, too large for flow hood)
84 CFM

52.0 minutes

52.7 
Bedroom 2 Supply Trunk: (only one supply grille on this supply plenum take-off)

Start Time

Outdoor temperature

Attic temperature 54.3

Supply Plenum start

Bedroom 2 supply grille

Supply Plenum finish

Finish Time

Attic temperature 54.3

Outdoor temperature
21.5 minutes

51.7

\begin{tabular}{lll} 
Test 1 & Test 2 & CFM \\
\hline 124.3 & 124.3 & \\
124.3 & 124.3 & 149 CFM \\
124.3 & 124.3 &
\end{tabular}

26.0 minutes

51.6

Master Suite Supply Trunk: (two supply grilles on this supply plenum take-off)

Start Time

Outdoor temperature

Attic temperature 54.5

Supply Plenum start

Master Bedroom supply grille

Master Bathroom supply grille

Supply Plenum finish

Finish Time

Attic temperature 54.3

Outdoor temperature
28.0 minutes

52.1

\begin{tabular}{llr} 
Test 1 & Test 2 & \multicolumn{1}{c}{ CFM } \\
\hline 137.8 & 137.8 & \\
136.6 & 136.7 & 100 CFM \\
134.9 & 135.0 & 25 CFM \\
137.9 & 137.9 &
\end{tabular}

33.5 minutes

51.6

Main Supply Trunk: (serves dining, living, study, hall bath, and bed 2)

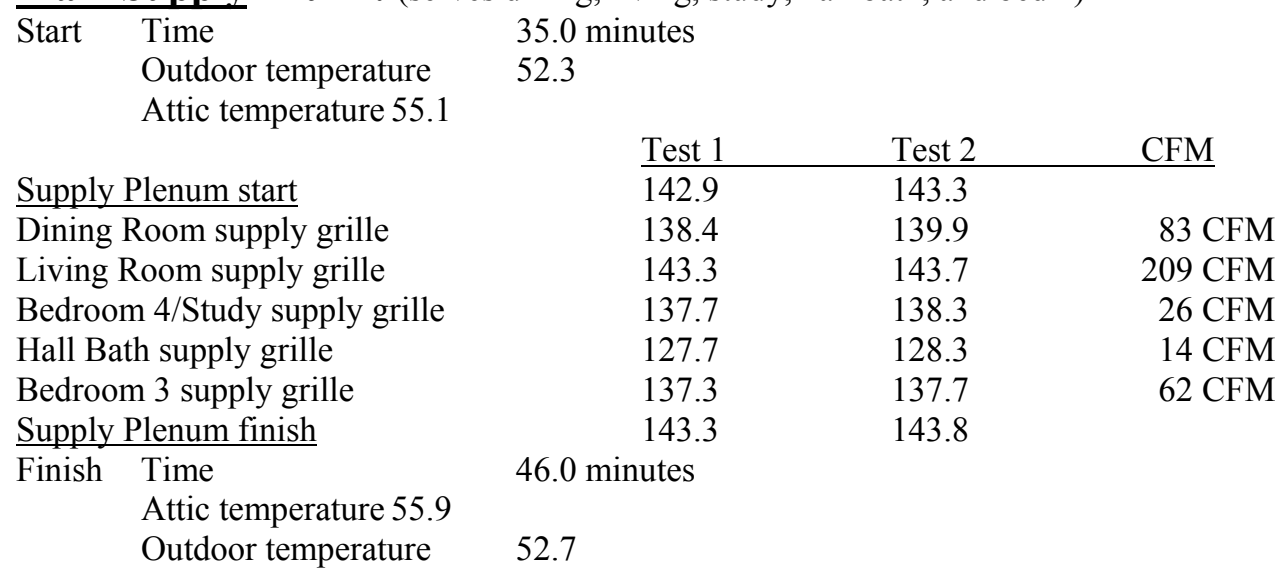

\section{Fan W:}

$191 \mathrm{~W}$ (total wattage with burner on, burner W are $53.5 \mathrm{~W}$ )

Static Pressure:

0.283 in. $(-35.6 \mathrm{~Pa},+35.1 \mathrm{~Pa})$

\section{Return Grille Air Flow:}

Using TrueFlow

Using Duct Blaster

Sum of the supply grilles

Flow from fan curve
607 CFM

614 CFM

668 CFM

637 CFM

Duct Leakage and Half Nelson:

Total Duct Leakage

$23 \mathrm{CFM}_{25}$ 


\section{U.S. DEPARTMENT OF | Energy Efficiency \& \\ Renewable Energy}

DLO

$0 \mathrm{CFM}_{25}$ (too low to measure, below $10 \mathrm{CFM}_{25}$ )

Half Nelson

$-244.9 \mathrm{~Pa},+38.6 \mathrm{~Pa}$

\section{House Leakage:}

$1,331 \mathrm{CFM}_{50}$ (pressure in the attic furnace room with house at $-50 \mathrm{~Pa}$ was $49.6 \mathrm{~Pa}$ ) 
Site A-1, Fresno, CA, Lot 24, 1870 Plan, Summer Duct Performance Testing (Advanced Case)

Tested By: Rick Chitwood

June 18, 2014

Duct Temperature Gain and Supply Grille Air Flows

- This house has a tile roof with radiant barrier roof sheathing which explains the low attic temperatures.

- The supply duct system is in conditioned space and tested zero leakage to the outside, but the return duct chasses and attic mechanical room are part of the return duct system and were not duct tested. The return side duct leakage shows up in the house leakage test. The return duct chase temperature gains are gains to the chases and attic mechanical room.

- Air conditioner ran for 23 minutes before measurements were started (4:16 PM - 4:39 PM).

Start Time

Outside Temperature

Attic Temperature

Master Suite Return Chase

Bedroom 2 Return Chase

Main Return

Bedroom 3 Return Chase

Outside Temperature

Attic Temperature

Time

Bedroom 2

Master Bathroom

Master Bedroom

Dining Room

Living Room

Study

Hall Bathroom

Bedroom 3

End Time

Attic

Outside

Total Time

Sum of the Supplies

\begin{tabular}{llr} 
Test 1 & Test 2 & Air Flow \\
\hline $4: 39$ PM & $4: 58$ PM & \\
$88.6^{\circ} \mathrm{F}$ & 92.0 & \\
98.9 & 99.8 & 344 CFM \\
$75.8-77.7$ & $75.1-77.0$ & 272 CFM \\
$74.3-77.7$ & $73.2-77.0$ & 173 CFM (by subtraction) \\
$76.8-77.6$ & $75.3-77.0$ & 80 CFM \\
$75.3-77.6$ & $75.0-77.0$ & \\
89.3 & 93.4 & \\
98.9 & 100.1 & \\
$4: 44$ PM & $5: 02$ PM & \\
& & 195 CFM \\
$51.3-51.5$ & $50.9-50.9$ & 127 CFM \\
$62.3-62.9$ & $61.4-62.7$ & 108 CFM \\
$62.1-62.3$ & $61.3-61.7$ & 264 CFM \\
$57.6-59.9$ & $57.1-59.6$ & 36 CFM \\
$57.6-57.9$ & $57.1-57.4$ & 19 CFM \\
$57.6-59.2$ & $57.0-58.9$ & 80 CFM \\
$57.5-60.1$ & $57.0-59.7$ & \\
$57.5-59.2$ & $57.0-59.0$ & \\
$4: 56$ PM & $5: 12$ PM & \\
99.8 & 100.5 & \\
92.0 & 92.3 & \\
17 minutes & 14 minutes & \\
& &
\end{tabular}

Fan W: $\quad 272 \mathrm{~W}$ (cooling, standby W $8.2 \mathrm{~W}, 0.31 \mathrm{~W} / \mathrm{CFM})$

Static Pressure: $\quad 0.450$ in.

Return Grille Air Flow: 869 CFM (cooling, using true flow, 435 CFM/ton, 2 ton condensing unit) 
Site A-2, Sacramento, CA, Lot 27, Winter Duct Performance Testing (Advanced Case)

Tested By: Rick Chitwood and Allen Amaro

February 19, 2014

NOTE: A-2 is the same house as Site B-7 (Site was retrofitted to HPA on late January 2014)

Improved (Post Retrofit) Test Data Shown in Red; Original B-7 Data Shown in Black

HPA Improvements Include:

- $\quad$ Replaced all attic duct work with R-8 duct.

- Installed all of the new duct work as low as possible so that it could be buried in the loose fill attic insulation to the extent possible.

- Increased the return duct size from 16 in. to 18 in.

- Shortened the return duct from $22 \mathrm{ft}$ to $9 \mathrm{ft}$.

- Eliminated the return plenum and put a plate and tap-in on the AHU.

Duct Temperature Loss and Grille Air Flows (preretrofit testing completed January 21, 2014):

- Combined hydronic system operated for 14 minutes before testing started.

\begin{tabular}{lllr} 
& Test1 & Test 2 & Air Flow \\
\hline $\begin{array}{l}\text { Attic Temperature } \\
\text { Return Duct }\end{array}$ & $44.3^{\circ} \mathrm{F}$ & 44.7 & \\
$2^{\text {nd }}$ Floor Supplies: & $66.5-66.4$ & $67.3-67.1$ & 947 CFM \\
Master Closet & & & \\
Master Bedroom & $92.5-82.5$ & $90.5-83.1$ & 66 CFM \\
Master Bath & $91.9-84.9$ & $90.3-85.9$ & 165 CFM \\
Bedroom 2 (track side) & $91.3-85.8$ & $90.1-86.6$ & 48 CFM \\
Bedroom 3 & $91.7-84.1$ & $91.3-84.1$ & 136 CFM \\
Hall Bath & $90.1-84.3$ & $88.3-84.9$ & 154 CFM \\
$1^{\text {st Floor Supplies: }}$ & $94.1-86.6$ & $91.9-87.7$ & 40 CFM \\
Entry & & & \\
Dining & $93.2-82.8$ & $92.4-83.3$ & 120 CFM \\
Kitchen & $88.3-86.1$ & $88.7-85.9$ & 114 CFM \\
Ending Attic Temperature & $88.4-83.2$ & $88.3-83.8$ & 110 CFM \\
$3^{\text {rd }}$ Return Duct Test & & 44.7 & \\
Supply and Return Water & $133.1-92.1$ & $67.3-66.9$ & \\
Surt & & $132.7-91.9$ &
\end{tabular}

Sum of the supply grille air flow

Total Testing Time

11 minutes

Duct Temperature Loss and Grille Air Flows (postretrofit testing completed February 19, 2014):

- Combined hydronic system ran for 13 minutes before testing started.

\begin{tabular}{lllr} 
& Test 1 & Test 2 & Air Flow \\
\hline Attic Temperature & $53.8^{\circ} \mathrm{F}$ & 54.7 & \\
Outside Temperature & 50.0 & 51.0 & \\
Return Duct & $69.1-68.9$ & $70.9-70.9$ & 1,142 CFM \\
$2^{\text {nd }}$ Floor Supplies: & & & \\
Master Closet & $93.4-91.3$ & $93.1-92.3$ & 94 CFM \\
Master Bedroom & $95.0-92.3$ & $85.3-84.8$ & 213 CFM \\
Master Bath & $93.7-90.9$ & $89.8-87.3$ & 68 CFM \\
Bedroom 2 (track side) & $94.5-92.1$ & $91.6-89.3$ & 166 CFM \\
Bedroom 3 & $93.0-90.6$ & $85.5-84.4$ & 187 CFM
\end{tabular}


Hall Bath

$1^{\text {st }}$ Floor Supplies:

Entry

Living/Dining

Kitchen

Ending Attic Temperature

$3^{\text {rd }}$ Return Duct Test

Supply and Return Water

Sum of the supply grille air flow

Total Testing Time
$96.9-93.9$

$95.5-90.4$

$93.7-92.9$

$93.6-89.9$

54.7

$134.0-98.3$
$91.4-90.1$

$91.6-88.6$

$92.0-90.3$

$92.1-88.1$

54.9

$70.3-70.4$

$134.1-98.9$

16 minutes
$55 \mathrm{CFM}$

126 CFM

109 CFM

115 CFM

1,133 CFM

\section{Fan W:}

$553 \mathrm{~W}$ (combined hydronic AHU, Aspen ABM364-000+WT3SP, $0.58 \mathrm{~W} / \mathrm{CFM}$ )

$616 \mathrm{~W}$ (pump and controls draw $66.6 \mathrm{~W}, 0.54 \mathrm{~W} / \mathrm{CFM}$ )

\section{Static Pressure:}

0.455 in. $(-77.0 \mathrm{~Pa},+35.4 \mathrm{~Pa}$, has a 1 -in. minimum efficiency filter installed in a 2 -in. filter space)

0.374 in. $(-60.0 \mathrm{~Pa},+33.4 \mathrm{~Pa}$, same filter $)$

\section{Return Grille Air Flow (heating):}

$\begin{array}{ll}\text { Using TrueFlow } & 934 \mathrm{CFM} \\ \text { Using Duct Blaster } & 947 \mathrm{CFM} \\ \text { Using TrueFlow } & 1,137 \mathrm{CFM} \\ \text { Using Duct Blaster } & 1,142 \mathrm{CFM} \text { (21\% increase) }\end{array}$

Duct Leakage and Half Nelson:

Total Duct Leakage

$52 \mathrm{CFM}_{25}$ (reported as $86 \mathrm{CFM}_{25}$ by HERS Rater, said 4 ton $\mathrm{AC}-$ but is 3 ton)

DLO $42 \mathrm{CFM}_{25}$

Half Nelson $\quad-117.6 \mathrm{~Pa},+224.5 \mathrm{~Pa}$

Total Duct Leakage $\quad 35 \mathrm{CFM}_{25}$

DLO $22 \mathrm{CFM}_{25}$

Half Nelson $\quad-282 \mathrm{~Pa},+57.5 \mathrm{~Pa}$

\section{House Leakage:}

$1,009 \mathrm{CFM}_{50}$ (model home, the sales office is located in the garage with a temporary raised floor, the sales office has a mini-split for heating and cooling)

$1,033 \mathrm{CFM}_{50}$ (On the first test we couldn't figure out how to turn off the four bathroom exhaust fans used for indoor air quality so we taped over them. On the second test I figured out how to turn them off and tested with

them off - but not taped. The envelope is tighter now but it doesn't look that way due to change in testing method.) 
Site A-2, Sacramento, CA, Lot 27, Summer Duct Performance Testing (Advanced Case) Tested By: Rick Chitwood and Joshua McNeil

July 10, 2014

Duct Temperature Gain and Grille Air Flows:

- The air conditioner ran for 24 minutes before testing started.

\begin{tabular}{llll} 
& Test1 & Test 2 & Air Flow \\
\hline System Start Time & $3: 29 \mathrm{PM}$ & & \\
Outside Temperature & $87.9^{\circ} \mathrm{F}$ & 89.3 & \\
Attic Temperature & 93.7 & 94.0 & \\
Return Duct Temperature & $76.2-76.3$ & $75.5-75.5$ & \\
Start Time & $3: 53$ & & \\
& & 57.06 & 89 CFM \\
Master Closet & $57.6-57.6$ & $55.9-57.1$ & 66 CFM \\
Master Bedroom & $56.5-57.3$ & $56.6-57.4$ & 10 CFM \\
Master Bath & $56.7-57.4$ & $56.7-58.6$ & 160 CFM \\
Hall Bath & $57.1-58.9$ & $56.7-57.9$ & \\
Bedroom 2 (M. Bed Side) & $56.5-58.2$ & $56.9-58.4$ & 131 CFM \\
Bedroom 3 (M. Closet side) & $57.5-58.7$ & & 111 CFM \\
& & $55.9-60.1$ & 115 CFM \\
Entry & $55.9-60.3$ & $55.5-56.9$ & \\
Dining & $55.3-56.9$ & $56.1-59.4$ & \\
Kitchen & $56.4-59.7$ & & \\
& & $4: 12$ & \\
Finish Time & $4: 04$ & $74.9-74.8$ & \\
Return Duct Temperature & $75.5-75.5$ & 83.9 & \\
Attic Temperature & 94.0 & 6 minutes & \\
Outside Temperature & 89.3 & & \\
Total Test Time & 11 minutes & & \\
Sum of the supply grille air flow & & & \\
& & &
\end{tabular}

Fan W: $540 \mathrm{~W}(0.486 \mathrm{~W}$ per CFM)

\section{Static Pressure:}

0.449 in. $(-79.1 \mathrm{~Pa},+33.2 \mathrm{~Pa})$ 
Site A-3, El Dorado Hills, CA, Lot 410, Winter Duct Performance Testing (Advanced Case) Tested By: Rick Chitwood and Allen Amaro

February 19 and 20, 2014

Duct Temperature Loss and Grille Air Flows:

- $\quad$ Furnace ran for 18 minutes before testing started

Outside Temperature

Attic Temperature

Main Return Duct

Master Bedroom Return Duct

$\underline{1^{\text {st }} \text { Floor Supplies: }}$

1. Flex

2. Powder Room

3. Bath 4

4. Guest Bed

5. Pocket Office (PO)

6. Nook

7. Kitchen

8. Great Room

9. Dining Room

$2^{\text {nd }}$ Floor Supplies:

1. Bonus Room

2. Master Bedroom Front

3. Master Bedroom Back

4. Master Bath

5. Bathroom 3

6. Bedroom 2

7. Game Room

8. Bedroom 3

9. Bedroom 4

10. Bath 2

Main Return Duct

Master Bedroom Return Duct

Ending Attic Temperature

Total Testing Time

Sum of the supply grille air flow

Zonal Air Flows

$\underline{1^{\text {st }} \text { Floor Supplies: }}$

1. Flex

2. Powder Room

3. Bath 4

4. Guest Bed

5. Pocket Office (PO)

6. Nook

7. Kitchen

8. Great Room
Test1 $42^{\circ} \mathrm{F}(2 / 20 / 14,6: 58 \mathrm{AM})$

66.2

$69.9-69.9$

$67.5-67.6$

$123.5-116.4$

$124.1-100.3$

$117.7-90.3$

$117.8-109.4$

$117.7-105.5$

$125.2-111.3$

$125.3-117.1$

$125.7-120.8$

$125.8-114.6$

$113.3-106.4$

$113.3-107.3$

$135.1-115.7$

$134.6-115.8$

$134.9-110.6$

$134.9-114.5$

$135.5-116.3$

$135.5-115.7$

$135.5-112.2$

$135.5-109.8$

$72.6-72.5$

$69.7-69.8$

69.1

18 minutes Test 2

69.1

$72.6-72.5$

$69.7-69.8$

$127.1-119.5$

$127.1-104.3$

$119.6-93.9$

$119.8-110.9$

$119.8-108.6$

$127.4-113.9$

$127.7-118.9$

$127.7-124.1$

$128.1-116.5$

$115.4-111.1$

$115.5-111.2$

$136.7-117.3$

$136.9-119.9$

$136.9-114.1$

$136.7-116.3$

$136.7-117.9$

$136.9-117.2$

$137.0-114.2$

$137.1-112.1$

$75.0-75.1$

$71.1-71.1$

70.8

28 minutes
Air Flow (both calling)

$131 \mathrm{CFM}$

23 CFM

15 CFM

95 CFM

$80 \mathrm{CFM}$

82 CFM

98 CFM

89 CFM

78 CFM

205 CFM

91 CFM

105 CFM

63 CFM

22 CFM

88 CFM

116 CFM

52 CFM

86 CFM

22 CFM

\section{1,541 CFM}

Down-Only Calling Both Calling

Up-Only Calling

238 CFM

$131 \mathrm{CFM}$

13 CFM

40 CFM

23 CFM

15 CFM

23 CFM

157 CFM

95 CFM

$80 \mathrm{CFM}$

5 CFM estimated

143 CFM

82 CFM

5 CFM estimated

150 CFM

177 CFM

98 CFM

12 CFM

16 CFM

$11 \mathrm{CFM}$

153 CFM
89 CFM
12 CFM

$10 \mathrm{CFM}$ 
9. Dining Room

$1^{\text {st }}$ Floor Totals

$\begin{array}{lll}144 \text { CFM } & 78 \text { CFM } & 5 \text { CFM estimated } \\ 1,225 \text { CFM } & 691 \text { CFM } & 89 \text { CFM }\end{array}$

$\underline{2^{\text {nd }} \text { Floor Supplies: }}$

1. Bonus Room

24 CFM

205 CFM

304 CFM

17 CFM

91 CFM

140 CFM

18 CFM

105 CFM

$161 \mathrm{CFM}$

11 CFM

63 CFM

98 CFM

8 CFM estimated

22 CFM

39 CFM

23 CFM

$88 \mathrm{CFM}$

134 CFM

$21 \mathrm{CFM}$

116 CFM

179 CFM

8 CFM estimated

52 CFM

$80 \mathrm{CFM}$

15 CFM

86 CFM

133 CFM

6 CFM estimated

22 CFM

33 CFM

$2^{\text {nd }}$ Floor Totals

$151 \mathrm{CFM}$

850 CFM

1,301 CFM

System Totals

1,376 CFM

1,541 CFM

1,390 CFM

Fan W:

$855 \mathrm{~W}(0.57 \mathrm{~W} / \mathrm{CFM})$

\section{Static Pressure:}

0.793 in. $(-86.5 \mathrm{~Pa},+111.8 \mathrm{~Pa})$

\section{Return Grilles Air Flow (heating, both zones calling):}

$\begin{array}{ll}\text { Using TrueFlow } & 1,484 \text { CFM } \\ \text { Using Duct Blaster } & 1,500 \text { CFM }\end{array}$

\section{Duct Leakage and Half Nelson:}

Total Duct Leakage $95 \mathrm{CFM}_{25}$ (outdoor air sealed off)

DLO $0 \mathrm{CFM}_{25}$ (attic hatch open, proper test procedure)

DLO $\quad 0 \mathrm{CFM}_{25}$ (attic hatch closed, normal house operating mode)

Half Nelson $\quad-112.6 \mathrm{~Pa},+285.0 \mathrm{~Pa}$

\section{House Leakage:}

$846 \mathrm{CFM}_{50}$ (attic hatch open, normal test procedure)

$824 \mathrm{CFM}_{50}$ (attic hatch closed, normal house operating mode) 
Site A-3, EI Dorado Hills, CA, Lot 410, Summer Duct Performance Testing (Advanced Case)

Tested By: Rick Chitwood and Allen Amaro

June 20, 2014

Duct Temperature Gain and Grille Air Flows:

- Two zone system, tested with both zones calling

- Air conditioner ran for 20 minutes before testing started (3:31 PM to 3:51 PM)

- Attic temperature at system start $(3: 31 \mathrm{PM})-79.9^{\circ} \mathrm{F}$. Attic temperature at end of 47 minute system run time $-78.1^{\circ} \mathrm{F}$

- The measured return duct temperatures went in the wrong direction, by a few tenths of a degree, on all 8 measurements. This is probably due to the difficulty measuring the average entering air temperature on a large return air grille.

\begin{tabular}{l}
\hline Start time \\
Attic Temperature \\
Outside Temperature \\
Main Return Duct \\
Master Bedroom Return Duct \\
$1^{\text {st }}$ Floor Supplies: \\
1. $\quad$ Flex \\
2. Powder Room \\
3. Bath 4 \\
4. Guest Bed \\
5. Pocket Office (PO) \\
6. Nook \\
7. Kitchen \\
8. Great Room \\
9. Dining Room \\
2nd Floor Supplies: \\
10. Bonus Room \\
11. Master Bedroom Front \\
12. Master Bedroom Back \\
13. Master Bath \\
14. Bathroom 3 \\
15. Bedroom 2 \\
16. Game Room \\
17. Bedroom 3 \\
18. Bedroom 4 \\
19. Bath 2 \\
Master Bedroom Return Duct \\
Main Return Duct \\
Outside Temperature \\
Ending Attic Temperature \\
Ending Time \\
Total Testing Time \\
Sum of the supply grille air flow \\
\end{tabular}

Test1

3:51 PM

$78.9^{\circ} \mathrm{F}$

93.9

$72.4-72.3$

$73.6-73.7$

$53.7-58.7$

$54.0-61.5$

$54.7-62.9$

$54.7-59.6$

$54.1-62.0$

$53.8-58.4$

$53.9-58.3$

$54.1-58.0$

$54.1-58.9$

$53.9-55.8$

$54.6-56.9$

$52.5-55.4$

$52.4-55.6$

$52.4-54.9$

$52.4-55.1$

$52.3-54.5$

$52.1-55.6$

$52.2-57.0$

$52.5-57.5$

$73.1-73.0$

$72.5-72.2$

92.4

78.7

4:05

14 minutes
Test 2

4:06

78.7

92.4

$72.4-72.2$

$73.1-72.9$

$54.2-57.7$

160 CFM

$54.3-60.4$

26 CFM

16 CFM

$111 \mathrm{CFM}$

$56.3-59.9$

93 CFM

93 CFM

118 CFM

107 CFM

96 CFM

$54.3-58.3$

228 CFM

$58.5-59.9$

$106 \mathrm{CFM}$

$58.3-61.1$

117 CFM

$71 \mathrm{CFM}$

27 CFM

97 CFM

134 CFM

65 CFM

98 CFM

24 CFM

$52.5-57.7$

$73.1-72.9$

$72.3-71.9$

90.7

78.1

4:18

12 minutes 
\begin{tabular}{l|l} 
u.s. Department of & Energy Efficiency \& \\
Renewable Energy
\end{tabular}

Fan W:

$879 \mathrm{~W}(0.49 \mathrm{~W} / \mathrm{CFM})$

Static Pressure:

0.880 in. $(-93.0 \mathrm{~Pa},+126.9 \mathrm{~Pa})$

Return Grilles Air Flow (cooling, both zones calling, TrueFlow): $\quad$ 1,806 CFM (452 CFM per ton) 
Site A-4, El Dorado Hills, CA, Lot 476, Winter Duct Performance Testing (Advanced Case) Tested By: Rick Chitwood and Allen Amaro

April 22, 2014

\section{Duct Temperature Loss and Supply Grille Air Flows:}

- This is a one story model home with a sales office in the three car garage.

- The HVAC system was not up-sized for the sales office. The home was tested with the sales office zone sealed off.

- The outdoor air supply fan was sealed off for all testing.

- Furnace ran for 14 minutes before testing started

(sales office ducts sealed)

Outside Temperature

Start Attic Temperature

Main Return Duct

Master Bedroom Return Duct

Room Thermostat

1. Dining

2. Great Room

3. Kitchen

4. Nook

5. Pocket Office (PO)

6. Den

7. Master Bedroom

8. Master Bathroom

9. Master Closet

10. Bedroom 2

11. Bathroom 2

12. Bedroom 3

Main Return Duct

Master Bedroom Return Duct

Ending Attic Temperature

Room Thermostat Temp.

Total Testing Time

Sum of the supply grille air flow $\begin{array}{lll}\text { Test1 } & \text { Test } 2 & \text { Air Flow }\end{array}$

$51^{\circ} \mathrm{F}(8: 25 \mathrm{AM}, 0$ minutes, furnace started $)$

$72.3 \quad 77.2$ (at $23 \mathrm{~min}$.)

77.3 (at $14 \mathrm{~min}$.) $\quad 77.6$ (at $23 \mathrm{~min}$.)

75.6 (at $14 \mathrm{~min}$.) $\quad 76.8$ (at $23 \mathrm{~min}$.)

68 (at $0 \mathrm{~min}$. run time) 69 (at $23 \mathrm{~min}$.)

$\begin{array}{rrr}133.3-127.3 & 136.1-132.5 & \text { 89 CFM } \\ 134.9-132.3 & 137.9-135.2 & 205 \text { CFM } \\ 135.3-132.4 & 137.9-135.3 & 98 \text { CFM } \\ 135.9-128.1 & 138.1-132.9 & 136 \text { CFM } \\ 136.9-129.6 & 138.1-135.5 & 51 \text { CFM } \\ 136.4-128.1 & 138.0-132.8 & 76 \text { CFM } \\ 136.1-133.8 & 137.9-135.5 & 148 \text { CFM } \\ 136.5-127.4 & 137.9-127.6 & 33 \text { CFM } \\ 136.9-126.9 & 138.4-133.0 & 33 \text { CFM } \\ 137.1-125.4 & 137.2-134.9 & 68 \text { CFM } \\ 137.1-127.6 & 137.7-133.3 & 49 \text { CFM } \\ 137.3-129.9 & 138.0-131.1 & 108 \text { CFM }\end{array}$

77.6 (at $22 \mathrm{~min}$.)

76.8 (at $22 \mathrm{~min}$.)

79.7 (at $29 \mathrm{~min}$.)

79.1 (at $29 \mathrm{~min}$.)

79.7 (at $29 \mathrm{~min}$.)

70 (at $29 \mathrm{~min}$.)

69 (at $22 \mathrm{~min}$.)

8 minutes

7 minutes

1,094 CFM

\section{Final Temperature Measurements:}

After air flow measurements at each supply grille the furnace was turned off after 81 minutes of total run time.

The outdoor temperature went from $51^{\circ} \mathrm{F}$ to $53^{\circ} \mathrm{F}$ in this 81 minute period.

The room thermostat went from $68^{\circ} \mathrm{F}$ to $73^{\circ} \mathrm{F}$ in this 81 minute period.

The attic temperature went from $72.3^{\circ} \mathrm{F}$ to $88.7^{\circ} \mathrm{F}$ in this 81 minute period.

\section{Fan W:}

$633 \mathrm{~W}(0.61 \mathrm{~W} / \mathrm{CFM}$, heating mode $)$

\section{Static Pressure:}

$$
0.678 \text { in. }(-56.0 \mathrm{~Pa},+113.5 \mathrm{~Pa} \text {, heating mode })
$$


Return Grilles Air Flow (heating):

Using TrueFlow

$1,042 \mathrm{CFM}$

Duct Leakage and Half Nelson:

Total Duct Leakage $\quad 102 \mathrm{CFM}_{25}(8.5 \%$, outdoor air fan inlet sealed off with tape)

DLO $26 \mathrm{CFM}_{25}$ (attic hatch open, proper test procedure)

Half Nelson $-189.0 \mathrm{~Pa},+228.3 \mathrm{~Pa}$

\section{House Leakage:}

$1,657 \mathrm{CFM}_{50}$ (attic hatch open, normal test procedure) 
Site A-4, EI Dorado Hills, CA, Lot 476, Summer Duct Performance Testing (Advanced Case)

Tested By: Rick Chitwood

July 9, 2014

Duct Temperature Gain and Supply Grille Air Flows:

- This is a one story model home with a sales office in the three car garage.

- The HVAC system was not up-sized for the sales office.

- The home was tested with the sales office zone off.

- The air conditioner ran for 26 minutes before testing started

\begin{tabular}{|c|c|c|c|}
\hline & Test1 & Test 2 & Air Flow \\
\hline System Start Time & 4:04 PM & & \\
\hline Outside Temperature & $97.1^{\circ} \mathrm{F}$ & 94.1 & \\
\hline Main Return Grill Temperature & 71.5 & 71.6 & \\
\hline M.Bed Return Grille Temperature & 72.3 & 72.2 & \\
\hline Attic Temperature & 77.3 & 76.8 & \\
\hline Test Start Time & $4: 30$ & $4: 46$ & \\
\hline 1. Dining & $58.3-59.2$ & $57.5-59.1$ & $134 \mathrm{CFM}$ \\
\hline 2. Great Room & $57.9-60.1$ & $57.9-59.6$ & 274 CFM \\
\hline 3. Kitchen & $58.2-58.5$ & $57.8-58.9$ & 129 CFM \\
\hline 4. Nook & $57.8-60.7$ & $57.9-60.5$ & 175 CFM \\
\hline 5. Pocket Office (PO) & $57.9-59.1$ & $57.9-58.9$ & 63 CFM \\
\hline 6. Den & $57.9-59.9$ & $57.8-59.3$ & 104 CFM \\
\hline 7. Master Bedroom & $56.8-58.2$ & $55.9-56.9$ & 192 CFM \\
\hline 8. Master Bathroom & $56.7-59.3$ & $55.8-57.8$ & $38 \mathrm{CFM}$ \\
\hline 9. Master Closet & $56.7-59.6$ & $55.9-58.1$ & 37 CFM \\
\hline 10. Bedroom 2 & $56.4-59.5$ & $55.4-57.9$ & $69 \mathrm{CFM}$ \\
\hline 11. Bathroom 2 & $56.4-60.5$ & $55.5-58.5$ & 54 CFM \\
\hline 12. Bedroom 3 & $56.4-59.5$ & $55.5-57.8$ & $116 \mathrm{CFM}$ \\
\hline Test Finish Time & $4: 40$ & $4: 58$ & \\
\hline Measurement Time & 10 minutes & 12 minutes & \\
\hline Attic Temperature & 76.9 & 76.0 & \\
\hline Main Return Grill Temperature & 71.1 & 71.2 & \\
\hline M.Bed Return Grille Temperature & 72.1 & 71.8 & \\
\hline Outside Temperature & 95.6 & 96.1 & \\
\hline Sum of the supply grille air flow & & & $1,385 \mathrm{CFN}$ \\
\hline
\end{tabular}

Fan W:

$761 \mathrm{~W}(0.54 \mathrm{~W} / \mathrm{CFM})$

Static Pressure:

0.66 in. $(-45.9 \mathrm{~Pa},+119.1 \mathrm{~Pa})$ 
Site A-5, Anderson, CA, Lot 15, Plan 2205, Summer Duct Performance Testing (Advanced Case)

Tested By: Rick Chitwood

June 5, 2014

Duct Temperature Loss and Grille Air Flows:

- The air conditioner ran for 24 minutes before testing started (started at 3:05)

- All temperature measurements were taken in 10 minutes for the first test and 8 minutes for the second

- Roof is dark colored composition shingles and radiant barrier

- Condensing Unit: Luxaire TCJD18S41S3HA

- Furnace: Johnson Controls Unitary Products TM9V040A10MP11CA, 40,000/26,000 input

- Cooling Coil: $\quad$ Johnson Controls Unitary Products MC18A3XC1A

\begin{tabular}{lllr} 
& Test1 & Test 2 & Air Flow \\
\hline Test Start Time & $3: 29 \mathrm{PM}$ & $3: 39$ & \\
Attic/Outside Temperatures & $135.9^{\circ} \mathrm{F} / 101.3$ & $137.6 / 102.7$ & \\
Return Ducts (Back/Front) & $75.5 / 74.8$ & $75.2 / 74.5$ & \\
Hall Bath & $63.1-63.9$ & $63.1-64.2$ & 67 CFM \\
Bedroom 3 (Front) & $63.2-63.7$ & $63.0-63.9$ & 142 CFM \\
Bedroom 2 (Back) & $63.2-63.8$ & $62.9-63.8$ & 139 CFM \\
Great Room & $63.1-63.5$ & $62.9-63.6$ & 106 CFM \\
Nook/Kitchen & $63.2-65.5$ & $62.9-65.7$ & 83 CFM \\
Master Bedroom & $63.4-65.1$ & $62.9-65.1$ & 92 CFM \\
Master Bath & $63.1-65.3$ & $62.9-65.5$ & 90 CFM \\
Dining Room & $63.1-63.9$ & $62.9-64.1$ & 193 CFM \\
Return Ducts (Back/Front) & $73.3 / 75.0$ & $75.5 / 75.0$ & \\
Attic/Outside Temperatures & $137.6 / 102.7$ & $138.7 / 103.0$ & \\
Test End Time & $3: 39$ & $3: 47$ & \\
Sum of the supply grille air flow & & & 912 CFM
\end{tabular}

Fan W:

$298 \mathrm{~W}$ (furnace stand-by W 7.2 W, $0.318 \mathrm{~W} / \mathrm{CFM}$ )

Static Pressure:

0.389 in. $(-19.1 \mathrm{~Pa},+78.1 \mathrm{~Pa}$, minimum efficiency filters, two $20 \times 20$ filter grilles, only a $1-1 / 2$-ton cooling coil)

Return Grille Air Flow (cooling, wet coil):

Duct Blaster 937 CFM (625 CFM/ton)

Duct Leakage and Half Nelson:

Total Duct Leakage $\quad 34 \mathrm{CFM}_{25}$

DLO $14.6 \mathrm{CFM}_{25}$ (Ring 4, $184 \mathrm{~Pa}$ )

Half Nelson $\quad-391 \mathrm{~Pa},+110 \mathrm{~Pa}$

House Leakage: $1,435 \mathrm{CFM}_{50}$ 


\section{Appendix E: Additional Modeling Results}

Detailed HVAC source energy use by end use for all cases evaluated is presented in Table 29 through Table 35 for each climate and prototype.

Figure 31 through Figure 35 present BEopt HVAC source energy use and DE for the major cases evaluated in each of the four evaluation climates. 
Table 28. Annual Source HVAC Energy Use for All Cases in Phoenix, 2,100- $\mathrm{ft}^{2}$ Prototype

\begin{tabular}{|c|c|c|c|c|c|c|c|c|c|c|c|c|c|c|}
\hline \multirow[b]{2}{*}{ End Use } & \multicolumn{14}{|c|}{ Source HVAC Energy Use (MMBtu/yr) } \\
\hline & 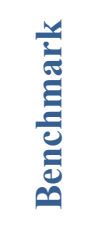 & 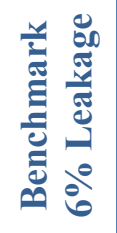 & $\bigcup_{0}^{2}$ & 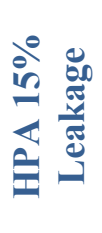 & 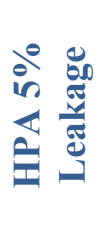 & 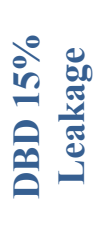 & 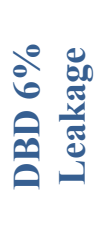 & 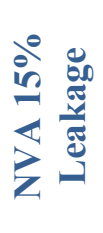 & 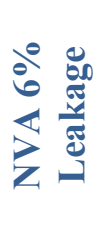 & 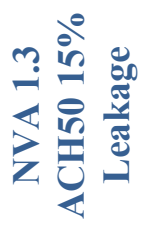 & 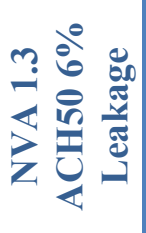 & 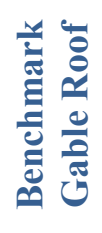 & 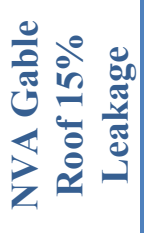 & 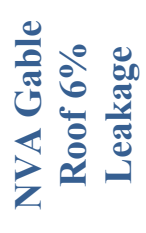 \\
\hline HVAC Fan & 13.29 & 12.28 & 10.53 & 12.02 & 11.19 & 11.91 & 10.90 & 11.69 & 11.54 & 11.42 & 11.24 & 13.36 & 12.32 & 12.15 \\
\hline Cooling & 52.42 & 48.32 & 41.71 & 47.22 & 43.97 & 47.00 & 43.12 & 45.77 & 45.27 & 45.04 & 44.41 & 52.64 & 48.01 & 47.34 \\
\hline Heating & 5.48 & 5.11 & 4.63 & 5.19 & 4.83 & 4.11 & 3.83 & 4.65 & 4.56 & 4.10 & 3.99 & 5.52 & 6.00 & 5.86 \\
\hline Total & 71.19 & 65.71 & 56.87 & 64.43 & 59.99 & 63.02 & 57.85 & 62.11 & 61.36 & 60.56 & 59.64 & 71.51 & 66.32 & 65.36 \\
\hline
\end{tabular}

Table 29. Annual Source HVAC Energy Use for All Cases in Phoenix, 2,700- $\mathrm{ft}^{2}$ Prototype

\begin{tabular}{|c|c|c|c|c|c|c|c|c|c|c|c|c|c|c|}
\hline \multirow[b]{2}{*}{ End Use } & \multicolumn{14}{|c|}{ Source HVAC Energy Use (MMBtu/yr) } \\
\hline & 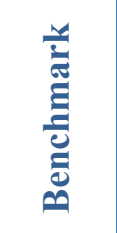 & 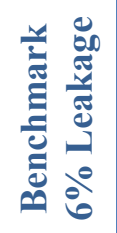 & $\underbrace{\infty}_{0}$ & 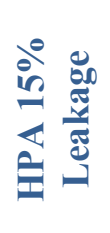 & 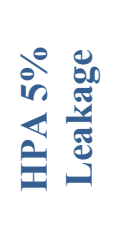 & 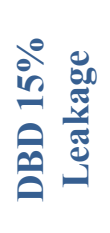 & 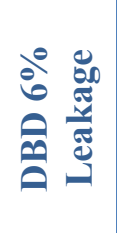 & 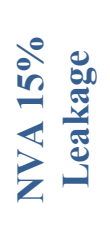 & 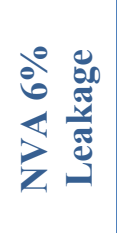 & 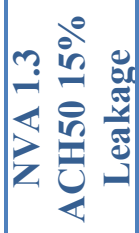 & 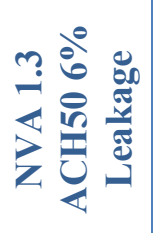 & 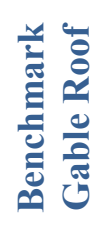 & 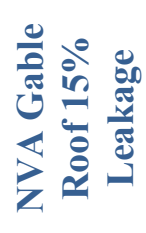 & 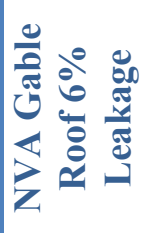 \\
\hline HVAC Fan & 16.90 & 15.87 & 14.36 & 15.74 & 14.95 & 15.90 & 14.87 & 14.93 & 14.85 & 14.20 & 14.10 & 17.07 & 15.39 & 15.27 \\
\hline Cooling & 65.52 & 61.46 & 55.47 & 60.70 & 57.71 & 61.74 & 57.64 & 57.64 & 57.27 & 55.25 & 54.72 & 66.12 & 59.19 & 58.75 \\
\hline Heating & 10.49 & 9.97 & 9.34 & 10.22 & 9.71 & 9.43 & 8.94 & 9.31 & 9.21 & 7.35 & 7.25 & 10.47 & 10.00 & 9.89 \\
\hline Total & 92.91 & 87.30 & 79.17 & 86.66 & 82.37 & 87.07 & 81.45 & 81.88 & 81.33 & 76.80 & 76.06 & 93.66 & 84.57 & 83.90 \\
\hline
\end{tabular}


Table 30. Annual Source HVAC Energy Use for All Cases in Fresno, 2,100- $\mathrm{ft}^{2}$ Prototype

\begin{tabular}{|c|c|c|c|c|c|c|c|c|c|c|c|c|c|c|}
\hline \multirow[b]{2}{*}{ End Use } & \multicolumn{14}{|c|}{ Source HVAC Energy Use (MMBtu/yr) } \\
\hline & 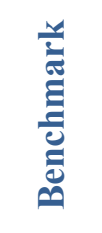 & 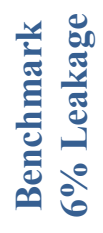 & $U^{n}$ & 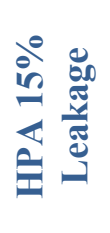 & 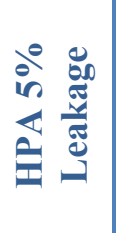 & 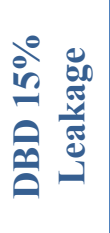 & 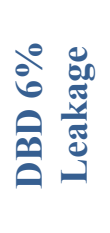 & 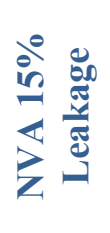 & 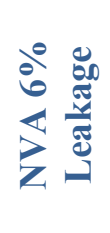 & 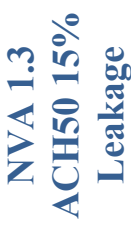 & 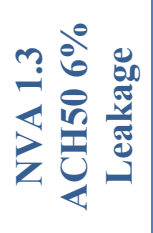 & 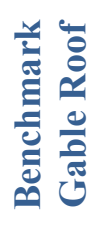 & 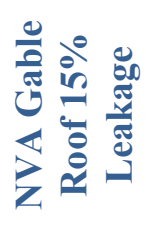 & 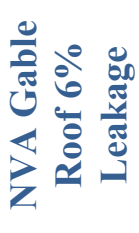 \\
\hline HVAC Fan & 7.29 & 6.78 & 5.88 & 6.49 & 6.08 & 6.32 & 5.86 & 6.57 & 6.48 & 6.35 & 6.25 & 7.33 & 7.05 & 6.93 \\
\hline Cooling & 19.75 & 18.27 & 15.66 & 16.79 & 15.62 & 17.01 & 15.66 & 17.48 & 17.20 & 17.23 & 16.92 & 19.94 & 18.21 & 17.86 \\
\hline Heating & 26.61 & 24.92 & 22.46 & 26.38 & 24.59 & 23.22 & 21.66 & 23.81 & 23.52 & 22.14 & 21.79 & 26.62 & 27.20 & 26.81 \\
\hline Total & 53.65 & 49.97 & 44.00 & 49.66 & 46.29 & 46.55 & 43.17 & 47.86 & 47.20 & 45.72 & 44.95 & 53.89 & 52.45 & 51.60 \\
\hline
\end{tabular}

Table 31. Annual Source HVAC Energy Use for All Cases in Fresno, 2,700- $\mathrm{ft}^{2}$ Prototype

\begin{tabular}{|c|c|c|c|c|c|c|c|c|c|c|c|c|c|c|}
\hline \multirow[b]{2}{*}{ End Use } & \multicolumn{14}{|c|}{ Source HVAC Energy Use (MMBtu/yr) } \\
\hline & 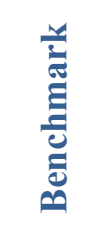 & 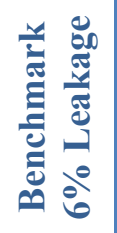 & $\bigcup_{0}^{\infty}$ & 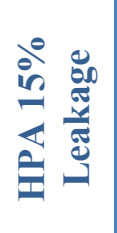 & 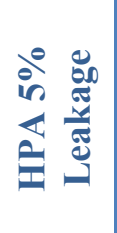 & 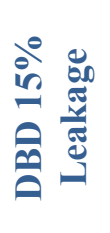 & 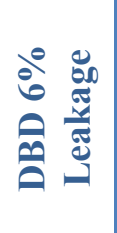 & 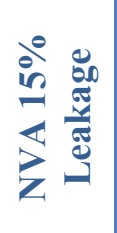 & 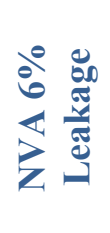 & 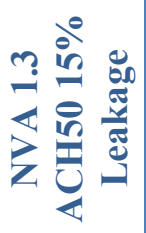 & 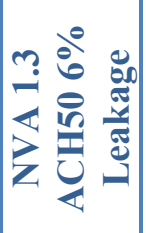 & 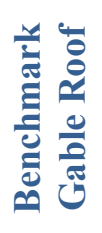 & 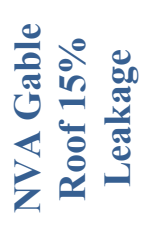 & 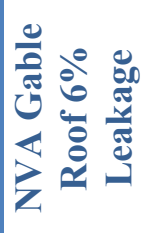 \\
\hline HVAC Fan & 9.86 & 9.34 & 8.51 & 9.15 & 8.75 & 9.17 & 8.65 & 8.90 & 8.81 & 8.30 & 8.19 & 9.99 & 9.19 & 9.10 \\
\hline Cooling & 26.11 & 24.57 & 22.18 & 23.56 & 22.40 & 24.19 & 22.68 & 23.09 & 22.87 & 22.43 & 22.18 & 26.55 & 23.78 & 23.50 \\
\hline Heating & 37.23 & 35.47 & 33.11 & 36.89 & 35.05 & 34.85 & 33.09 & 33.80 & 33.58 & 28.49 & 28.22 & 37.14 & 35.34 & 35.07 \\
\hline Total & 73.21 & 69.38 & 63.80 & 69.60 & 66.20 & 68.21 & 64.42 & 65.79 & 65.26 & 59.22 & 58.59 & 73.68 & 68.31 & 67.66 \\
\hline
\end{tabular}


Table 32. Annual Source HVAC Energy Use for All Cases in Sacramento, 2,100-ft ${ }^{2}$ Prototype

\begin{tabular}{|c|c|c|c|c|c|c|c|c|c|c|c|c|c|c|}
\hline \multirow[b]{2}{*}{ End Use } & \multicolumn{14}{|c|}{ Source HVAC Energy Use (MMBtu/yr) } \\
\hline & 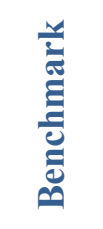 & 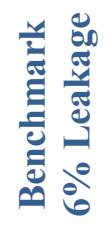 & $\underbrace{\infty}_{0}$ & 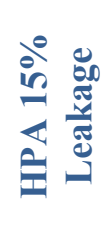 & 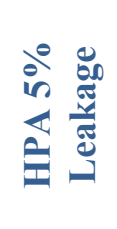 & 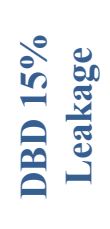 & 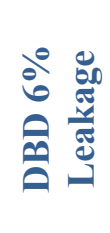 & 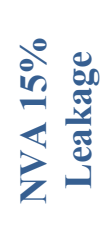 & 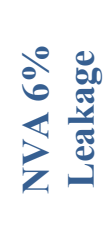 & 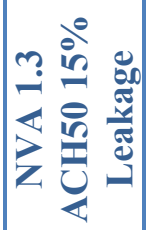 & 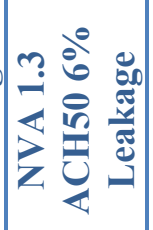 & 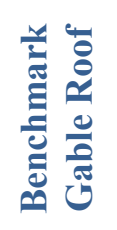 & 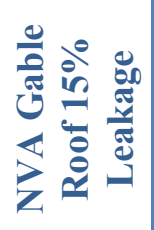 & 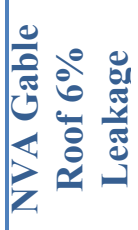 \\
\hline HVAC Fan & 4.66 & 4.40 & 3.85 & 4.15 & 3.88 & 3.96 & 3.68 & 4.13 & 4.07 & 3.97 & 3.89 & 4.72 & 4.49 & 4.43 \\
\hline Cooling & 7.84 & 7.24 & 6.21 & 5.99 & 5.58 & 6.30 & 5.83 & 6.68 & 6.52 & 6.58 & 6.43 & 8.00 & 6.87 & 6.68 \\
\hline Heating & 33.81 & 31.68 & 28.49 & 33.55 & 31.29 & 29.68 & 27.71 & 30.01 & 29.65 & 27.98 & 27.54 & 33.81 & 34.00 & 33.51 \\
\hline Total & 46.32 & 43.32 & 38.55 & 43.69 & 40.75 & 39.94 & 37.22 & 40.82 & 40.24 & 38.53 & 37.86 & 46.53 & 45.35 & 44.61 \\
\hline
\end{tabular}

Table 33. Annual Source HVAC Energy Use for All Cases in Sacramento, 2,700- $\mathrm{ft}^{2}$ Prototype

\begin{tabular}{|c|c|c|c|c|c|c|c|c|c|c|c|c|c|c|}
\hline \multirow[b]{2}{*}{ End Use } & \multicolumn{14}{|c|}{ Source HVAC Energy Use (MMBtu/yr) } \\
\hline & 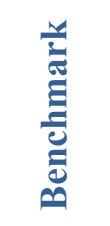 & 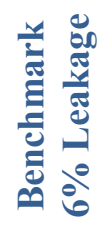 & Ũ & 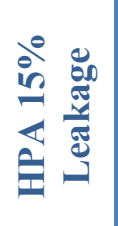 & 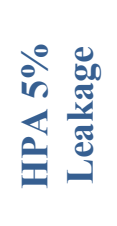 & 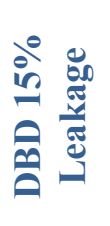 & 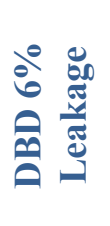 & 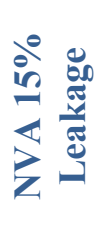 & 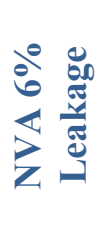 & 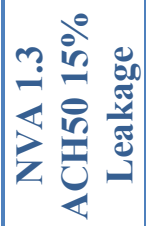 & 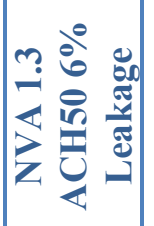 & 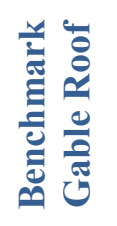 & 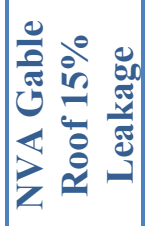 & 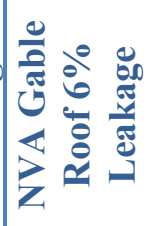 \\
\hline HVAC Fan & 6.53 & 6.24 & 5.74 & 6.06 & 5.83 & 6.00 & 5.72 & 5.87 & 5.80 & 5.36 & 5.30 & 6.62 & 6.11 & 6.05 \\
\hline Cooling & 11.21 & 10.55 & 9.51 & 9.73 & 9.23 & 10.17 & 9.54 & 9.73 & 9.61 & 9.58 & 9.42 & 11.56 & 10.05 & 9.89 \\
\hline Heating & 45.56 & 43.41 & 40.48 & 45.16 & 42.92 & 42.65 & 40.52 & 41.22 & 40.94 & 34.87 & 34.54 & 45.42 & 43.02 & 42.67 \\
\hline Total & 63.31 & 60.21 & 55.74 & 60.95 & 57.98 & 58.83 & 55.78 & 56.83 & 56.35 & 49.81 & 49.26 & 63.60 & 59.18 & 58.61 \\
\hline
\end{tabular}


Table 34. Annual Source HVAC Energy Use for All Cases in Albuquerque, 2,100- $\mathrm{ft}^{2}$ Prototype

\begin{tabular}{|c|c|c|c|c|c|c|c|c|c|c|c|c|c|c|}
\hline \multirow[b]{2}{*}{ End Use } & \multicolumn{14}{|c|}{ Source HVAC Energy Use (MMBtu/yr) } \\
\hline & 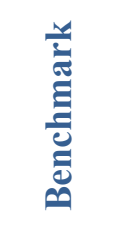 & 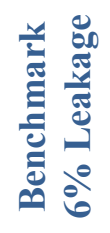 & $\bigcup_{0}^{\infty}$ & 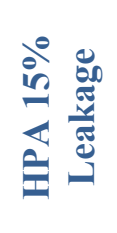 & 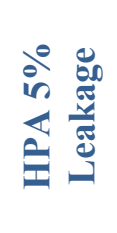 & 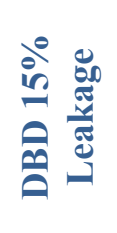 & 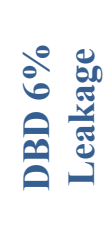 & 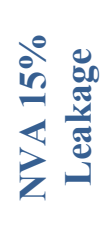 & 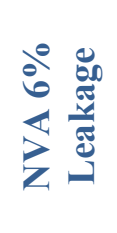 & 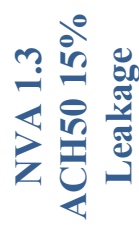 & 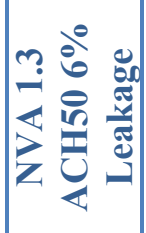 & 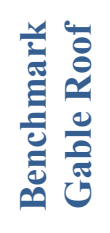 & 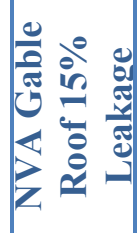 & 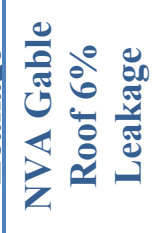 \\
\hline HVAC Fan & 7.34 & 6.91 & 6.04 & 6.77 & 6.37 & 6.30 & 5.93 & 6.67 & 6.55 & 6.32 & 6.21 & 7.35 & 7.25 & 7.12 \\
\hline Cooling & 8.60 & 7.94 & 6.68 & 6.74 & 6.27 & 6.99 & 6.43 & 7.62 & 7.50 & 7.50 & 7.34 & 8.76 & 7.94 & 7.78 \\
\hline Heating & 52.01 & 48.70 & 42.85 & 52.19 & 48.65 & 46.16 & 43.06 & 45.53 & 45.16 & 42.48 & 41.90 & 52.03 & 51.13 & 50.59 \\
\hline Total & 67.95 & 63.55 & 55.57 & 65.70 & 61.29 & 59.45 & 55.41 & 59.82 & 59.21 & 56.29 & 55.45 & 68.13 & 66.32 & 65.49 \\
\hline
\end{tabular}

Table 35. Annual Source HVAC Energy Use for All Cases in Albuquerque, 2,700-ft ${ }^{2}$ Prototype

\begin{tabular}{|c|c|c|c|c|c|c|c|c|c|c|c|c|c|c|}
\hline \multirow[b]{2}{*}{ End Use } & \multicolumn{14}{|c|}{ Source HVAC Energy Use (MMBtu/yr) } \\
\hline & 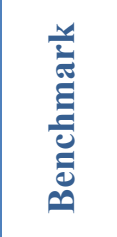 & 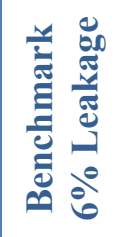 & Ũ & 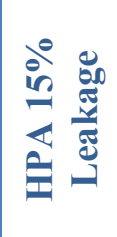 & 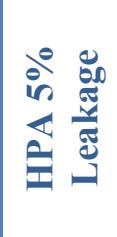 & 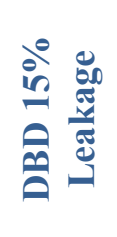 & 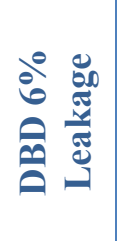 & 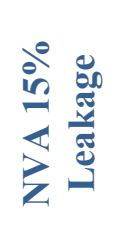 & 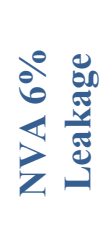 & 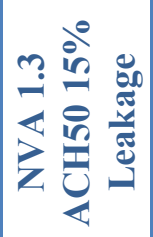 & 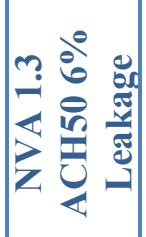 & 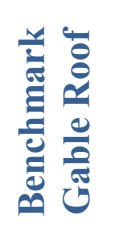 & 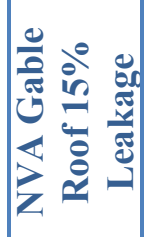 & 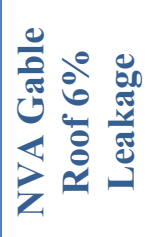 \\
\hline HVAC Fan & 10.15 & 9.70 & 8.97 & 9.62 & 9.25 & 9.43 & 0.77 & 9.27 & 9.19 & 8.31 & 8.24 & 10.24 & 9.62 & 9.54 \\
\hline Cooling & 12.66 & 11.94 & 10.65 & 11.09 & 10.52 & 11.50 & 10.80 & 11.15 & 11.02 & 10.90 & 10.74 & 13.01 & 11.53 & 11.37 \\
\hline Heating & 68.90 & 65.57 & 60.24 & 68.59 & 65.14 & 64.67 & 61.35 & 61.61 & 61.33 & 52.18 & 51.75 & 68.70 & 64.12 & 63.77 \\
\hline Total & 91.71 & \begin{tabular}{|l|}
87.21 \\
\end{tabular} & \begin{tabular}{|l|}
79.86 \\
\end{tabular} & 89.30 & 84.91 & 85.60 & 81.14 & 82.03 & 81.55 & 71.39 & 70.73 & 91.95 & 85.27 & 84.68 \\
\hline
\end{tabular}



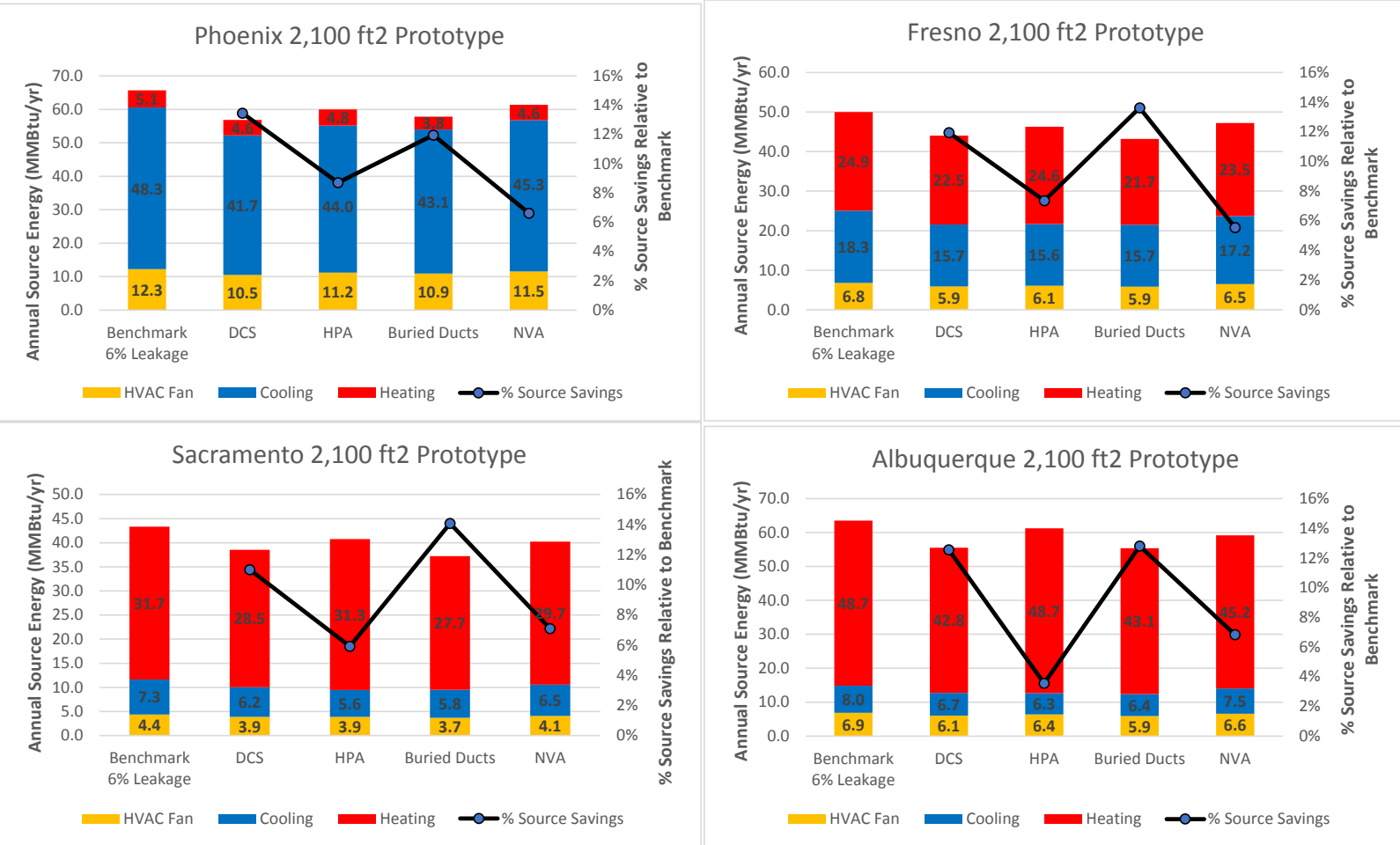

Figure 31. Annual HVAC source energy use comparison by climate for $2,100-\mathrm{ft}^{2}$ prototype
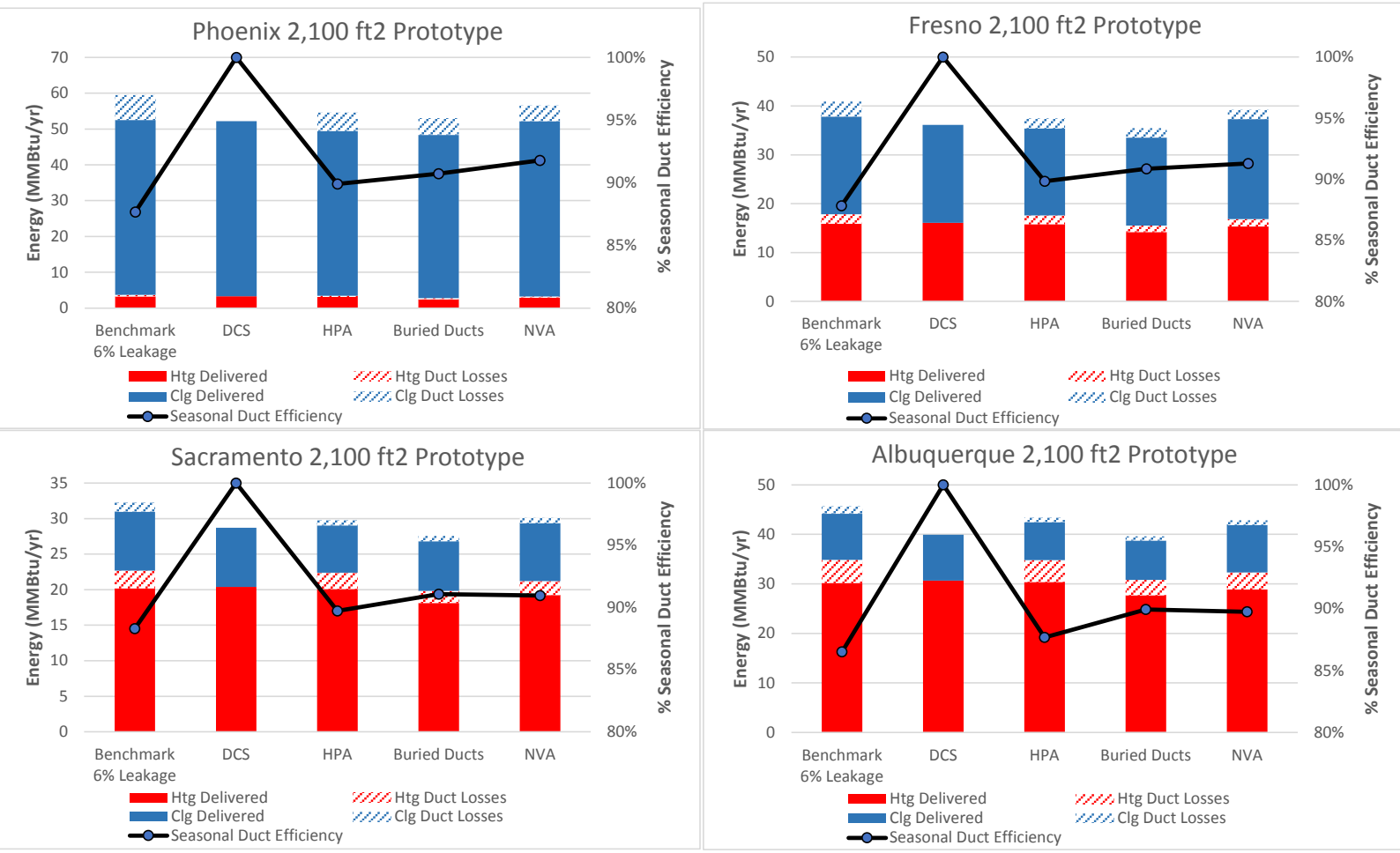

Figure 32. Distribution effectiveness comparison by climate for $2,100-\mathrm{ft}^{2}$ prototype 

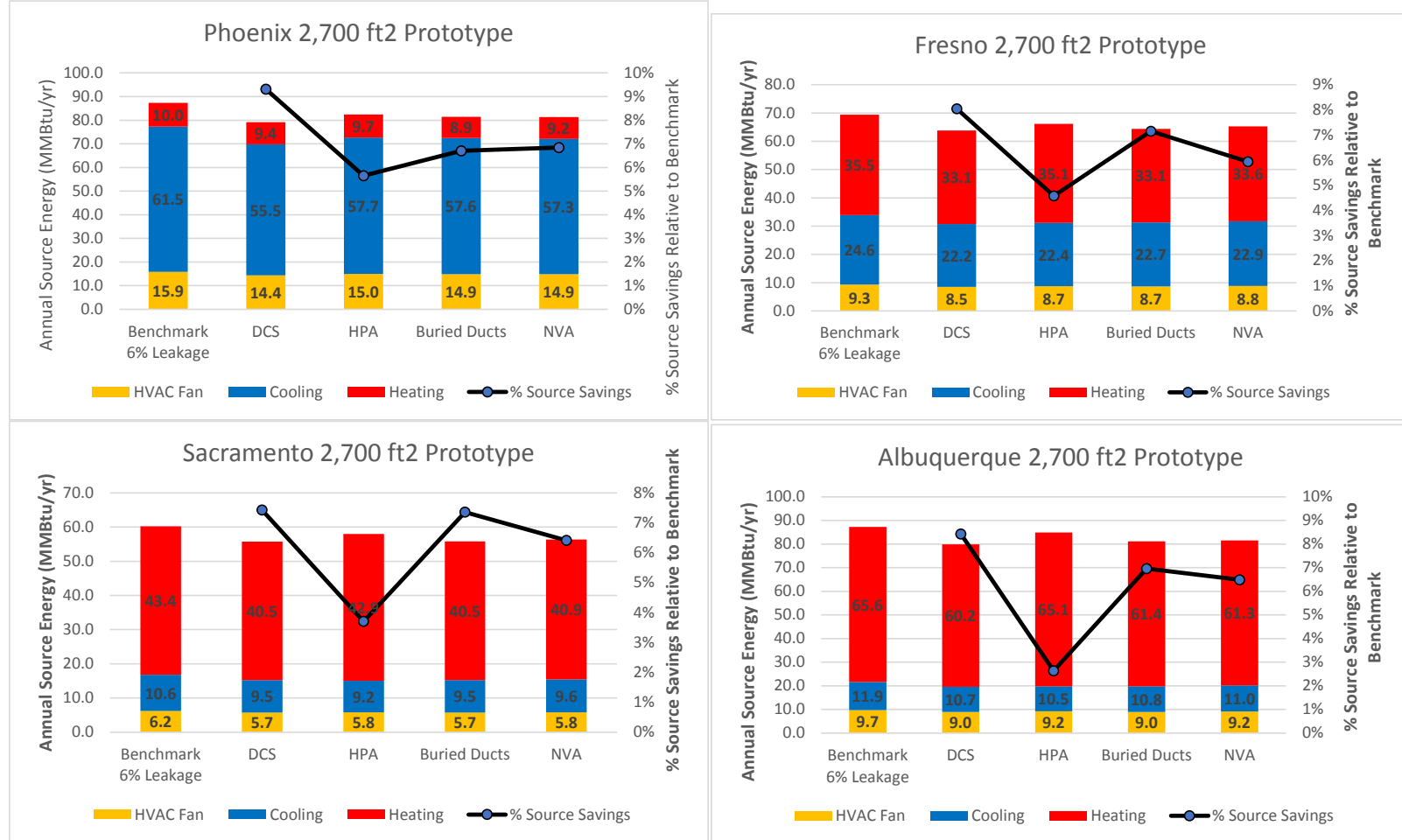

Figure 33. Annual HVAC source energy use comparison by climate for $2,700-\mathrm{ft}^{2}$ prototype
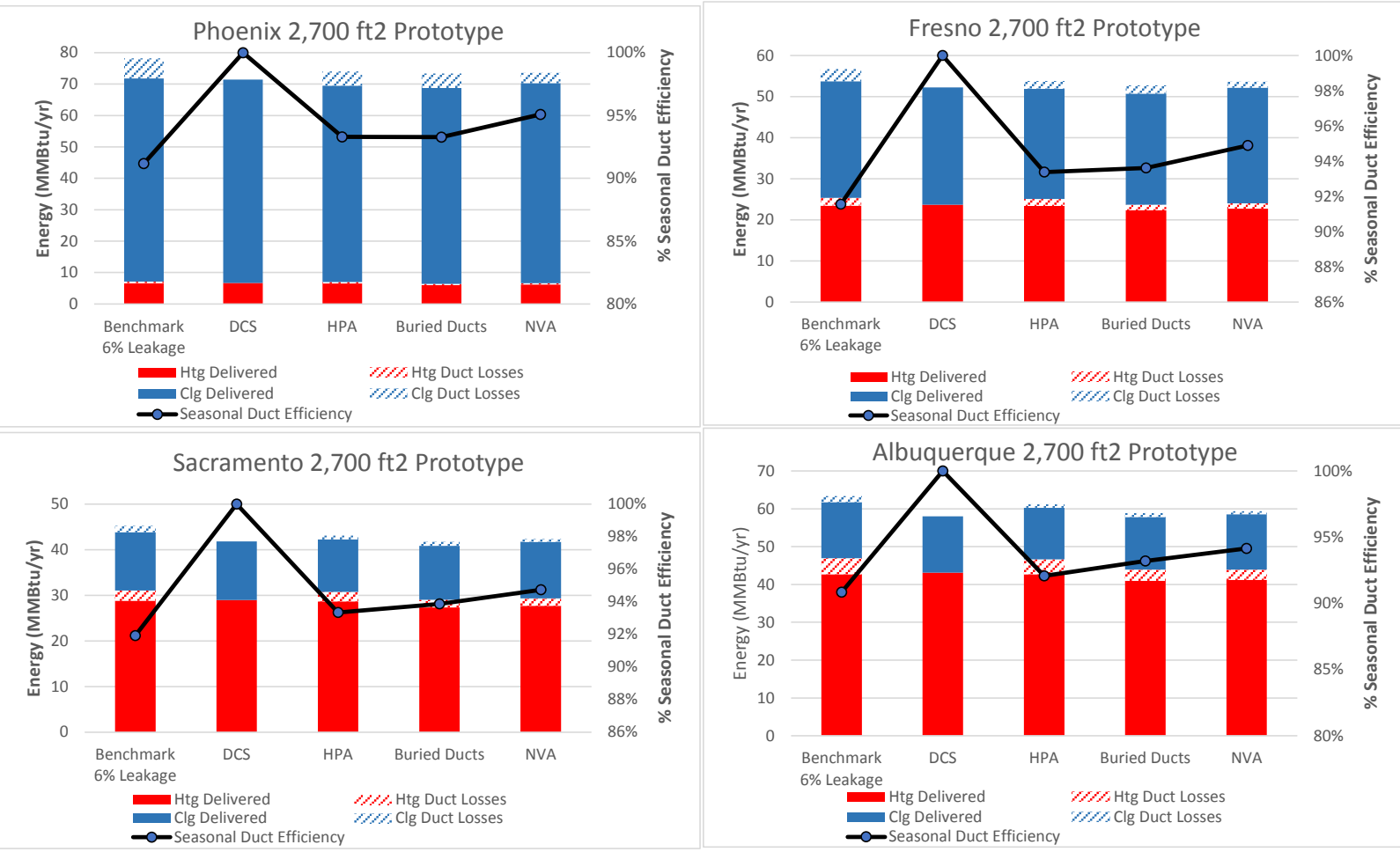

Figure 34. Distribution effectiveness comparison by climate for $2,700-\mathrm{ft}^{2}$ prototype 
buildingamerica.gov

U.S. DEPARTMENT OF Energy Efficiency \&

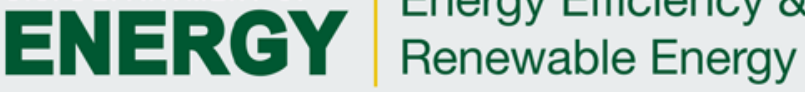

